\title{
Paleoenvironmental analysis of early Eocene marl and limestone alternations from Mead Stream, New Zealand
}

by

Sonja Peñafiel Bermudez

A thesis submitted to Victoria University of Wellington in fulfilment of the requirements for the degree of Master of Science in Geology

Victoria University of Wellington 


\section{For Crusoe}

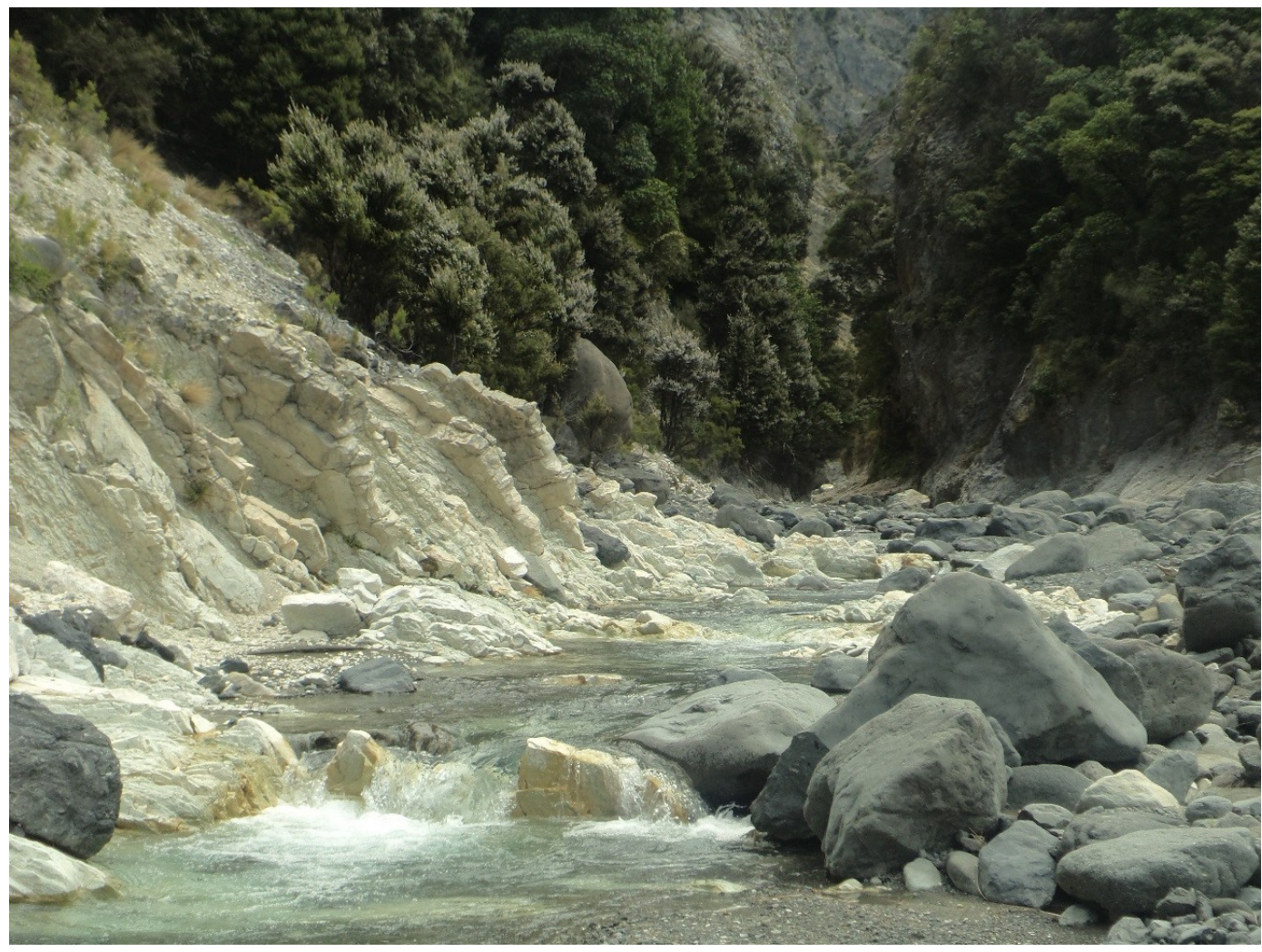

"There is a way that nature speaks, that land speaks. Most of the time we are simply not patient enough, quiet enough, to pay attention to the story." - Linda Hogan 


\section{ABSTRACT}

This study integrates paleonotology and geochemistry to provide a paleoclimatic analysis of cyclic sedimentation in the Lower Marl at Mead Stream in Marlborough, Aotearoa/New Zealand. The alternating marl and limestone bedding in this outcrop coincide with the warmest period in the Paleogene, the Early Eocene Climatic Optimum (EECO).

An acetic acid leaching method was refined and used successfully to extract microfossils from the indurated limestones and marls from two intervals of the Lower Marl. The technique resulted in foraminiferal tests with improved surface ornament in comparison with samples that were processed using standard washing methodology.

The resulting paleontological assessment of leached foraminiferal and radiolarian assemblages coupled with XRF and stable isotope analysis revised the position and detailed the faunal response to the J hyperthermal at the initiation of the EECO. Microfossil assemblages and carbon isotopic data suggest that the $J$ carbon isotopic excursion (CIE) may be a two-stage event. A new L-3 CIE and possible hyperthermal event was identified within the body of the EECO. Both the J and L-3 events contained acmes where Morozovella made up a quarter of the planktic foraminiferal specimens, suggesting the southern expansion of subtropical waters. Fluctuations of Acarinina and Subbotina foraminifera coinciding with the marl and limestone alternations may indicate climate cycles within these hyperthermals. 


\section{ACKNOWLEDGMENTS}

Firstly, I would like to thank my supervisors for their guidance and patience: Dr Chris Hollis for suggesting this project in the first place, three long summers ago, and providing me with the opportunity of researching this spectacular part of the planet. Your ideas, knowledge and feedback I appreciate. Professor Mike Hannah for all your calming review sessions, and advice on scientific writing and trust that I was on the right track. Thank you to the Murray Family for field access on our two sample collection excursions in the Clarence Valley.

Furthermore, thanks to Emeritus Scientist Percy Strong, an invaluable mentor with his knowledge of Eocene foraminifera and assistance in microfossil identifications throughout.

Additional advice on foraminifera from Hugh Morgans, George Scott and Martin Crundwell was appreciated. Chris Clowes, Joe Prebble and James Crampton, thank you for listening to thoughts and ideas and questions and providing feedback on a plethora of topics. Also, a shout out to Andy Phillips and his team for isotopic analysis.

Thomas Cooper - what a great adventure we have had at Mead Stream - your help with my nemesis ' $R$ ' has not gone unnoticed and our chats have been fantastic - I look forward to us publishing some work together. Marianna Terezow, Henry Gard, Kristina Pascher, Ben Durrant and Ben Hines - cheers for your understanding and answering a million 'thesis' related questions, or just having a laugh together when I needed it. Roger Tremain, Lizette Reyes and Xun Li for your friendships and Ichiban lunches. Claire Shepherd, \#1 officemate and waiata buddy - I appreciate the hoop-shooting and your understanding of the ups and downs and assisting with CorelDraw tricks of the trade. The USSP (Urbino) crew from Café \#12 - Tiah Penny, Stef Mellons and Gabriella Kitch - you may be far away but I have felt your moral support throughout.

And lastly but not least - gratitude to my whanau; Mum and Dad for the extra dog-sitting, veggie soups and just for being there. Lara and fam for putting up with an absent sister and Aunty. To my canine study buddies Crusoe and Zena - thank you for your late-night office company and microscope observance duties around the clock. Tania my love - your unwavering support over the last few years has been key to my completion. Your tolerance of having no weekends together, coming up to the lab all hours of the night and day, hosting the microscope at home and coping with a grumpy wife, has produced few complaints. I promise that our motorbike adventures are within sight! 


\section{TABLE OF CONTENTS}

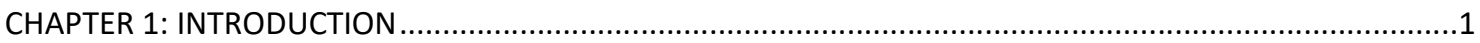

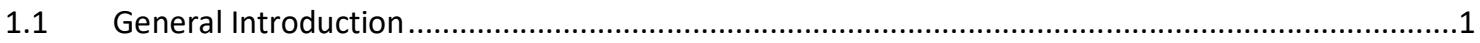

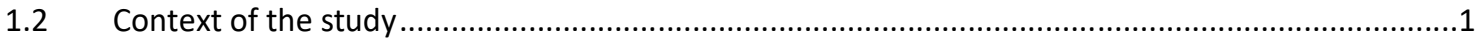

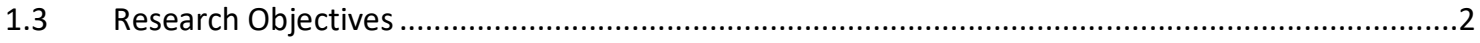

CHAPTER 2: GEOLOGICAL SETTING of the MEAD STREAM section ............................................................

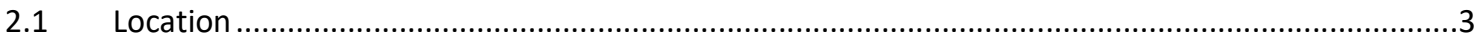

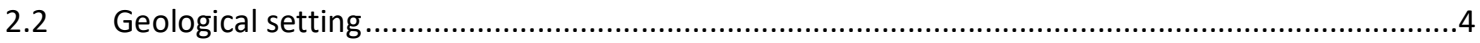

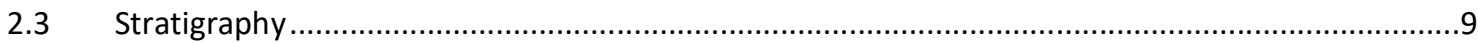

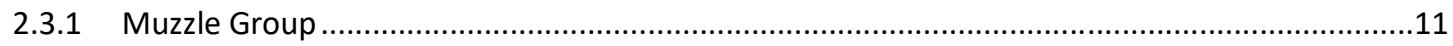

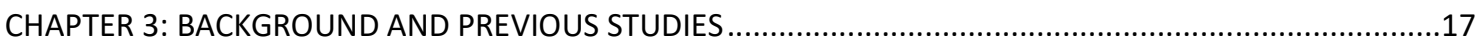

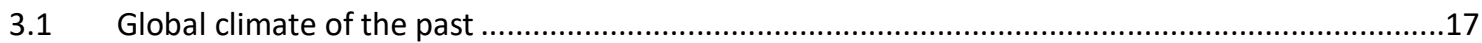

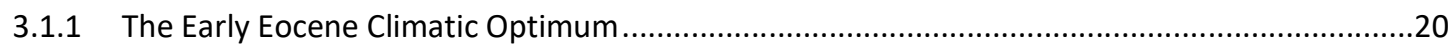

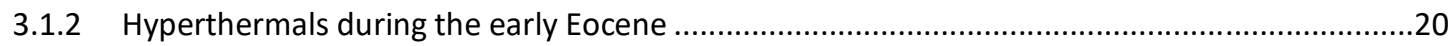

3.1.3 Early Eocene temperature reconstruction in the SW Pacific ......................................................23

3.2 Paleontology

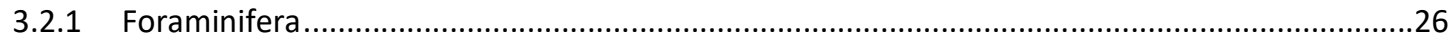

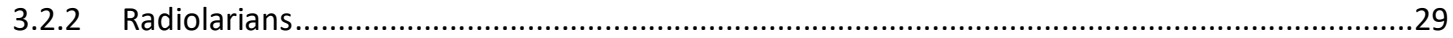

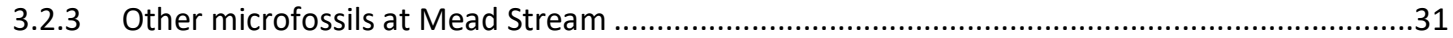

3.3 Depositional setting of Mead Stream ………...............................................................................32

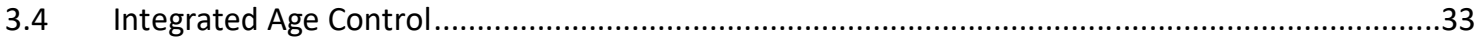

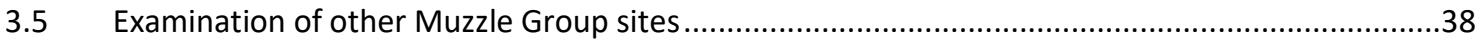

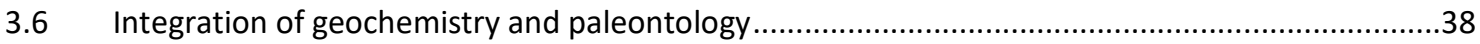

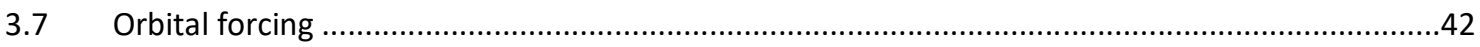

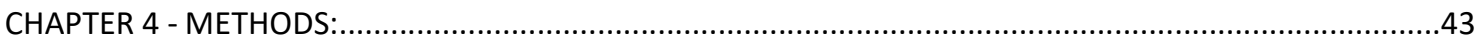

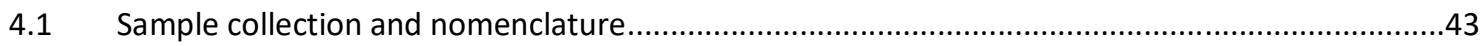

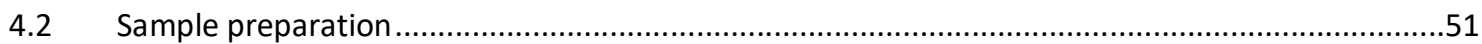

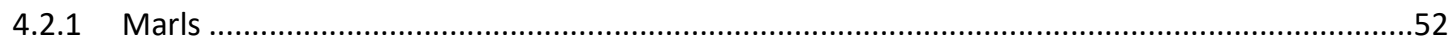

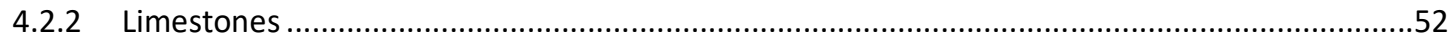

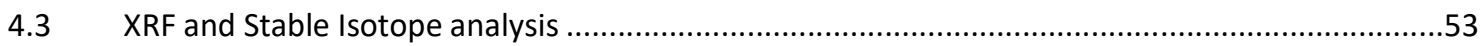

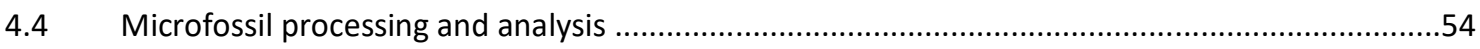

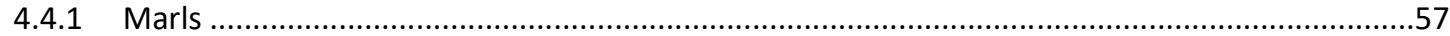




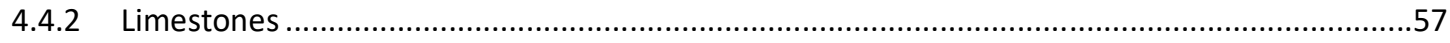

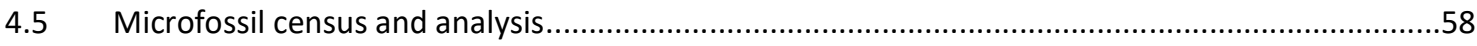

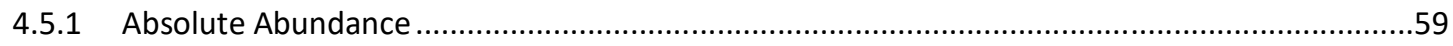

CHAPTER 5: RESULTS - ACETIC ACID-PROCESSING METHOD ......................................................60

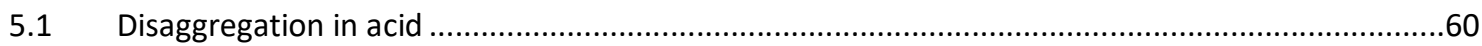

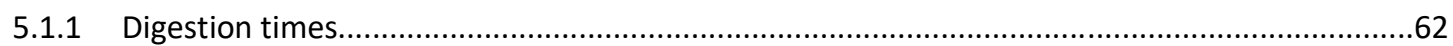

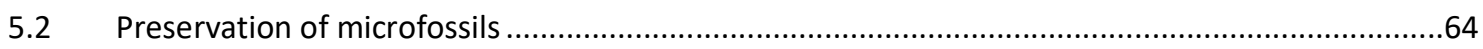

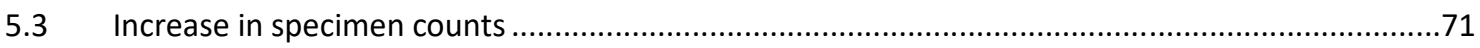

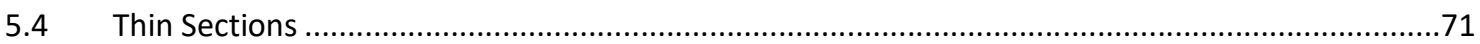

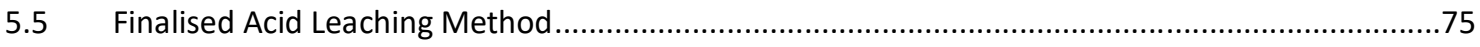

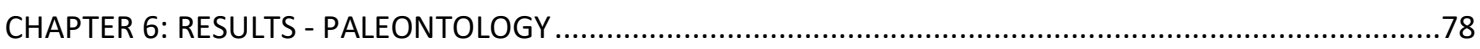

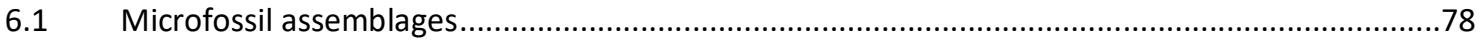

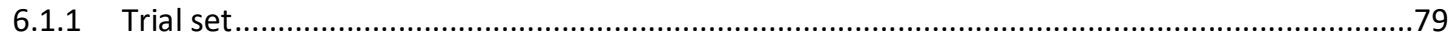

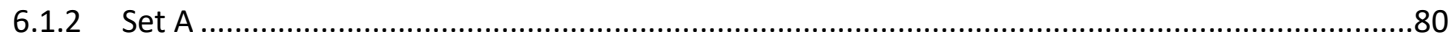

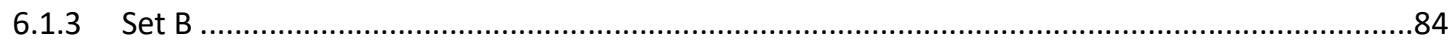

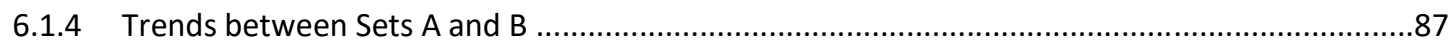

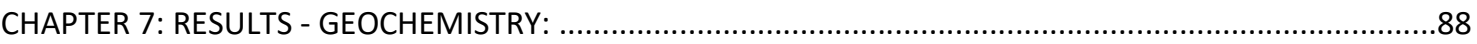

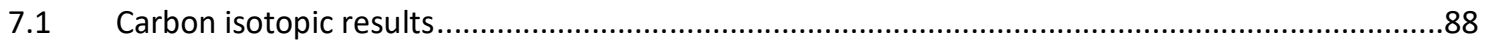

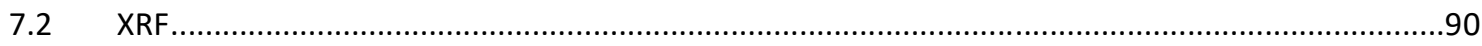

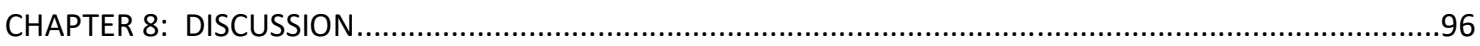

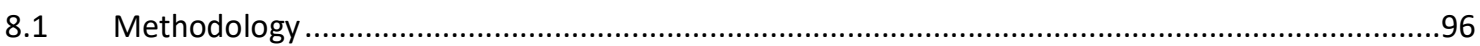

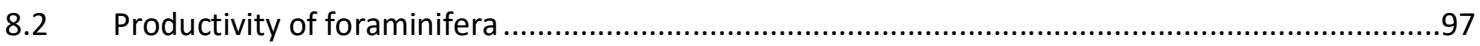

8.3 Multiproxy approach to examining the local expression of the EECO and hyperthermals ............98

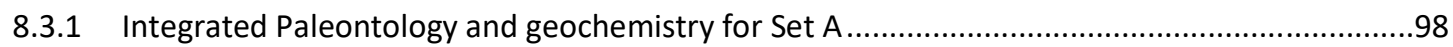

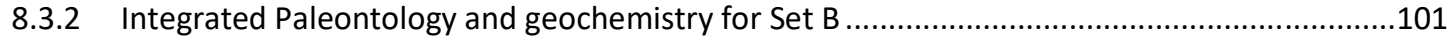

8.4 Paleoclimatic insights into marl and limestone alternations in the Lower Marl........................102

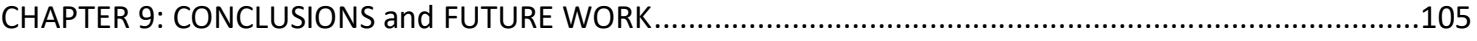

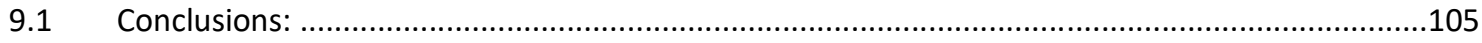

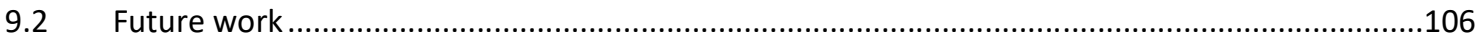

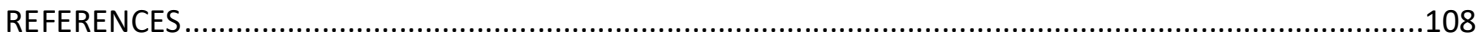

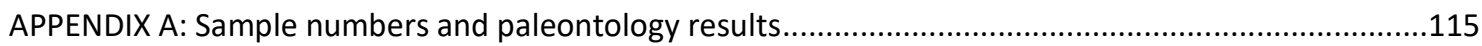

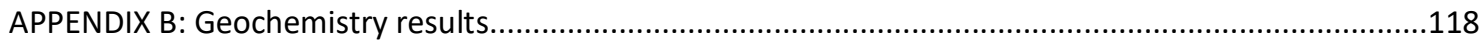

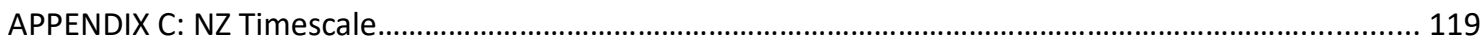




\section{LIST OF FIGURES}

\section{CHAPTER 2: GEOLOGICAL SETTING of the MEAD STREAM section}

2.1 Chaytors Saddle, looking South over the Clarence range with the Mead Stream section in the distance.

2.2 Ariel view of Mead Stream, Clarence Valley before (A) and after (B) the Kaikoura earthquake.

2.3 The Mead Stream section from upper Cretaceous to lower Eocene showing nearby faults.

2.4 Position of the Mead Stream study area during the early Eocene, after northward drift.

2.5 Palinspastic maps indicating the location of the Mead Stream study area at approximately $65 \mathrm{Ma}$.

2.6 Simplified lithostratigraphy illustrating the major units identified in south-eastern Marlborough from the Late Cretaceous to early Oligocene.

2.7 Muzzle group strata showing the stratigraphy in the Clarence Valley.

2.8 Alternating marl and limestone beds within the Lower Marl at Mead Stream

\section{CHAPTER 3: BACKGROUND AND PREVIOUS STUDIES}

3.1 Deep-sea benthic foraminifera oxygen isotope curve including estimated SSTs for the Cenozoic.

3.2 Estimated sea temperature and climate for the NZ region 60-40 Ma.

3.3 Spinose wall texture of foraminifera

3.4 Lithological and geochemical reconstruction of early Eocene conditions at Mead Stream.

3.5 Upper Paleocene-lower Eocene biostratigraphy at Mead Stream spanning 100-250 m above the $\mathrm{K} / \mathrm{Pg}$ boundary.

3.6 Age-Depth Model for Mead Stream including microfossil biohorizons.

3.7 Microfossil zones, lithostratigraphy and carbon isotopes from 100-325 m of the Mead Stream section.

3.8 Variation in bed thickness in Lower Limestone of Mead Stream associated with Milankovitch cycles

CHAPTER 4 - METHODS:

4.1 Lower Marl of the Amuri Limestone of Mead Stream, showing the position of the Trial, A and B sample sets within the section.

4.2 Trial Set samples from 217.52-226.41 m of the Lower Marl at Mead Stream.

4.3 Limestone and marl beds from 204.72-207.90 m (sub-beds L0-L5) in the Lower Marl, Mead Stream.

4.4 Set A samples from 204.72-207.90 m (LO/1-L5/5) of the Lower Marl at Mead Stream.

4.5 Limestone and marl beds of Set B spanning 251.57-254.64 m (sub-beds L44-L47) in the Lower Marl, Mead Stream.

4.6 Set B samples from 252.09-254.64 m (L44/1-L47/3) of the Lower Marl at Mead Stream.

4.7 Cutting beds L44-L47 of the Lower Marl Amuri Limestone using the rock saw, Mead Stream.

4.8 Samples of the Lower Marl pre-processing.

4.9 Acetic acid method for leaching of limestones. 


\section{CHAPTER 5: RESULTS - ACETIC ACID-PROCESSING METHOD}

5.1 Pre-acid limestone chips with microfossils visible in the matrix (A) from $225.80 \mathrm{~m}$ (L24).

5.2 Pre-acid limestone chips with microfossils visible in the matrix (A) from $205.485 \mathrm{~m}$ (L3/2).

5.3 Photograph of $225.80 \mathrm{~m}$ (L24) limestone chips after acid leaching showing microfossil protruding from the surface (10 times magnification).

5.4 Foraminifera from marls in Lower Marl at Mead Stream at $218.94 \mathrm{~m}$ (L16/M).

5.5 Foraminifera from marls in Lower Marl at Mead Stream at $219.96 \mathrm{~m}$ (L17/M).

5.6 Foraminifera from the limestones adjacent to marls featured in the above plates at 218.28 m (L16).

5.7 Foraminifera from limestones in Lower Marl at Mead Stream - Set A.

5.8 Foraminifera from limestones in Lower Marl at Mead Stream - Set B.

5.9 Comparison of 100 and 300 specimen census of the 13 samples from $206.70 \mathrm{~m}$ to $207.46 \mathrm{~m}$ (L3/5 $\mathrm{L} 4 / \mathrm{M} / 2)$.

5.10 Thin Section from 218.28 m (L16) from the Trial Set of Lower Marl, Mead Stream.

5.11 Thin Section from 219.53 m (L16/M) from the Trial Set of Lower Marl, Mead Stream.

5.12 Thin Section from 220.53 m (L17) from the Trial Set of Lower Marl, Mead Stream.

5.13 Thin Section from 219.96 m (L17/M) from the Trial Set of Lower Marl, Mead Stream

CHAPTER 6: RESULTS - PALEONTOLOGY

6.1 Microfossil assemblages of Set A 204.715-207.900 m (beds L0-L5) spanning 5 limestone and marl alternations.

6.2 Microfossil assemblages of Set B 251.573-254.640 m (beds L44-L47) spanning 4 limestone and 3 marl alternations.

\section{CHAPTER 7: RESULTS - GEOCHEMISTRY}

7.1 Carbon isotope results at Mead Stream spanning 205-260m.

7.2 Lithological bandygrams showing fractions of terrigenous, CaCO3 and Si[ex] across Sets A and B.

7.3 Plots of excess silica versus calcium carbonate content and radiolarian abundance (R/F ratio).

7.4 Reaction times in acetic acid compared with terrigenous content.

\section{CHAPTER 8: DISCUSSION}

8.1 Summary of microfossil populations including dinocyst Homotryblium acmes across the J event.

8.2 Summary of Morozovella populations across the proposed L-3 event.

8.3 Example of Morozovella decline observed at the initiation of the EECO at DSDP low latitudinal Site 577. 


\section{LIST OF TABLES}

\section{CHAPTER 5: RESULTS - ACETIC ACID-PROCESSING METHOD}

5.1 Digestion times of Mead Stream samples in acetic acid for all 3 sets. Marls are highlighted in blue.

5.2 Microfossil content from eight samples of the Trial Set interval (218.28-221.47 m; L16-L19/M) Lower Marl, Mead Stream.

CHAPTER 6: RESULTS - PALEONTOLOGY

6.1 Microfossil assemblages from low resolution samples spanning 217.52 to $226.41 \mathrm{~m}$ (L15-L25) from the Lower Marl at Mead Stream 


\section{ACRONYMS}

\begin{tabular}{|c|c|}
\hline CCD & Carbon Compensation Depth \\
\hline $\mathrm{CIE}$ & Carbon Isotopic Excursion \\
\hline DSDP & Deep Sea Drilling Project \\
\hline EAC & East Australian current \\
\hline EECO & Early Eocene Climatic Optimum \\
\hline ETM & Eocene Thermal Maximum \\
\hline IODP & International Ocean Discovery Programme \\
\hline IPCC & Intergovernmental Panel on Climate Change \\
\hline $\mathrm{K} / \mathrm{Pg}$ & Cretaceous-Paleogene \\
\hline MPE & Marlborough paleo-embayment \\
\hline MS & Magnetostratigraphy \\
\hline NZMG & New Zealand Map Grid \\
\hline ODP & Ocean Drilling Project \\
\hline PETM & Paleocene Eocene Climatic Optimum \\
\hline PPE & Personal Protective Equipment \\
\hline SAR & Sediment Accumulation Rate \\
\hline SEM & Scanning Electron Microscope \\
\hline SST & Sea Surface Temperature \\
\hline TOC & Total Organic Carbon \\
\hline $\mathrm{TEX}_{86}$ & Tetra-ether Index of Carbon 86 atoms \\
\hline XRF & X-ray Fluorescence \\
\hline
\end{tabular}




\section{CHAPTER 1: INTRODUCTION}

\subsection{General Introduction}

The present rate of anthropogenic carbon release is unprecedented in the last 66 million years (Zeebe et al., 2016). In response, average global temperature has risen between 0.4 and $0.8^{\circ} \mathrm{C}$ over the past century (Hansen et al., 2006). The Intergovernmental Panel on Climate Change (IPCC) Fifth Assessment Report (Pachauri et al., 2014) predicted that these temperatures could further increase between 1.4 and $5.8^{\circ} \mathrm{C}$ by the year 2100 . Paleoclimate science can provide analysis of environmental conditions in response to pre-industrial carbon emissions and therefore provide parameters for models to predict these future scenarios. Paleoclimatic studies also foster understanding of the consequences of carbon dioxide $\left(\mathrm{CO}_{2}\right)$ input on long term geological time scales (Zeebe \& Zachos, 2013).

When examining projected levels of $\mathrm{CO}_{2}$ until the year 2400, it was found that the early Eocene had the most comparable levels of $\mathrm{CO}_{2}(>1800$ parts per million $(\mathrm{ppm}))$ recorded in geological history (Zachos et al., 2008). Therefore, studying the early Paleogene is of relevance today as we look to a predicted future of comparable levels of warming and carbon input into the ocean and atmosphere (Bowen et al., 2006; Mclnerney \& Wing, 2011; Zeebe \& Zachos, 2013).

\subsection{Context of the study}

This thesis is a high-resolution microfossil study which aims to contribute to the understanding of warming events during the early Eocene. The research details foraminiferal assemblages from the Mead Stream section in Marlborough, Aotearoa/New Zealand, with a focus on the alternating marls and limestones that occur within the interval correlated with the Early Eocene Climatic Optimum (EECO), 53-49 million years ago (Ma). Previous studies of microfossils from Mead Stream, particularly foraminifera, have been hindered by the inability to extract calcareous microfossils from the hard limestone beds. 
This has limited biostratigraphic resolution and paleoenvironmental analysis. Thus, a significant component of this project is refining laboratory techniques for leaching limestones with acid to remove foraminifera for analysis. The resulting paleontological data has been combined with elemental geochemistry to provide paleoenvironmental interpretation of the alternating marls and limestones and to determine whether they represent climate cycles.

\subsection{Research Objectives}

1. Refine an acetic acid method in the laboratory to extract foraminifera from limestones of the Lower Marl at Mead Stream.

2. Improve the biostratigraphic definition of the EECO by pinpointing key foraminiferal events.

3. Improve the understanding of how the EECO and associated hyperthermals at Mead Stream affected marine plankton communities, particularly foraminifera.

4. Determine if the limestone/marl alternations within the EECO at Mead Stream represent climate cycles. 


\section{CHAPTER 2: GEOLOGICAL SETTING of the MEAD STREAM section}

\section{$2.1 \quad$ Location}

Mead Stream is located on Bluff Station in the Clarence Valley, New Zealand $\left(173.79^{\circ} \mathrm{E}, 41.96^{\circ} \mathrm{S}\right.$ - Figure 2.1$)$. Historically, this section was accessible from the main road at Kekerengu, Marlborough via private farmland. It was a two-hour journey on a four-wheel drive track and required access permission from land owners. The base of the section was a further 1 kilometre journey on foot through bush and farmland (Figure 2.2).

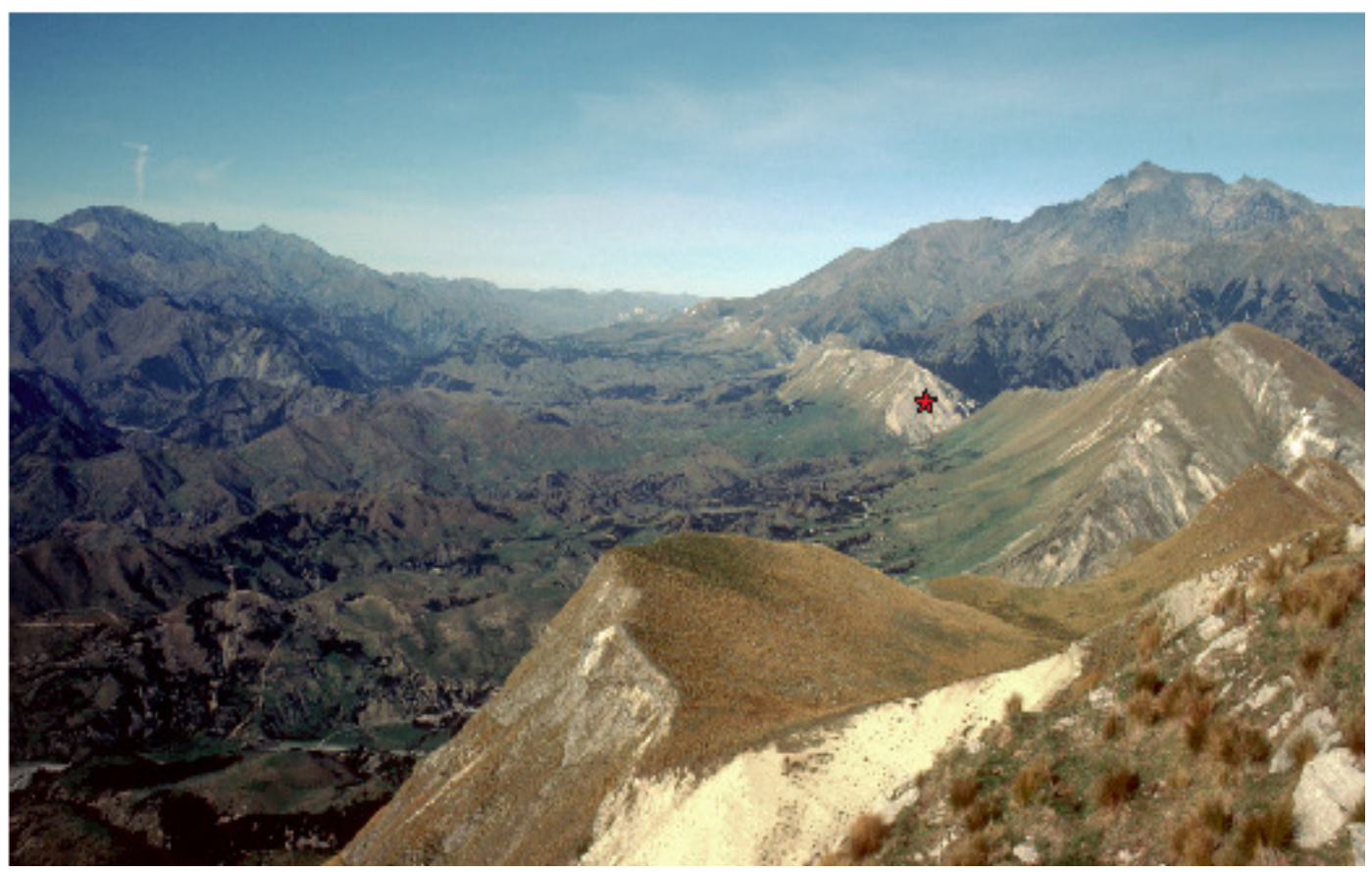

Figure 2.1: Chaytors Saddle, looking South over the Clarence range with the Mead Stream section (red star) in the distance (Photo: J. Crampton, 2008).

The magnitude 7.8 earthquake on 14 November 2016. (the 'Kaikoura earthquake') caused a rupture along the Kekerengu Fault which caused substantial amounts of scree to cascade into Mead Stream and cover most of the section (Figure 2.2). The section is currently inaccessible for further sampling. 
This content is unavailable.

Please consult the print version for access.

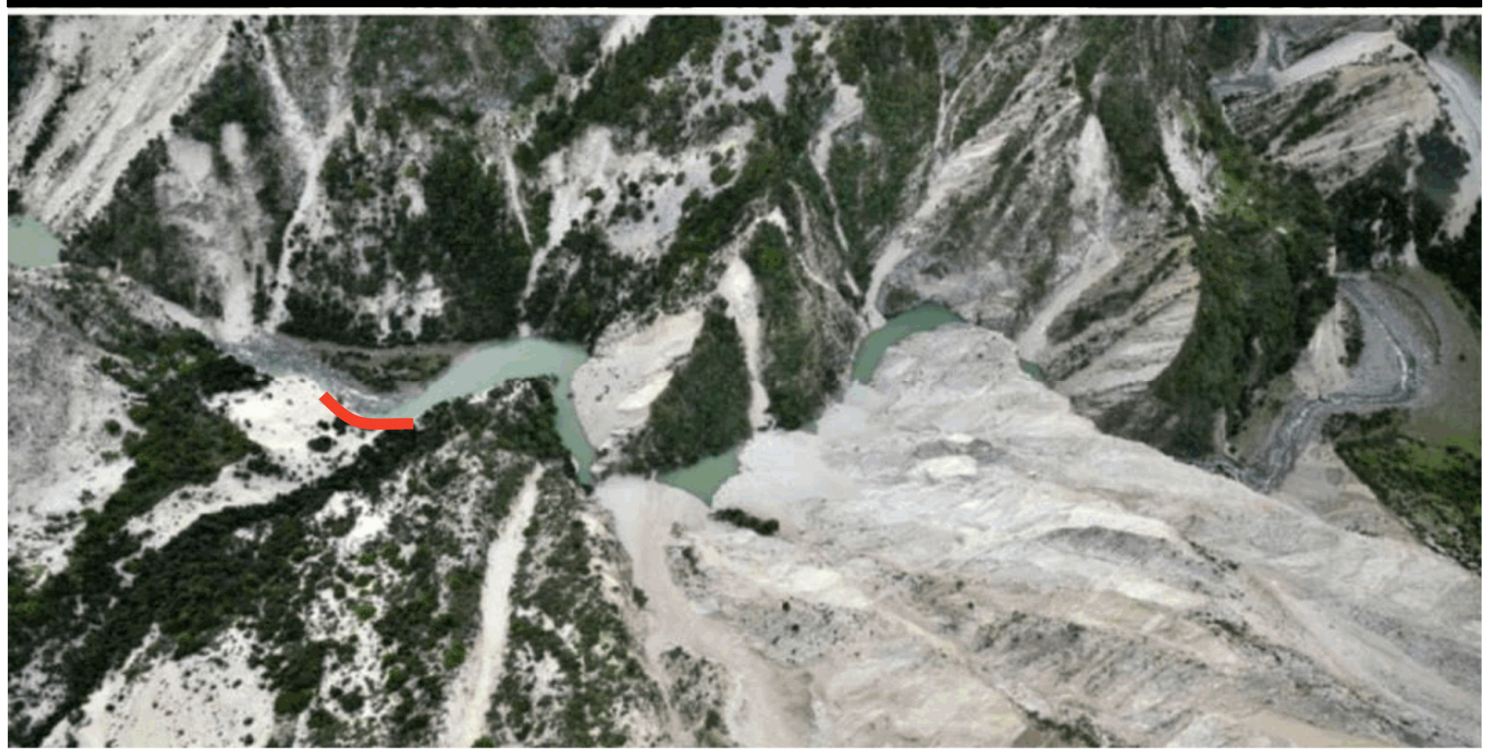

Figure 2.2: Ariel view of Mead Stream, Clarence Valley before $(A)$ and after $(B)$ the Kaikoura earthquake. Field area is (including all 3 sets of samples) is marked in red in both photographs. NZMG 25757405916050 - NZMG 25757395916019.

\subsection{Geological setting}

The present-day Kaikoura region in New Zealand is located close to the major boundary of the Pacific and Australian plates. The development of this plate boundary, including its timing and kinematics, remains uncertain. Recently it has been suggested that initial establishment occurred during the Late Cretaceous to early Paleocene (Strogen et al., 2017; Mortimer, 2018). The boundary on land is defined as the Alpine Fault and runs $600 \mathrm{~km}$ along 
the west coast of the South Island. Proximity to the fault has resulted in the regional deformation of the Kaikoura area (Van Dissen \& Yeats, 1991). Today, the modern-day Marlborough Fault System carries some of the displacement associated with the plate boundary. This fault system consists of five major faults within the region, the Awatere Fault, Clarence Fault, Hope Fault, Jordan Stream Thrust/Kekerengu Fault and London Hill Fault. Mead Stream is located in near to the Clarence fault (Figure 2.3).

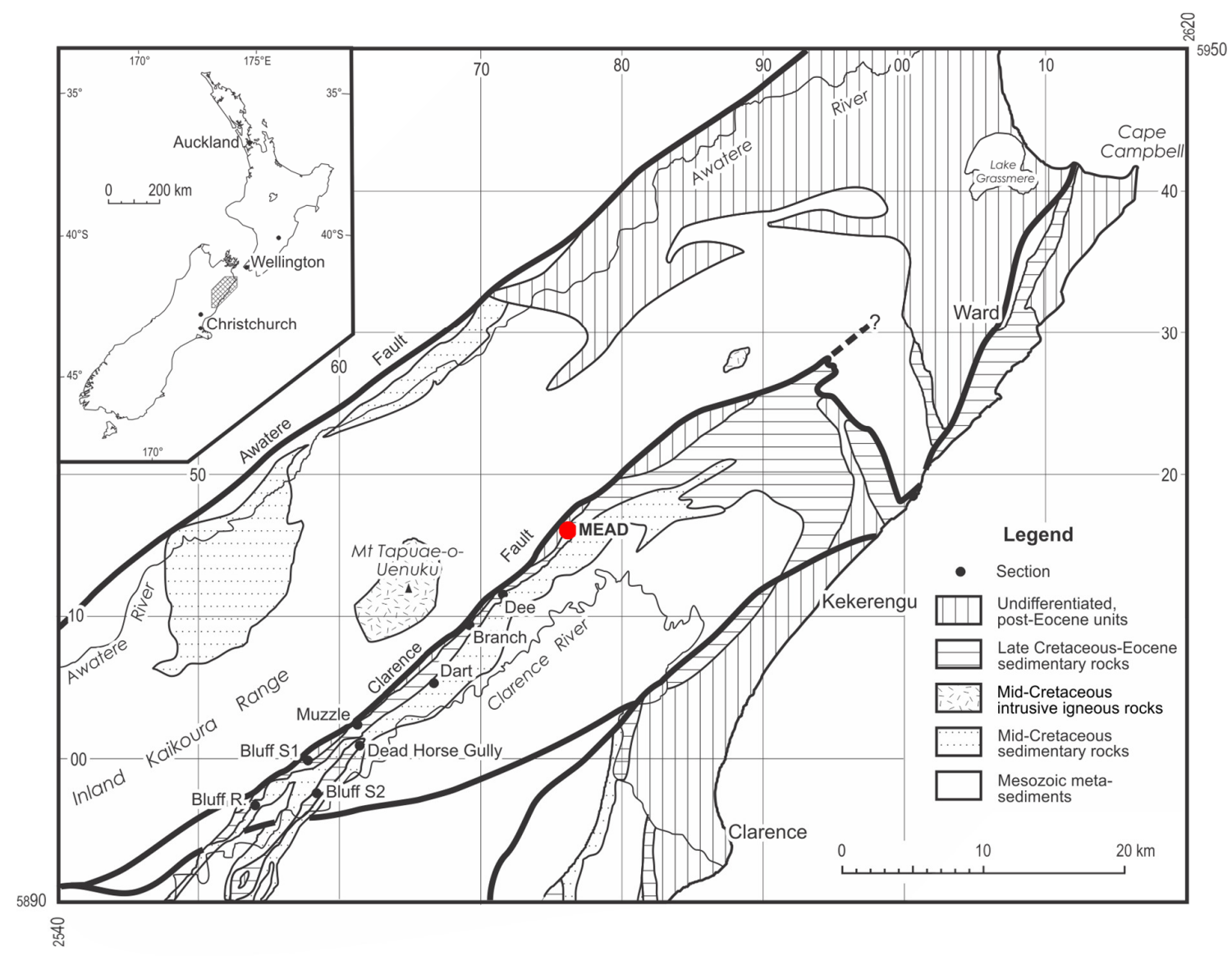

Figure 2.3: The Mead Stream section from upper Cretaceous to lower Eocene showing nearby faults (Crampton et al., 2003). Other nearby associated sections in the Clarence Valley are labelled. 


\section{Geological history}

As New Zealand separated from Gondwanaland in the Cretaceous, approximately $100 \mathrm{Ma}$ (King et al., 1999), southeastern Marlborough drifted north, by up to $25^{\circ}$ in latitude (Figure 2.4, Sutherland et al., 2001).

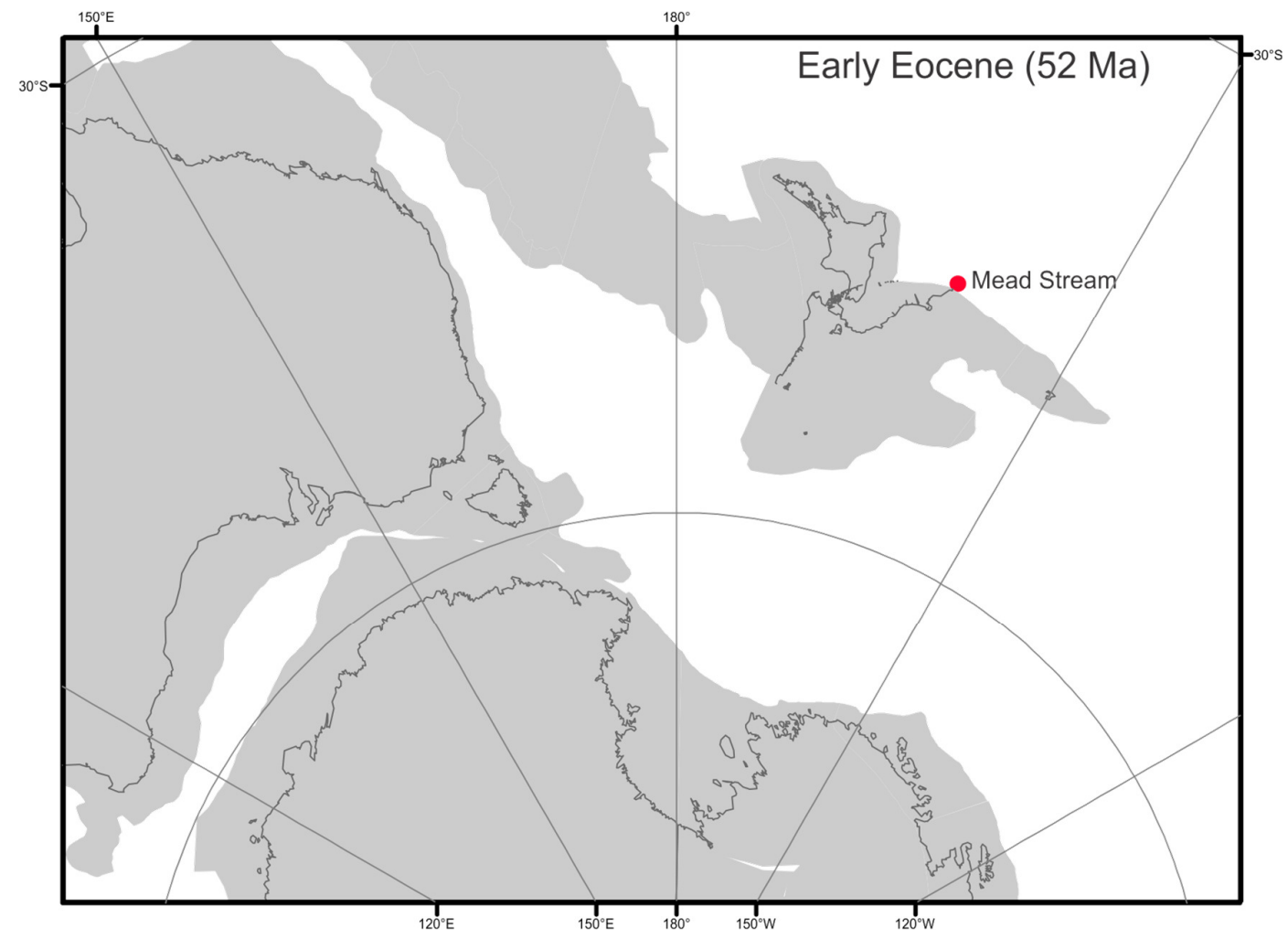

Figure 2.4: Position of the Mead Stream study area during the early Eocene, after northward drift. Paleogeographic reconstruction provided by Hannu Seebeck (2018) using GPlates software and the paleomagnetic reference frame of Matthews et al. (2016) and Torsvik et al. (2012).

During the Late Cretaceous and Paleogene, Mead Stream was positioned on the north facing edge of Zealandia at the interface between the East Coast Basin and Chatham Rise, (King et al., 1999; Sutherland et al., 2001; Crampton et al., 2003). The Marlborough region was subject to tectonic deformation, resulting in faulting and shortening during the Neogene. Deformation followed, consisting of a clockwise rotation of $100^{\circ}$ along the vertical axis and a shortening of faults, resulting in the continental shelf drowning at about $65 \mathrm{Ma}$ (Late 
Cretaceous/early Paleogene). The subsiding region was termed by King et al. (1999) the 'Marlborough paleo-embayment (MPE)' - an embayment on the shelf linking the Canterbury and East Coast basins (Figure 2.5 A, Crampton et al., 2003). This trough was filled with a mixture of pelagic and siliciclastic sediments. Pelagic sedimentation dominated on the eastern margin of the trough where a submarine platform formed the northwestern edge of the Chatham Rise. During the Cretaceous period, deposition of sediment occurred at outer shelf to bathyal depths as this paleo-platform gradually sank. Deposition was entirely at bathyal depths by the onset of the early Eocene (Crampton et al., 2003). Here on the paleo platform, siliciclastic sediment was negligible and pelagic sediment dominated in comparison with the East Coast and Canterbury basins (Figure 2.5B). It has been proposed that the reason for this is that terrigenous sediment from Chatham rise was insignificant and terrigenous input from the west was channelled into the MPE (Crampton et al., 2003)

During the Neogene, the development of the Pacific/Australian plate boundary resulted in significant changes to the regional geology and the uplift of the Muzzle Group was initiated (Field \& Uruski, 1997; Crampton et al., 2003). 


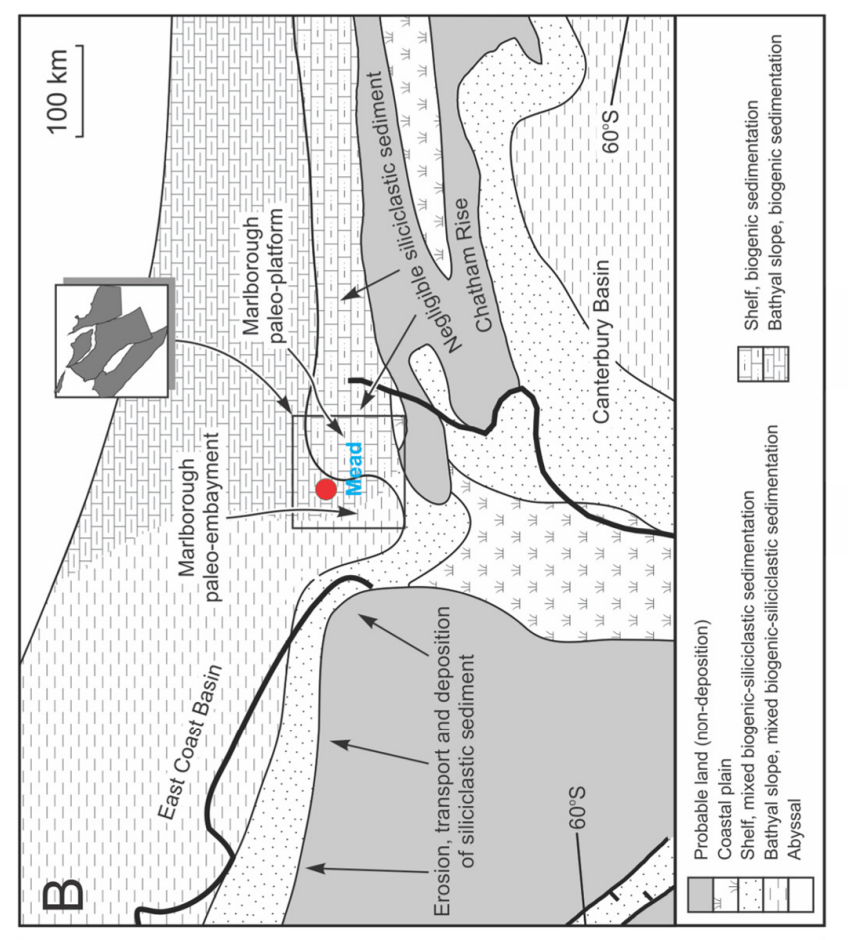

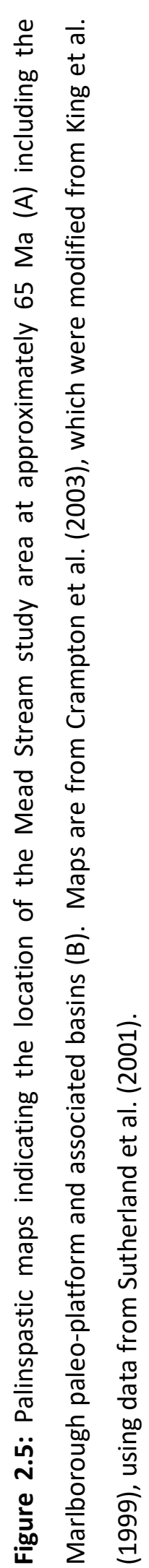




\subsection{Stratigraphy}

The basement geology of the Kaikoura region is dominated by the Torlesse composite terrane, which consists of a combination of sedimentary rocks primarily of Mesozoic age (Rattenbury et al., 2006). Overlying the Torlesse, From the Late Cretaceous to the Eocene and in stratigraphic order from oldest to youngest are the Seymour Group, Mead Hill Formation and Muzzle Group (which includes the Amuri Limestone).

These lithofacies in the eastern Marlborough region reflect the widespread deep-sea sedimentary succession identified in southwest Pacific offshore sediment cores: from terrigenous silt and clay, to siliceous ooze and calcareous ooze (Andrews et al., 1975). In the north-western sections of south-eastern Marlborough the equivalent units to the off-shore sediments are the Seymour Group (terrigenous), Mead Hill Formation (siliceous) and Amuri Limestone (calcareous) (Figure 2.6, Crampton et al., 2003). 

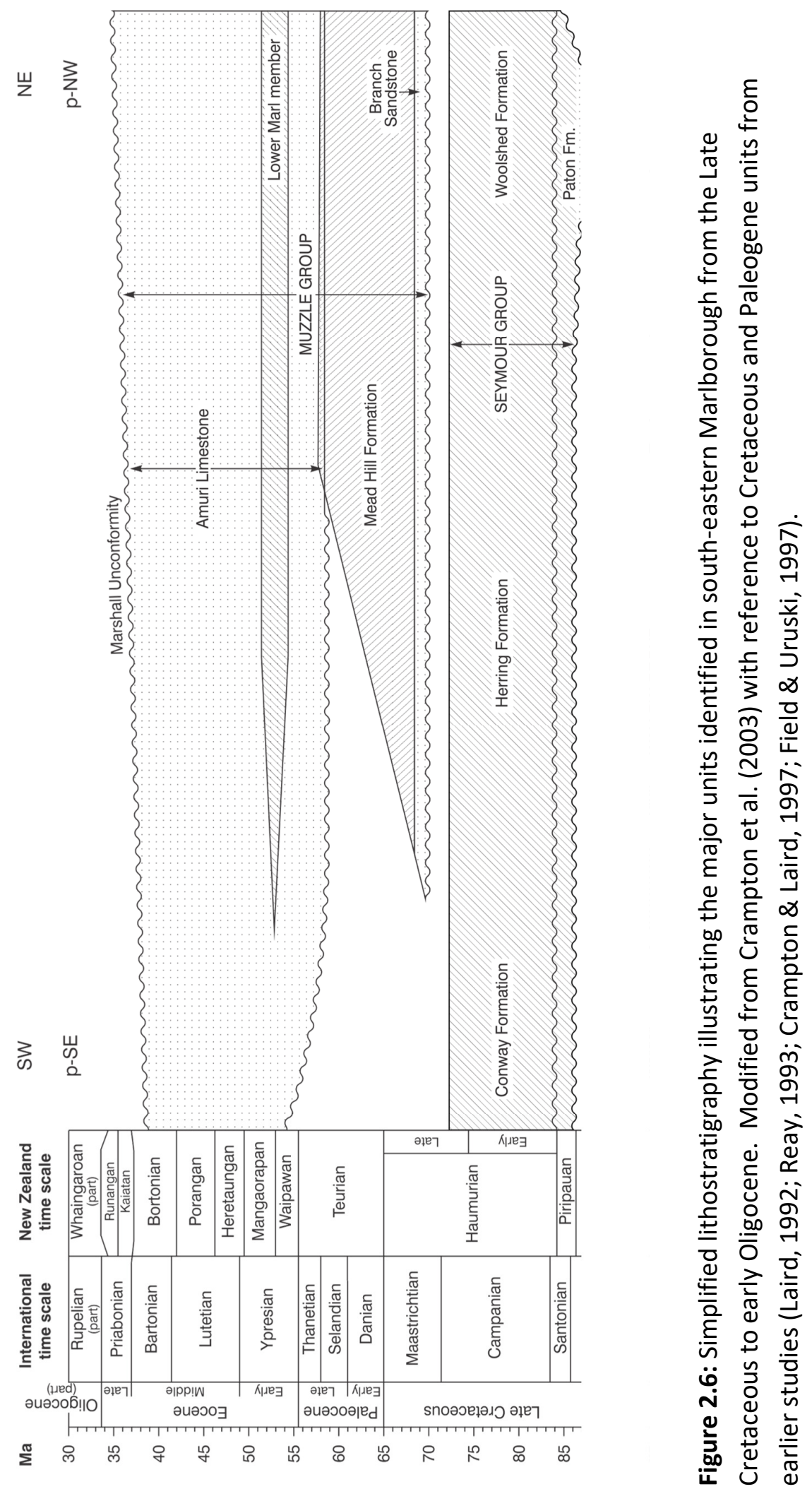


\subsubsection{Muzzle Group}

Muzzle Group forms a ridge stretching 35km along northwestern side of the Clarence River Valley (Strong et al., 1995). Minor faulting is observed in the surrounding hillside outcrops with offsets no greater than $50 \mathrm{~m}$. Muzzle Group has been cut perpendicular to strike by a series of streams in the northeast Clarence River valley including Mead Stream (Reay, 1993).

Following Hollis et al. (2005a), this group is divided into three formations: Mead Hill Formation, Waipawa Formation and Amuri Limestone, although Waipawa Formation has only been observed at Mead Stream (Figure 2.7). Mead Hill Formation and Amuri Limestone are present in all sections south of Mead Stream, including Dee Stream, Branch Stream, Dart Stream, Muzzle Stream, Bluff Stream and Limestone Hill (Reay, 1993). Further to the southwest Mead Hill Formation is truncated by the basal member of the Amuri Limestone, Teredo Limestone. 


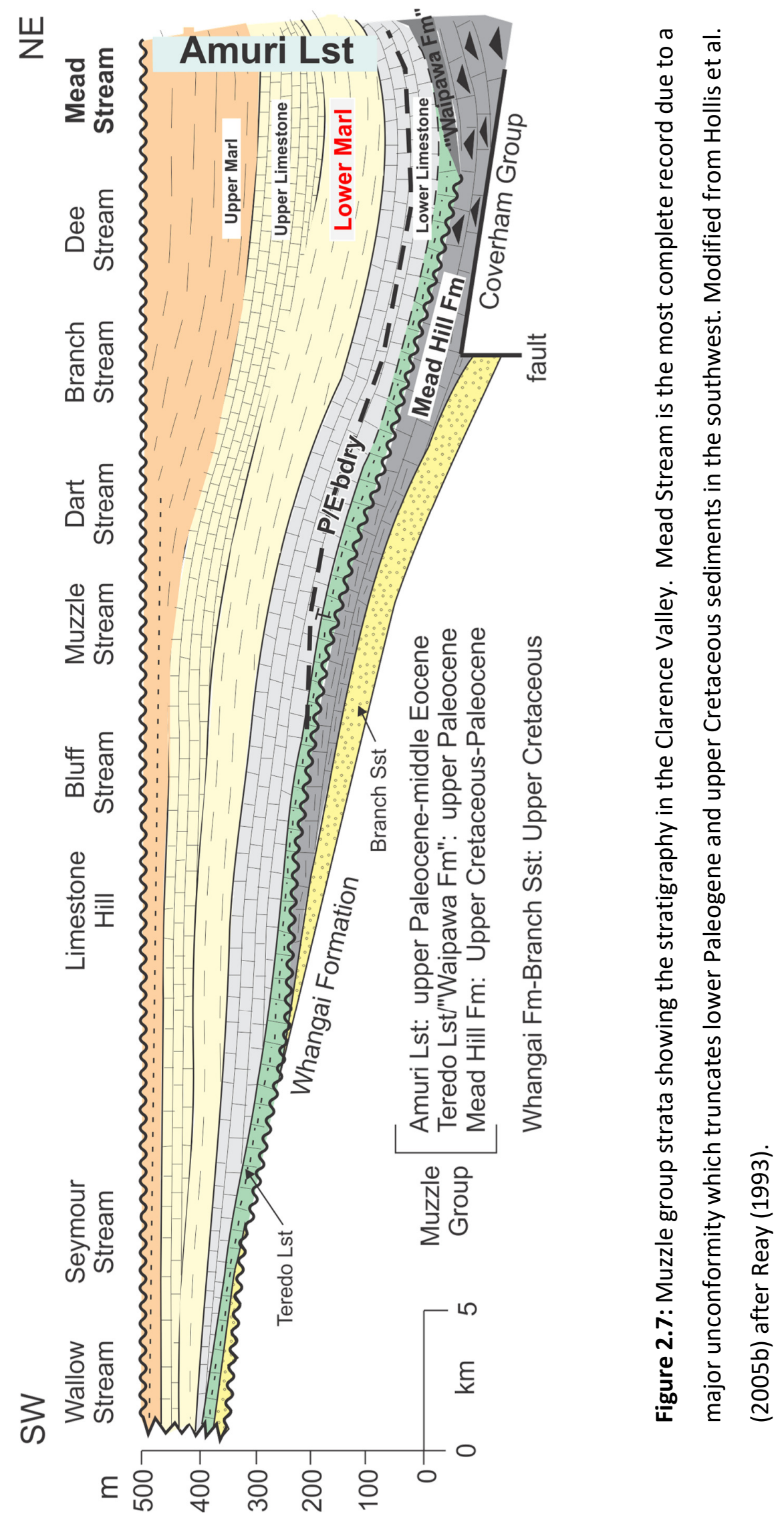




\section{Mead Hill Formation}

Mead Hill Formation is the lowest stratigraphic unit of the Muzzle Group, consisting of chert-rich micritic limestone (Field \& Uruski, 1997). Deposition of this formation began in the Late Cretaceous and continued through to the middle Paleocene. It is deposited on a broad platform with a low gradient (Figure 2.7) which increases towards the south and narrows towards the southwest (Crampton et al., 2003). To the southwest the Mead Hill Formation thins and becomes absent, likely due to an unconformity (Strong \& Beggs, 1990). Within the Mead Hill Formation at Mead Stream, the Cretaceous/Paleogene (K/Pg) boundary is expressed as an abrupt change from limestone to chert and is located c. $170 \mathrm{~m}$ above the base of the formation. The boundary is overlain by $160 \mathrm{~m}$ of Paleocene strata (Strong et al., 1995; Hollis et al., 2003a). Hollis et al., (2003a) suggested that the boundary is a disconformity due to biostratigraphic evidence and the absence of a boundary clay. All measurements of the Mead Stream section in this study refer to height in metres above this $\mathrm{K} / \mathrm{Pg}$ boundary.

\section{Waipawa Formation}

Waipawa Formation is an organic rich dark brown to black, non-calcareous mudstone and was first identified at Mead Stream in 2005 (Hollis et al., 2005b). Immediately overlying the Mead Hill Formation, it is described as two organic-rich siliceous mudstone layers (A and B) separated by an interval with little organic content. The lower mudstone, labelled $A$ is the equivalent of the 'Black Siltstone' unit referred to by Reay (1993). To date, the Waipawa Formation has not been found in sections containing the Muzzle Group other than in Mead Stream (Figure 2.7). The Teredo Limestone is considered to be laterally equivalent to the Waipawa Formation in the stratigraphic sections to the south, where the Amuri Limestone shallows. In these sections the Teredo Limestone is recognised as the basal member of the Amuri Limestone.

Waipawa Formation is a useful stratigraphic unit marker in Paleogene sections throughout the East Coast Basin in New Zealand (Moore, 1988, 1989b, 1989a). Deposition of the Waipawa Formation likely occurred under cool, dysoxic conditions coupled with a decrease in global sea level (Hollis et al., 2014b). The typical Waipawa lithology lithotype is characterised by relatively high TOC (Total Organic Carbon) and ${ }^{13} \mathrm{C}$ enrichment. Interestingly, 
the Mead Stream interval, whilst belonging to this lithotype, differs from other locations as it is well-bedded, includes a $3 \mathrm{~m}$-thick limestone unit and contains abundant radiolarians as well as rare foraminifera (Hollis et al., 2005a).

\section{Amuri Limestone}

Amuri Limestone was first identified and referenced in the late nineteenth century (Buchanan, 1868; Hector, 1868; Haast, 1871; Hutton, 1877). The Amuri Limestone beds are comprised of siliceous limestone, marly limestone and marl. At Mead Stream, the Amuri Limestone overlays the Waipawa Formation and lies 115-523 m above the K/Pg boundary, and corresponds to the middle Paleocene to middle Eocene (Strong et al., 1995).

Based on lithology, Reay (1993) divided the Amuri Limestone into four informal units plus the Teredo Limestone Member. The four units are: Lower Limestone, Lower Marl, Upper Limestone and Upper Marl. A fifth lithostratigraphic unit - Black Siltstone - is present in the absence of Teredo Limestone, and later re-defined as the aforementioned Waipawa Formation by Hollis et al (2005a).

\section{Mead Stream}

The primary units in the Mead Stream section are the Mead Hill and Amuri Limestone formations, which consist of micritic limestone, chert and marl (Strong et al., 1995; Hollis et al., 2005b). The Mead Stream section is the type section for the Mead Hill Formation (Webb, 1966; Webb, 1971). Morris (1987) completed the first detailed measured section for Mead Stream in which the entire section was included in the Amuri Limestone Group, with the lower part assigned to the Mead Hill Formation. Further study by Reay (1993) established the Muzzle Group and defined its formations. This lithostratigraphic nomenclature was followed by Strong et al. (1995) and by Hollis et al. (2005b) and is used in this study. The units of the Mead Stream Section are described below:

\section{Lower Limestone (115-205 m)}

The Lower Limestone is light to medium grey indurated limestone containing yellow, brown and blackish chert nodules (Reay, 1993; Strong et al., 1995). Lower Limestone is late Teurian to Late Waipawan in age (Strong et al., 1995; Dallanave et al., 2015). 
Lower Marl (205-320 m)

Lower Marl is dated as Waipawan to Heretaungan (early to middle Eocene; Strong et al., 1995; Raine et al., 2015) and is the focus of this study. The base of the Lower Marl lies $204 \mathrm{~m}$ above the $\mathrm{K} / \mathrm{Pg}$ boundary (Hollis et al., 2005b) and is $116 \mathrm{~m}$ thick (Dallanave et al., 2015). Within the Lower Marl, beds of soft greenish-grey marl and harder light tan limestone alternate (Figure 2.8). The beds of marl are more prevalent in comparison to the Lower Limestone and make up approximately 50\% of the lithology (Slotnick et al., 2012). The Waipawan-Mangaorapan (Dw-Dm) boundary, located between 260.9-263 m, lies just below an interval of deformed strata at 265-279 $\mathrm{m}$ in the Lower Marl.

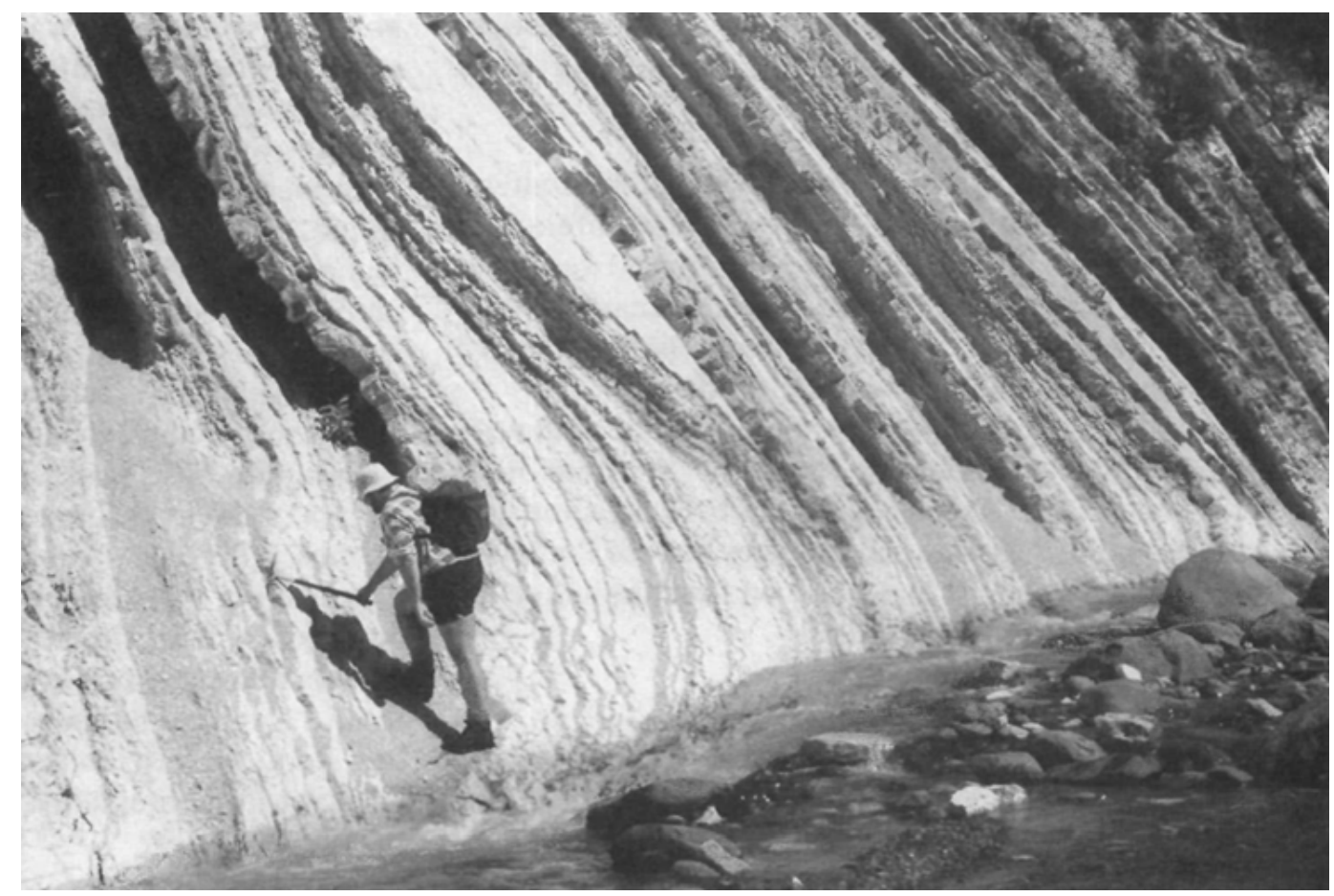

Figure 2.8: Alternating marl and limestone beds within the Lower Marl at Mead Stream (Strong et al., 1995).

Upper Limestone (320-397 m)

The Upper Limestone spans 77 m (Dallanave et al., 2015) and consists of highly indurated limestone beds that are approximately $10 \mathrm{~cm}$ thick (Reay, 1993; Strong et al., 1995). Upper 
Limestone aligns with the middle Eocene (Heretaungan to early Bortonian) stages (Strong et al., 1995; Dallanave et al., 2015).

\section{Upper Marl (397-523 m)}

Upper Marl is $126 \mathrm{~m}$ thick and has been assigned to the middle Eocene (Bortonian) stage. It is made up of grey-green soft marls alternating with moderately indurated limestone beds (Morris, 1987; Strong et al., 1995; Dallanave et al., 2015). The contrast between the limestones and marls is less pronounced than in the Lower Marl (Strong et al., 1995). The top of the Amuri Limestone (at $523 \mathrm{~m}$ ) is an unconformity with the overlying Weka Pass Stone Formation, which is Waitakian in age (late Oligocene-early Miocene) (Reay, 1993; Strong et al., 1995; Hollis et al., 2005b). This unconformity represents a hiatus of several million years, spanning late middle Eocene to late middle Oligocene. 


\section{CHAPTER 3: BACKGROUND AND PREVIOUS STUDIES}

\subsection{Global climate of the past}

The Earth's climate over the past 540 million years has fluctuated between a warm 'greenhouse state' and an 'icehouse state' according to the presence or absence of glaciation at the poles (Crowell \& Frakes, 1970). Geochemical studies indicate that global climate in the early Paleogene, a focus of this study, was a greenhouse world (Zachos et al., 2001; Zachos et al., 2008). Prior to this warm state, at the end of the Cretaceous period and into the early Paleocene, Sea Surface Temperatures (SSTs) were stable and relatively cool at around $8-11^{\circ} \mathrm{C}$ as recorded by oxygen isotopes in benthic foraminifera, assuming an ice free world (Figure 3.1: Zachos et al., 2008). The ratio of ${ }^{18} \mathrm{O} /{ }^{16} \mathrm{O}$ isotopes $\left(\delta^{18} \mathrm{O}\right)$ from benthic foraminifera provides a record of ancient water temperature. This is because ${ }^{16} \mathrm{O}$ is lighter and is preferentially fractionated into the air in warmer regions, leaving behind an ocean rich in ${ }^{18} \mathrm{O}$. The lighter ${ }^{16} \mathrm{O}$ is captured into the ice sheets during glacial periods, therefore the ratio is dependent on ice volume at the poles and temperature at which precipitation occurs. In a greenhouse world (e.g. the early Paleogene) where ice sheets are absent or minimal $\delta^{18} \mathrm{O}$ values from benthic (bottom dwelling) foraminifera are inferred to be analogous to high latitude Sea Surface Temperatures (SST) (Figure 3.1) although this may indicate a winter bias SST (Hollis et al. 2012; Cramwinckel et al., 2018).

This was followed by a gradual warming beginning at 58 million years ago (Ma), with temperatures peaking at $51-52 \mathrm{Ma}$ at approximately $15^{\circ} \mathrm{C}$ and more pronounced warming occurring in polar regions during the early Eocene (e.g. Sluijs et al., 2006). This peak in warming is termed the Early Eocene Climatic Optimum (EECO) and is thought to reflect a period with the highest prolonged temperatures in the Cenozoic (Figure 3.1; Zachos et al., 2001)

Succeeding the EECO in the early Eocene, a gradual cooling phase ensued until the EoceneOligocene transition. This is illustrated by the large drop in temperature inferred by the deep-sea benthic foraminifera oxygen isotope curve (Figure 3.1). 
It is thought that the dramatic cooling (Figure 2.1) at the end of the Eocene enabled the ice sheets to become fully established by the onset of the Oligocene in Antarctica (Shackleton \& Kennett, 1975; Zachos et al., 2001; Barrett, 2003; Zachos et al., 2008), although a recent study suggests their short-lived presence in the late Paleocene due to the presence of richorganic Waipawa formation (Hollis et al., 2014b). The 'ice-house' state established at the Eocene/Oligocene boundary continued through the Miocene, Pliocene and Quaternary period into the present day. 
This content is unavailable.

Please consult the print version for access.

Figure 3.1 Deep-sea benthic foraminifera oxygen isotope curve including estimated SSTs for the Cenozoic and including corresponding atmospheric $\mathrm{CO}_{2}$ levels. Significant climatic events are labelled on the curve including the EECO. Figure from Zachos et al. (2008) modified by Escutia et al. (2011). 


\subsubsection{The Early Eocene Climatic Optimum}

Kirtland-Turner et al. (2014) defined the EECO as occurring from 53-50 Ma, although studies of the southwest Pacific have shown that it may have continued until $49 \mathrm{Ma}$ (Creech et al., 2010; Hollis et al., 2012). The EECO was a time characterised by little or no polar ice (Zachos et al., 2001; Zachos et al., 2008). The $\delta^{18} \mathrm{O}$ values from deep-sea benthic foraminifera oxygen isotope data in Figure 3.1 illustrate that the of EECO appears to occur globally at approximately 53 to $51 \mathrm{Ma}$. Corresponding with the warmer temperatures of the EECO is a substantial increase in global $\mathrm{CO}_{2}$ levels (Figure 3.1) (Lowenstein \& Demicco, 2006; Zachos et al., 2008). Additionally, a $1.5 \%$ long term reduction in $\delta^{18} \mathrm{O}$ values indicates warmer ocean temperatures spanning the EECO (Zachos et al., 2001). As stated earlier, the exact termination of the EECO remains unclear. Although it appears to end around 50-49 Ma, planktonic foraminifer oxygen isotope records and TEX 86 records in deep-sea cores indicate this may have been dependent on local conditions (Pearson et al., 2007; Hollis et al., 2009). $\mathrm{TEX}_{86}$ analysis determines ancient temperature based upon ratios of membrane lipid structures within marine Archaea, which are sensitive to heat (Schouten et al., 2002).

In the SW Pacific, the transition from the EECO into the icehouse state, and hence the termination, is thought to occur at approximately $48.7 \mathrm{Ma}$ (Creech et al., 2010). The Lower Marl at Mead stream is of particular interest as it represents an expanded EECO interval relative to the intervals observed in open ocean settings (Slotnick et al., 2012).

\subsubsection{Hyperthermals during the early Eocene}

Superimposed on the rising warming trend in the late Paleocene to early Eocene are a series of peaks in temperature, lasting less than 200 kyr. They are referred to as 'hyperthermals' and correspond to negative Carbon Isotope Excursions (CIEs) coupled with evidence for warming (Zachos et al., 2001; Cramer et al., 2003; Lourens et al., 2005). A CIE equates to a decrease $\delta^{13} \mathrm{C}$ which reflects abundance of the lighter ${ }^{12} \mathrm{C}$ relative to ${ }^{13} \mathrm{C}$ and is attributed to a perturbation in the exogenic carbon cycle. The multiple hyperthermals in the Eocene have been associated with changes in the atmosphere, hydrosphere, geosphere and biosphere (Bowen et al., 2006). These events provide an insight into the global carbon cycle, climate 
and ecosystems during a period of warming and increased input of isotopically light carbon into the oceans (Bowen et al., 2006; Mclnerney \& Wing, 2011).

\section{The Paleocene-Eocene Thermal Maximum (PETM)}

The Paleocene-Eocene Thermal Maximum (PETM or Eocene Thermal Maximum 1, ETM-1) occurred at approximately $56 \mathrm{Ma}$ and is the most pronounced and well-studied of the hyperthermals. This short-lived episode of pronounced global warming spans approximately $220 \mathrm{kyr}$ and occurred at the Paleocene-Eocene boundary. It is defined by rapid negative $\delta^{13} \mathrm{C}$ and $\delta^{18} \mathrm{O}$ excursions reflecting an immense release of ${ }^{13} \mathrm{C}$ depleted carbon into the oceans and atmosphere (Kennett \& Stott, 1991; Bowen et al., 2006; Sluijs et al., 2007; McInerney \& Wing, 2011).

Because the uptake of magnesium as a trace element is primarily temperature dependent, Magnesium/Calcium (Mg/Ca) ratios are also used as a paleothermometer. Laboratory experiments of cultured planktic foraminifera have shown that as temperature increases, $\mathrm{Mg} / \mathrm{Ca}$ ratios increase proportionally (Nürnberg et al., 1996). Data from various proxies include TEX ${ }_{86}$ analysis and both $\delta^{18} \mathrm{O}$ values and $\mathrm{Mg} / \mathrm{Ca}$ ratios from planktic foraminifera suggest that the PETM reflected global warming of around $4-8{ }^{\circ} \mathrm{C}$ (Sluijs et al., 2006; Sluijs et al., 2007; McInerney \& Wing, 2011; Jones et al., 2013; Hollis et al., 2015).

With increasing depth, the rate of calcium carbonate dissolution increases. The Carbon Compensation Depth (CCD) is the depth at which the rate of calcium carbonate accumulation equals that of carbonate dissolution. Consequently, carbonate is readily dissolved below the CCD. At the time of the PETM, the rapid release of carbon caused the CCD to rise sharply, indicating significant absorption of excess $\mathrm{CO}_{2}$ (Zachos et al., 2005). It is believed that at the PETM the rapid release of carbon was absorbed into the atmosphere causing global warming and partially absorbed into the ocean, causing ocean acidification (Zachos et al., 2005).

Other events associated with the PETM include extinction of deep-sea benthic foraminifera (Kennett \& Stott, 1991; Thomas \& Shackleton, 1996) and the presence of sub-tropical SSTs 
in the Arctic (Sluijs et al., 2006). Koch et al. (1992) correlated the carbon isotope record from the PETM with terrestrial extinctions of mammals in the Cenozoic.

The PETM is expressed in both deep-sea records and in continental margin deposits (e.g. Crouch et al., 2001; Schmitz \& Pujalte, 2003; Hollis et al., 2005a; Hollis et al., 2005b; Bowen \& Beitler Bowen, 2008). The observed increase in terrigenous input at the marginal (shelf) environments during the PETM is a likely response to increased precipitation due to higher temperatures (Crouch et al., 2003; Bowen et al., 2004; Nicolo et al., 2007).

\section{Other early Eocene CIEs}

Cramer et al. (2003) identified additional negative CIEs of at least $0.5 \%$ that he labelled 'A to $L^{\prime}$, in several open ocean records from the early Paleogene. These events are lower in magnitude and shorter in duration than the PETM and include (in order of decreasing age) the ETM-2/H-1, H-2, I-1 and I-2 hyperthermals. Also identified by Cramer (2003), the J, K and $L$ events are expressed in the EECO. This study includes high resolution sampling through the J event.

\section{Causes of PETM and other CIEs}

It is likely that the PETM and other associated CIEs following the PETM are a response to a massive release of ${ }^{13} \mathrm{C}$ depleted carbon (Lourens et al., 2005; Nicolo et al., 2007). The source of the increase in carbon during the PETM is yet to be established and is a topic of debate. A disassociation of submarine gas hydrates has been suggested as the primary source which in turn would cause an increase in atmospheric greenhouse gases and lead to or intensify warming (Dickens et al., 1995; Dickens et al., 1997; Lourens et al., 2005; Dickens, 2011). Alternatively Deconto et al. (2012) proposed that permafrost in polar regions may have melted abruptly and release stored methane at the end of the Paleocene. An alternative hypothesis (Kurtz et al., 2003) suggests that widespread peat and coal burning from wildfires may have been responsible for the large injection of organically light carbon. Further studies (Svensen et al., 2004; Svensen et al., 2010) propose volcanic activity on the North Atlantic seafloor as a release mechanism for substantial amounts of methane.

There is evidence to suggest that the PETM and hyperthermal events were modulated by astronomically paced cycles (Lourens et al., 2005). The Milankovitch cycles of obliquity ( 41 
kyr cycle), precession ( $21 \mathrm{kyr}$ ) and eccentricity ( 100 and $\sim 400$ kyr cycles) are related to tilt, wobble and orbital path of the earth around the sun, respectively. This forcing constantly changes the earth's position in relation to the sun and therefore affects the insolation of the planet over cycles of thousands of years. If the widespread permafrost melting theory is correct, this may have been triggered when eccentricity and obliquity components reached their maximum (DeConto et al., 2012).

\subsubsection{Early Eocene temperature reconstruction in the SW Pacific}

Paleoenvironmental research of these warming events during the early Paleogene has relied heavily on data from open ocean cores. Whilst these deep-sea records are valuable, the most expanded marine records are found on marginal marine (shelf) settings where carbon dissolution is minimal. Studies of the southwest Pacific early Paleogene climate were historically limited because the area consists primarily of ocean and deep-sea drilling is expensive and logistically challenging. However, over the last few decades numerous expeditions Ocean Drilling Program, Deep Sea Drilling Program and International Ocean Discovery Program, (ODP, DSDP and IODP) expeditions and studies of several onshore sections in Aotearoa/New Zealand have contributed to a growing picture of global early Paleogene climate.

Deep Sea Drilling Project (DSDP), Leg 29 provided the first record of temperatures during the Paleogene in the Southern Ocean (Shackleton \& Kennett, 1975). Shackleton and Kennett (1975) surveyed the stable isotopes of foraminifera from cores at three of the ten deep sea sites drilled on this expedition. Estimated SST from Site 277 was about $19^{\circ} \mathrm{C}$ in the early Eocene, $13^{\circ} \mathrm{C}$ in the middle Eocene, $11^{\circ} \mathrm{C}$ in the late Eocene, and $7^{\circ} \mathrm{C}$ in the Oligocene. Due to the effect of diagenetic overprint on planktic foraminifera used for estimation of SSTs it is thought that these temperatures have been underestimated (Sexton et al., 2006; Pearson et al., 2007). More up to date studies based on $\mathrm{Mg} / \mathrm{Ca}$ ratios and TEX ${ }_{86}$ values present estimated SSTs of approximately $10^{\circ} \mathrm{C}$ warmer than those previously published in 1975 (Liu et al., 2009; Hollis et al., 2015; Hines et al., 2017).

In these recent studies, different proxies have been collated to provide an overall estimate of both marine and terrestrial climate during the early Paleogene in the Aotearoa/New 
Zealand region (Figure 3.2). Presented on the left of the figure, $\mathrm{Mg} / \mathrm{Ca}$ ratios, $\delta^{18} \mathrm{O}$ ratios from benthic foraminifera and TEX ${ }_{86}$ data from several studies (Shackleton \& Kennett, 1975; Zachos et al., 2001; Bijl et al., 2009; Hollis et al., 2009; Hollis et al., 2012) combine to give a robust estimation of SST. Reconstructions in the SW Pacific indicate that these SSTs may have been between $26-28^{\circ}$ (Hollis et al., 2012). Multiproxy estimates for ocean temperatures include the Hampden Beach and mid-Waipara River sections in the South Island of New Zealand. The sea floor temperatures range from $10-20^{\circ} \mathrm{C}$ in the Eocene coupled with estimates of $22-33^{\circ} \mathrm{C}$ for SSTs (Figure 3.2).

In the right hand graph in this figure is a summary of studies by Mildenhall (1980) Hornibrook (1992), Kennedy (2003) and Hollis et al. (Hollis et al., 2009). Data from fossil plants, molluscs, foraminifera and dinocysts provide an estimate of mean annual temperature. This (primarily terrestrial) fossil record from the early Eocene in the southwest Pacific spanning 40 to $60 \mathrm{Ma}$, contains both tropical and sub-tropical species and temperatures range from $12^{\circ}-25^{\circ} \mathrm{C}$ throughout the Eocene. 


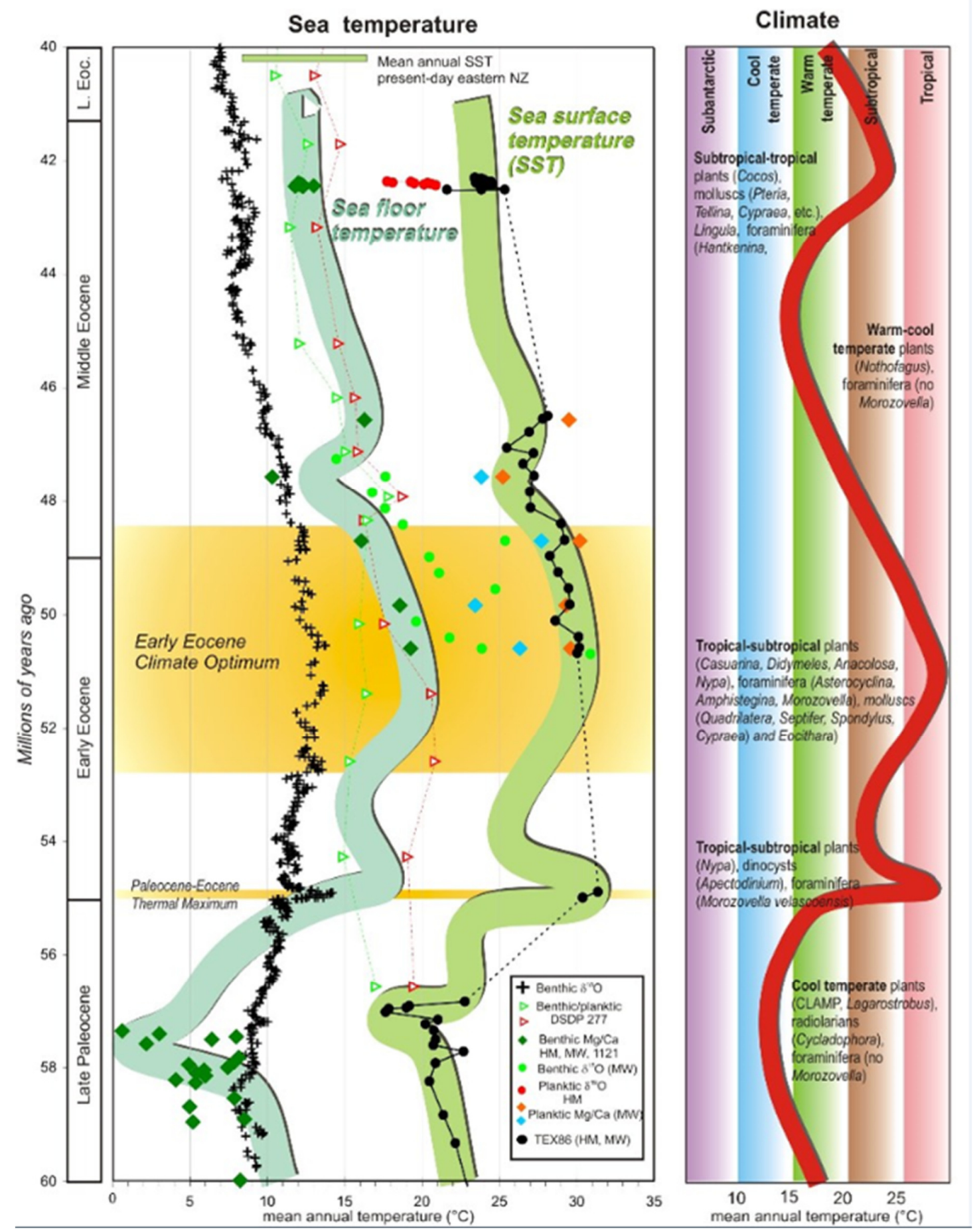

Figure 3.2: Estimated sea temperature and climate for the NZ region 60-40 Ma. Climate estimation from the fossil record is on the right. Supplied by C. Hollis; after Hollis et al. (2012). 
As discussed, temperatures obtained from $\mathrm{TEX}_{86}$ and $\mathrm{Mg} / \mathrm{Ca}$ have indicated temperatures of close to $30^{\circ} \mathrm{C}$. Moreover, SSTs from these geochemical proxies suggest a virtually nonexistent latitudinal gradient in the early Eocene (Bijl et al., 2009). Replication of these conditions via climate models (e.g. Huber \& Caballero, 2011) has proven difficult (Hollis et al., 2009). It seems that all Paleogene SW Pacific proxies suffer from a warm bias (Hollis et al., 2012). These elevated temperatures could reflect seasonality or oceanic currents (Hollis et al., 2012; Hollis et al., 2014a). A recent calibration of TEX ${ }_{86}$ indicated lower temperatures through the Eocene and proposed there may be overestimates in temperature in the vicinity of $5-9^{\circ} \mathrm{C}$ in the SW Pacific (Hollis et al., 2012; Hollis et al., 2014a).

Moreover, recent estimated temperatures from microfossil analyses in the SW Pacific are in contrast with the tropical and sub-tropical temperatures indicated by the majority of studies using geochemical proxies $\mathrm{TEX}_{\mathbf{8 6}}$ and $\mathrm{Mg} / \mathrm{Ca}$. Nannofossil taxa from four SW Pacific sites imply temperate and polar temperatures from early-mid Eocene with a peak of warm-water taxa coinciding with the EECO (Dallanave et al., 2016; Shepherd \& Kulhanek, 2016; Shepherd, 2017). Furthermore, analysis of radiolarian assemblages suggest that tropical temperatures were not reached at all during the Eocene and that warm subtropical water masses may have extended to approximately $55^{\circ}$ South only during the EECO (Pascher, 2017). The warmer assemblages in these studies could be explained by the southward expansion of the warm proto-East Australian Current (EAC) (Hollis et al., 2012; Hines et al., 2017) from 53-49 Mya.

\subsection{Paleontology}

This section describes the microfossils examined in this thesis and their applications followed by a review of previous paleontological findings at Mead Stream and the associated sections in the Clarence Valley.

\subsubsection{Foraminifera}

The order Foraminiferida (informally foraminifera) belongs to the kingdom Protista, subkingdom Protozoa, phylum Sarcomastigophora, subphylum class Granuloreticulosea. These microfossils are typically between $100 \mu \mathrm{m}-1 \mathrm{~mm}$ in length or diameter, but some 
species can be up to several centimetres long (Cushman, 1948). Most species possess a shell or 'test' which is made up of calcium carbonate, or agglutinated grains of silt or fine sand cemented together. There are two ecological categories of foraminifera - benthic (bottom dwelling) and planktic (water-column dwelling). On death tests either fall to (planktic) or remain at (benthic) the bottom of the ocean and are incorporated into marine sediments. Tests are distinct between species, abundant and can be well-preserved. Foraminifera provide valuable tools for paleoclimate analysis as they have restricted ecological distributions (Jones, 2013). There are three classifications of foraminifera wall texture used in taxonomy - microperforate, spinose and non-spinose. This study we will focus on specimens from the latter two. Spinose refers to a wall texture consisting of short spines and is common in planktic forms (e.g. Subbotina). Non-spinose foraminifera are divided into smooth and muricate types of wall. Muricate foraminifera are characterised by wall surface featuring pointed/conical pustules (e.g. planktic genera Acarinina and Morozovella genera). For examples of these wall textures see Figure 3.3.

\section{This content is unavailable.}

Please consult the print version for access.

Figure 3.3: Spinose wall texture of foraminifera results in a honeycomb appearance e.g. Subbotina (Globigerina) triloculinoides $(\mathrm{A})$ whilst muricate species features protruding pustules e.g. Morozovella (Globorotalia) crater (B). Sketches are by R.C Brazier from Hornibrook et al., (1989).

\section{Foraminifera applications to biostratigraphy and paleoecology}

Several factors affect the ecological distribution of foraminifera including ocean currents, temperature, water depth, salinity and sedimentary environment. Light availability, turbulence, $\mathrm{pH}$ and calcium carbonate availability are additional factors (Jones, 2013). 
Foraminifera are abundant in past and present oceans, and distinct species or genera have constrained habitat preferences and tolerances. Therefore, analysis of foraminifera assemblages can provide insight into the paleodepth, paleolatitude and water mass of their habitat (Strong et al., 1995; Jones, 2013).

Analysis of foraminiferal tests is useful because their shell records the chemical composition of the sea water around them. Specific planktic genera and species reflect specific oceanic conditions. When Douglas and Savin (1978) examined $\delta^{18} \mathrm{O}$ values of Paleocene foraminifera, Subbotina were found to a have more positive $\delta^{18} \mathrm{O}$ than Morozovella and Acarinina and a more negative $\delta^{18} \mathrm{O}$ than benthic foraminifera. This evidence suggests that Subbotina likely existed in the thermocline/deeper water-dwelling zone below the warmer surface/mixed-layer morozovellids and acarininids. Additionally, geochemical analysis of the tests of foraminifera can provide $\delta^{13} \mathrm{C}$ and magnesium/calcium $(\mathrm{Mg} / \mathrm{Ca})$ ratios which record carbon cycle dynamics and oceanic temperature, respectively.

Planktic foraminifera are abundant in deep oceanic waters whereas benthic foraminifera dominate the shelf. This resulting planktic/benthic (P/B) ratio, (or in this thesis percentage of planktic foraminifera), is a useful tool to approximate distance from shore with the percentage of planktics increasing as distance from the shoreline and water depth increases. However planktic percentages are also dependent on depth and organic flux (Van der Zwaan et al., 1990). Because benthic organisms rely on primarily on organic matter raining through the water column as a source of food, the proportion of benthics has been used as a productivity indicator (Berger \& Diester-Haass, 1988). Furthermore, some benthic foraminifera species can be used as depth indicators according to their bathymetric ranges (Tjalsma \& G.P., 1983; Van Morkhoven et al., 1986).

\section{Foraminifera in the early Paleogene}

The mass-extinction at the $\mathrm{K} / \mathrm{Pg}$ Boundary, resulted in the extinction of almost all planktic foraminifer species (e.g. Hornibrook et al., 1989; Schulte et al., 2010). Although they underwent some faunal turnover (Coccioni \& Marsili, 2007) the majority of benthic foraminiferal species survived (Schulte et al., 2010). By the early Eocene, populations of 
planktic foraminifera had recovered and Morozovella, Subbotina and Acarinina were three of the dominant planktic genera in the oceans (Pearson et al., 2005).

\section{Foraminifera at Mead stream}

The first microfossil (foraminifera) samples to be collected from Mead Stream are listed in the GNS Science Fossil Record File and include those collected by Morris (1987). The analysis of these samples provided some details of foraminiferal content but age control and an initial biostratigraphic assessment was completed by Strong et al (Strong et al., 1991; Strong et al., 1995) examining foraminifera, radiolarians and dinoflagellates.

Foraminiferal assemblages through the Lower Marl interval yielded $\geq 90 \%$ planktics including Morozovella, Acarinina and Subbotina and the diversity of foraminifera decreased up-section (Strong et al., 1995). Hollis et al. (2005b) successfully correlated the Mead Stream foraminifera biostratigraphy to local foraminiferal zones despite poorly silicified tests.

\subsubsection{Radiolarians}

Radiolarians are closely related to foraminifera. They are classified as kingdom Protista, phylum Sarcomastigophora, subphylum Sarcodina, class Actinopoda, subclass Radiolaria (Riedel, 1967). Radiolarians typically have a diameter of 100-300 $\mu \mathrm{m}$. Their siliceous opaline test is preserved in marine sediments, although their intricate skeletons are more sensitive to dissolution than some of the other microfossils. They are the most varied group of plankton in the fossil record (Lipps, 1993; De Wever et al., 2003) therefore proving to be a very valuable tool for paleoclimate analysis. For the purposes of this project, radiolarians have been counted but not assigned to genera and species. Instead they will be placed into one of two orders: Spumellaria (spheroidal, ellipsoidal, cylindrical or disk-shaped) or Nassellaria (conicalshaped), both of which contain solid opaline silica skeletons.

\section{Radiolarians applications to biostratigraphy and paleoecology}

Radiolarians are typically found in the upper few hundred meters of marine water masses (Kling, 1998). Their distribution and abundance are predominantly controlled by 
environmental conditions such as the availability of nutrients and ocean temperature. For instance, nutrient-rich belts in the ocean are often abundant in radiolarians and other siliceous microfossils (e.g. diatoms) (De Wever et al., 2002).

\section{Radiolaria in the early Paleogene (southwest Pacific)}

Standard radiolarian zonations are based on low latitude species, but as Mead Stream contains high latitude fauna, a separate zonation was developed for the southwest Pacific region (Hollis, 1993, 1997b, 1997a; Hollis, 2002; Hollis et al., 2005b).

Analyses of assemblages from DSDP Site 277 (Hollis, 1997b) and previous studies of Mead Stream (Hollis, 2006) indicate that radiolarian assemblages decline in numbers and diversity into the early Eocene as temperatures increased. A recovery in populations and diversity followed, coinciding with cooling into the late Eocene (refer to Figure 1.1 for global temperature) and an increase in biogenic opal deposition to reach levels comparable to those observed globally in the Oligocene (Lazarus et al., 2008).

\section{Radiolarians at Mead Stream}

Strong et al. (1995) analysed the radiolarian content of samples for radiolarians from the top of the Amuri Limestone to just below the K/Pg boundary, a thickness of $523 \mathrm{~m}$. An influx of spumellarian radiolarians and diatoms in the early Paleogene indicated an increase in siliceous plankton productivity (Strong et al., 1995). Further investigation by Hollis et al. (2005b) confirmed that radiolarians were common but poorly preserved throughout the upper Mead Hill Formation, Waipawa Formation and Lower Limestone at Mead Stream (middle to latest Paleocene). In the upper part of the Lower Limestone and the Lower Marl (early Eocene), however, radiolarians were generally rare although often well preserved.

The Eocene fauna was typical of a warmer, oligotrophic, subtropical-tropical ocean (Hollis, 2006). The decrease in radiolarian populations and low occurrence of diatoms associated with the EECO suggests a southward expansion of oligotrophic waters in the southwest Pacific (Hollis, 2006). The declining abundance and diversity in the early Eocene corresponded with the occurrence of the EECO and was coupled with a decrease in chert (Hollis, 1997b, 2006). Remarkably, the absence of chert in the southwest Pacific at the time of the EECO - appears to be a local signal as significant deposition of chert coincides with the EECO in equatorial 
regions (Muttoni \& Kent, 2007). Radiolarians continue to be rare but are well preserved in the middle Eocene (Upper Limestone and Upper Marl). The resulting radiolarian succession at Mead Stream forms the basis of a southwest Pacific radiolarian zonation established by Hollis (1997, 2002; Hollis et al. 2005).

\subsubsection{Other microfossils at Mead Stream}

\section{Dinoflagellates}

Dinoflagellates are sporadically present in samples spanning $100 \mathrm{~m}$ above the base of the Mead Hill Formation to the top of the Amuri Limestone (Strong et al., 1995). Only 19 samples were examined by Strong et al. (1995) but the resulting biostratigraphy aligned well with foraminiferal biostratigraphy. Further sampling in later studies revealed that the PETM transition at Mead Stream was barren of dinoflagellates (Hollis et al., 2005b). Waipawan dinoflagelletes were recovered from Lower Limestone and Lower Marl from nearby Bluff and Muzzle sections in the Clarence Valley (Hollis et al., 2005a). A more exhaustive study by Cooper (2018) has been completed in parallel with this project, examining dinoflagellate content in samples from Set A and B.

\section{Diatoms and calcareous nannofossils}

Diatoms are common in the Paleocene at Mead Stream, but rare to very rare in the Eocene (Hollis et al., 2003b; Hollis, 2006).

Samples from Mead Stream were first processed and examined for calcareous nannofossils by Hollis et al. (2005b). Nannofossils were common to abundant in most of the examined samples and although preservation of these specimens was poor to very poor, identification of key index species allowed correlation with international biozones (Figure 3.2).

Agnini prepared additional nannofossil samples in the 2015 Dallanave et al. (2015) study of Mead Stream. In the Lower Marl the assemblages varied, seemingly randomly, from barren or semi barren to highly abundant. Preservation was usually poor in these samples, although the position of several calcareous nannofossil biohorizons was documented and age control further constrained. 


\subsection{Depositional setting of Mead Stream}

Foraminiferal assemblages from the Lower Marl infer deposition at bathyal depths (Strong et al., 1995). Amuri Limestone assemblages consisting of planktic percentages of $90 \%$ or greater and the presence of particular benthic foraminifera species (e.g. Nuttallides carinotruempyi, N. truempyi and "Uvigerina wanzea) indicate an open ocean setting and deposition at a minimum of $500 \mathrm{~m}$ depth, respectively (Strong et al., 1995).

The clay-rich units within the Mead Stream section, prevalent in the Lower Marl, can be explained by a simple model outlined by Slotnick et al. (2012) in Figure 3.4; warm climate of the early Eocene resulted in intensified surface global temperature, sea level rise, precipitation increase and loss of vegetation. These factors led to amplified terrestrial input onto the slope corresponding with the marl facies. Global paleoclimate studies suggest a corresponding major deepening of the $C C D$ (Diagrams $A \rightarrow B$, Figure 3.4) from the Paleocene to the EECO at open ocean sites due to uptake of carbon (Hancock et al., 2007; LeonRodriguez \& Dickens, 2010). This shoaling of the CCD did little to affect carbonate content at Mead Stream due it's shallow position on the continental slope (Figure 3.4B). In contrast, the deep open ocean sites (e.g. Walvis Ridge ODP Site 1262, pictured) were now situated below the CCD and carbonate dissolved resulting in the absence of early Eocene calcareous sedimentary deposits (Slotnick et al., 2012).

In summary, while the increase in occurrence of clay horizons within the Lower Marl could suggest a decrease in carbonate content: the mechanism responsible is in fact terrestrial dilution. The increased Sedimentation Accumulation Rates (SARs) at Mead Stream mentioned later in this chapter support this model. 
This content is unavailable.

Please consult the print version for access.

Figure 3.4: Lithological and geochemical reconstruction of early Eocene conditions at Mead Stream. Note the location of Mead Stream and the likely effect $(A \rightarrow B)$ of high global surface temperature and increased carbon input during hyperthermals on both deep sea and continental margin settings (Slotnick et al., 2012).

\subsection{Integrated Age Control}

Integrated paleontological analysis from Strong et al. (1995) determined that the Mead Hill Formation and Amuri Limestone at Mead Steam spanned the Haumurian - Bortonian New Zealand Stages (Late Cretaceous-middle Eocene). Age control was refined over the following two decades with integrated paleontological and geochemical analysis (Hollis et al., 2005a; Hollis et al., 2005b; Hollis, 2006; Nicolo et al., 2007; Slotnick et al., 2012). The 
recent study by Dallanave et al. (2015) combined this earlier work with geochemistry, magnetostratigraphy, and further biostratigraphy to provide a comprehensive summary of the work to date at Mead Stream;

\section{Lower Limestone to Upper Marl (late Paleocene to early Eocene)}

Foraminiferal coverage spanned much of the section, from the base of the Mead Hill Formation ( $0 \mathrm{~m}$ datum) through the top of the Amuri Limestone $(523 \mathrm{~m}$ ) despite a $75 \mathrm{~m}$ sample gap in the Upper Marl (Strong et al., 1995). Analysis of the foraminifera assemblages indicated that the Lower Marl was within the Waipawan-Bortonian Stages (56.0-39.1 Ma) (Strong et al., 1995).

Hollis et al. (2005b) examined newly and previously collected foraminifera samples in order to increase resolution and concentrate on the PETM and EECO events at Mead Stream. The resulting planktic foraminifera for the Lower Marl are shown in Figure 3.5, along with calcareous nannofossil and radiolarian zones and New Zealand stages. 


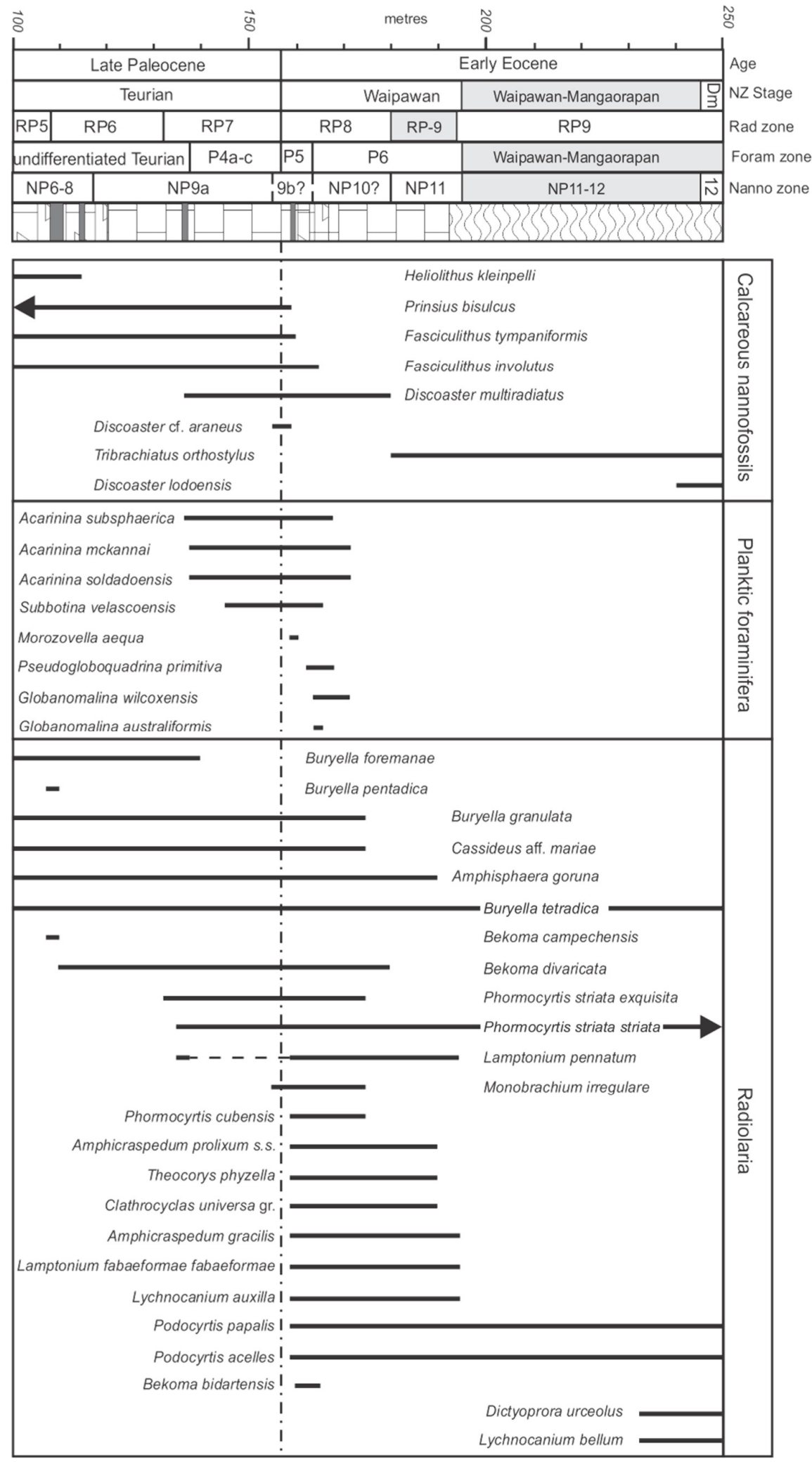

Figure 3.5 Upper Paleocene-lower Eocene biostratigraphy at Mead Stream spanning 100$250 \mathrm{~m}$ above the $\mathrm{K} / \mathrm{Pg}$ boundary (Hollis et al., 2005b). 
Dallanave et al. (2015) examined previously collected foraminifera samples spanning the Lower to Upper Marl of Mead Stream (257.9-399 m). Residues processed from directly above the base of the Lower Marl contained Morozovella lensiformis and Globigerina triloculinoides, indicating that this part of the section was either Waipawan or early Mangaorapan in age. The location of the Waipawan-Mangorapan boundary was identified based on the first occurrence of Morozovella crater between 260.9 and $263 \mathrm{~m}$. This boundary lies immediately below a deformed zone (265-279 above the K/Pg boundary) within the Lower Marl (Dallanave et al., 2015).

Magnetostratigraphy measures the polarity of the earth at the time of deposition, therefore providing an independent dating mechanism for sedimentary rocks and deep-sea cores. Mead Stream is an excellent candidate for magnetostratigraphy because it provides the most uninterrupted, and expanded record of continental shelf deposition known in the southwest Pacific during the early Eocene (Dallanave et al., 2015). The study by Dallanave et al. (2015) successfully integrated magnetostratigraphy with biostratigraphy and carbon isotope stratigraphy to present an age model through the Eocene at Mead Stream. This study aligned magnetostratigraphic data from the Mead Stream section, open ocean cores and other onshore sections settings. Figure 3.6 presents a detailed Age-depth model from this study in which Sedimentation Accumulation Rates (SARs) are calculated. The rate of deposition increased from $16 \mathrm{~m} / \mathrm{myr}$ in the Lower Limestone to a maximum of $43 \mathrm{~m} / \mathrm{myr}$ in the Lower Marl. In alignment with Slotnick et al. (2012), results indicated an increase in sedimentation rates at approximately $52 \mathrm{Ma}$ corresponding with the EECO. Both studies support the model of warmer climate and a consequential increased hydrological cycle and terrestrial run-off onto the continental slope (Slotnick et al., 2012). 
This content is unavailable.

Please consult the print version for access.

Figure 3.6: Age-Depth Model for Mead Stream including microfossil biohorizons. Modified from Dallanave et al (2015).

Smectite is the dominant clay mineral within the marls at Mead Stream. (Fergusson, 1985; Morris, 1987). The dominance of smectite suggests a climate with contrasting seasons and a pronounced dry season (Singer, 1984), indicating increased weathering under warm and tropical conditions (Fagel, 2007). This presence of smectite in the EECO within the Lower Marl where SARs are highest is therefore additional evidence for an increase in chemical weathering, resulting in an increased terrigenous sediment supply to the continental shelf at Mead Stream (Dallanave et al., 2015).

It is possible that the transition from the Lower Marl in to the Upper Limestone may signal the termination of the EECO (Hollis et al., 2005b; Slotnick et al., 2012) however further work is needed to support this observation. 


\subsection{Examination of other Muzzle Group sites}

Hollis et al. (2005a) summarised paleontological data from two associated sections in the Clarence Valley, which led to further refinement of the biostratigraphy of the Muzzle Group. Examination of foraminifera, dinoflagellate cysts, calcareous nannofossils, radiolarians and carbon isotopic data from nearby Muzzle and Bluff Streams showed that the marl-rich facies of the Lower Marl corresponded with the EECO and was present throughout the Marlborough sub-basin. Similar to Mead Stream, planktic foraminifera dominated assemblages from Muzzle and Bluff Streams. Lower Marl assemblages are inferred to be early to late Waipawan in age, due to the presence of Acarinina subshaerica. Mid-bathyal depths were inferred in these Muzzle Stream sections during the Paleogene due to the presence of Osangularia, Vulvulina, Nuttalides, Anomalina and various deep water Cibicides benthic foraminifera species (Hollis et al., 2005a). The foraminiferal tests from Muzzle and Bluff streams were poorly preserved due to recrystallisation and calcite overgrowth (Strong et al., 1995; Hollis et al., 2005a)

\subsection{Integration of geochemistry and paleontology}

Previous studies of Mead Stream indicate that deposition on the continental shelf occurred during times of change in climate and carbon cycling (Hollis et al., 2005b; Slotnick et al., 2012; Dallanave et al., 2015). Therefore, geochemistry and magnetostratigraphy integrated with paleontology not only provided calibration with global events and further age control, but offer insights into paleoenvironmental and paleoclimatic conditions;

\section{Expression of the EECO at Mead Stream}

$\mathrm{A} \sim 1 \%$ negative $\mathrm{CIE}$ and a transition from limestone-rich to marl-rich facies corresponded with the significant decrease in radiolarian abundance in the early Eocene mentioned earlier (Hollis et al., 2005b). This provides further evidence of the onset of the EECO at the base of the Lower Marl, occurring at approximately $53 \mathrm{Ma}$ (Hollis et al., 2005b). Alignment with a long term decrease in $\delta^{13} \mathrm{C}$ in global records, shows that the J CIE occurs, between $206.5 \mathrm{~m}$ and $207.83 \mathrm{~m}$ at Mead Stream, just after this change in facies (Slotnick et al., 2012). Carbon isotopes and biostratigraphy nearby Bluff and Muzzle Streams (Hollis et al., 2005a; Hollis et 
al., 2005b) confirm that Lower Marl represents the main phase of the EECO in these associated outcrops.

\section{Expression of CIEs at Mead Stream}

Analysis of both carbon and oxygen isotopes at Mead Stream was initially completed by Hollis et al. (2005b). This was further supplemented by Nicolo et al. (2007) and Slotnick et al. (2012) who combined calcium carbonate $\left(\mathrm{CaCO}_{3}\right)$ content and $\delta^{13} \mathrm{C}$ values to provide correlation with global expressions of the early Eocene CIEs;

Oxygen isotope results were disregarded because bulk carbonate $\delta^{18} \mathrm{O}$ values are likely to have been affected by meteoric waters (Hancock et al., 2003; Hollis et al., 2005a). Samples from Mead Stream ( 170-200 m above the K/Pg boundary), together with nearby Dee Stream, confirmed that five global events - the PETM and hyperthermals $\mathrm{H}-1$ (ELMO), $\mathrm{H}-2, \mathrm{I}-$ 1 and I-2 - were present in the Clarence Valley (Nicolo et al., 2007). The $\delta^{13} \mathrm{C}$ excursion was expressed in both marl and limestones suggesting a primary carbonate signal.

Sedimentation rates were elevated at each of the CIEs, the largest increase observed at the PETM. The results were in contrast to ocean open settings in which sedimentation rates decreased due to carbon dissolution in the deep marine environments during these events (e.g. Ocean Drilling Programme (ODP) Site 1262; (Nicolo et al., 2007).

A later study by Slotnick (2012), examined the $\delta^{13} \mathrm{C}$ record at Mead Stream from an interval 130-270 $\mathrm{m}$ above the K/Pg boundary (spanning Lower Limestone to Lower Marl). This record was correlated with intervals encompassing the PETM and early hyperthermals $(\mathrm{H}-1$, H-2, I-1 and I-2) in deep sea cores from ODP Sites 577 (north Pacific Shatsky Rise) and 1262 (south Atlantic Walvis Ridge) (Figure 3.7) (Slotnick et al., 2012). Further to the five events within the Lower Limestone at Mead Stream described by Nicolo (2007), four additional CIEs were identified (in stratigraphic order) - the ' $\mathrm{J}$ ', ' $\mathrm{K}$ ' and two possible ' $\mathrm{L}$ ' events (Figure 3.7). At the transition from Lower Limestone into Lower Marl, a $0.3 \%$ drop in $\delta^{13} \mathrm{C}$ likely corresponds with the ' $\mathrm{J}$ ' event. The next significant negative CIE observed at $222 \mathrm{~m}$ corresponds with the ' $\mathrm{K}$ ' or ' $\mathrm{X}$ ' CIEs. The ' $\mathrm{K}$ ' or ' $\mathrm{X}$ ' event exhibits the most pronounced excursion of the three events of interest have been documented in the northern hemisphere (e.g. Agnini et al., 2009). The 'L' global event (defined by Cramer et al., 2003) is 
likely to be expressed locally via one or two negative $\delta^{13} \mathrm{C}$ values that occur between 235 and $243 \mathrm{~m}$. Slotnick et al. (2012) noted that there may be additional associated hyperthermals within the EECO - (see the enlarged carbon isotopic curve on right of diagram in Figure 3.7). 
This content is unavailable.

Please consult the print version for access.

Figure 3.7 Microfossil zones, lithostratigraphy and carbon isotopes from 100-325 m of the Mead Stream section (modified from Slotnick et al. (2012). The EECO is roughly defined by the green shading. $\delta^{13} \mathrm{C}$ correlation with deep sea drilling records is on the right. CIE's are shaded in grey. 


\subsection{Orbital forcing}

Overseas studies have suggested a relationship between rhythmically bedded clay rich intervals and orbital frequencies (e.g. Meyers et al., 2001; Eldrett et al., 2015). Although individual bed thickness within the Mead Stream section does not correspond to orbital forcing the cyclical nature of the sediment has been related to Milankovitch cycles (Hollis et al., 2005b); clusters of beds within the Lower Limestone (late Paleocene-early Eocene) indicate cycles of precession (23 kyr), obliquity (41 kyr) and eccentricity (100 kyr) are present (Figure 3.8). Furthermore, a 100 kyr lapse between CIEs is observed at Mead Stream (Nicolo et al., 2007). Additional high-resolution studies spanning multiple beds in the Lower Marl are necessary to investigate if the marl-limestone alternations may relate to Milankovitch precession cycles.

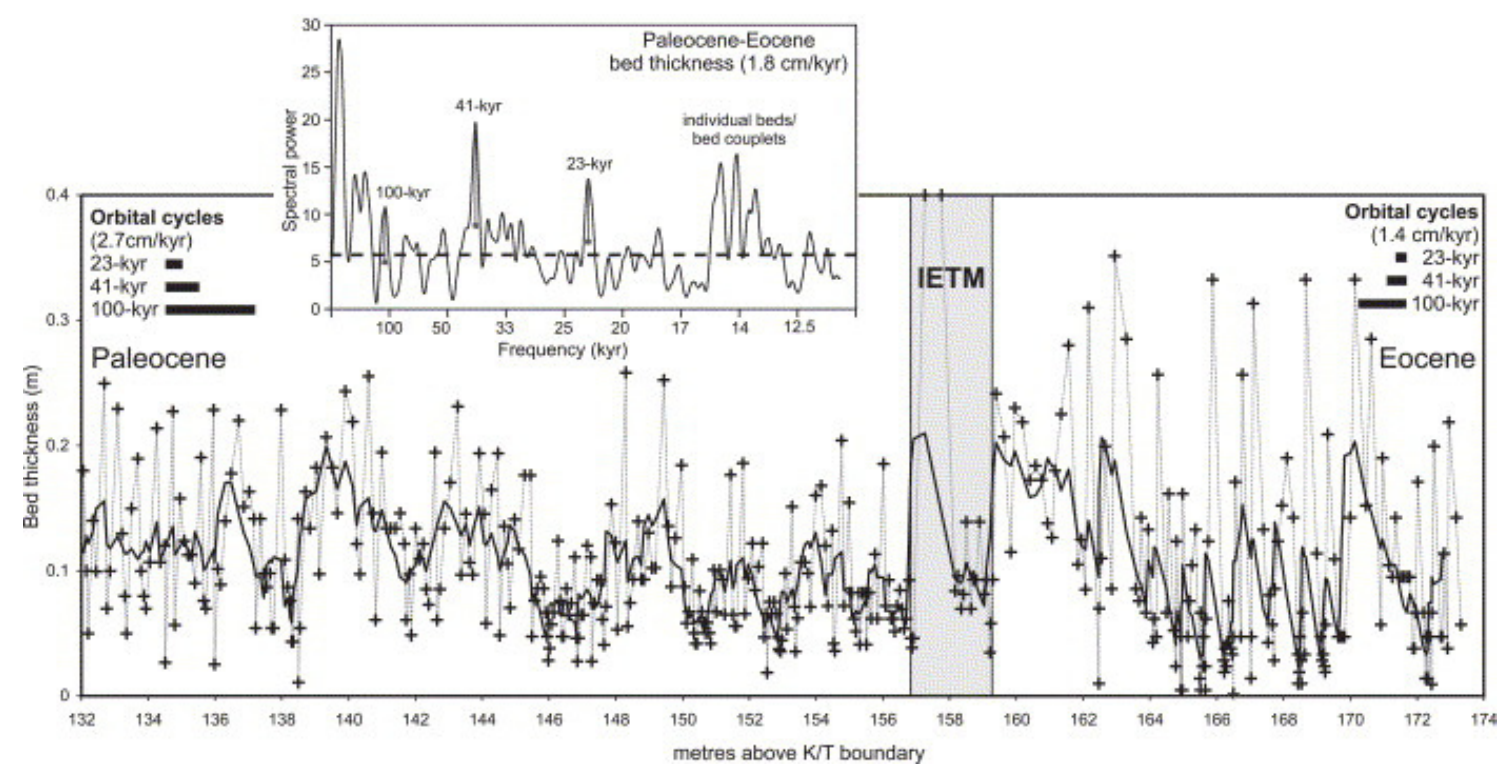

Figure 3.8 Variation in bed thickness in Lower Limestone of Mead Stream associated with Milankovitch cycles (Hollis et al., 2005b). 


\section{CHAPTER 4 - METHODS:}

\subsection{Sample collection and nomenclature}

This study is based on 3 sets of samples (listed in Appendix A). The main focus is on the results of two high resolution sample sets (denoted Sets A and B). The third a lowresolution historical sample set (Trial Set) was used during the initial phases of this study to evaluate the effectiveness of the acetic acid leaching method. Each of the 3 sets consists of samples collected from alternating limestone and marl lithology. Only marl samples were processed for foraminifera in previous studies (Morris, 1987; Strong et al., 1995; Hollis et al., 2005a; Hollis et al., 2005b; Dallanave et al., 2015).

Limestone beds from the Lower Marl at Mead Stream have been numbered L1-L114 in previous studies and the sub-beds sampled in this study utilise the same nomenclature;

followed by a further sub-bed number e.g. L1/1. Marl samples have been labelled using the subsequent limestone bed number and /M, e.g. L1/M/1 (refer to Figures 4.1, 4.4 and 4.6 for clarification). Stratigraphic height refers to the top of beds and is based on the most recent section log by Crampton, 2015. Stratigraphic heights are given relative to the $\mathrm{K} / \mathrm{Pg}$ boundary, as determined in previous studies (Strong et al., 1995; Hollis et al., 2005b; Slotnick et al., 2012; Dallanave et al., 2015). The Trial Set were collected over several field seasons and were obtained from the GNS bulk paleontological collection. Sets A and B were collected at Mead Stream in December 2015 by Bermudez and Cooper for this project. 


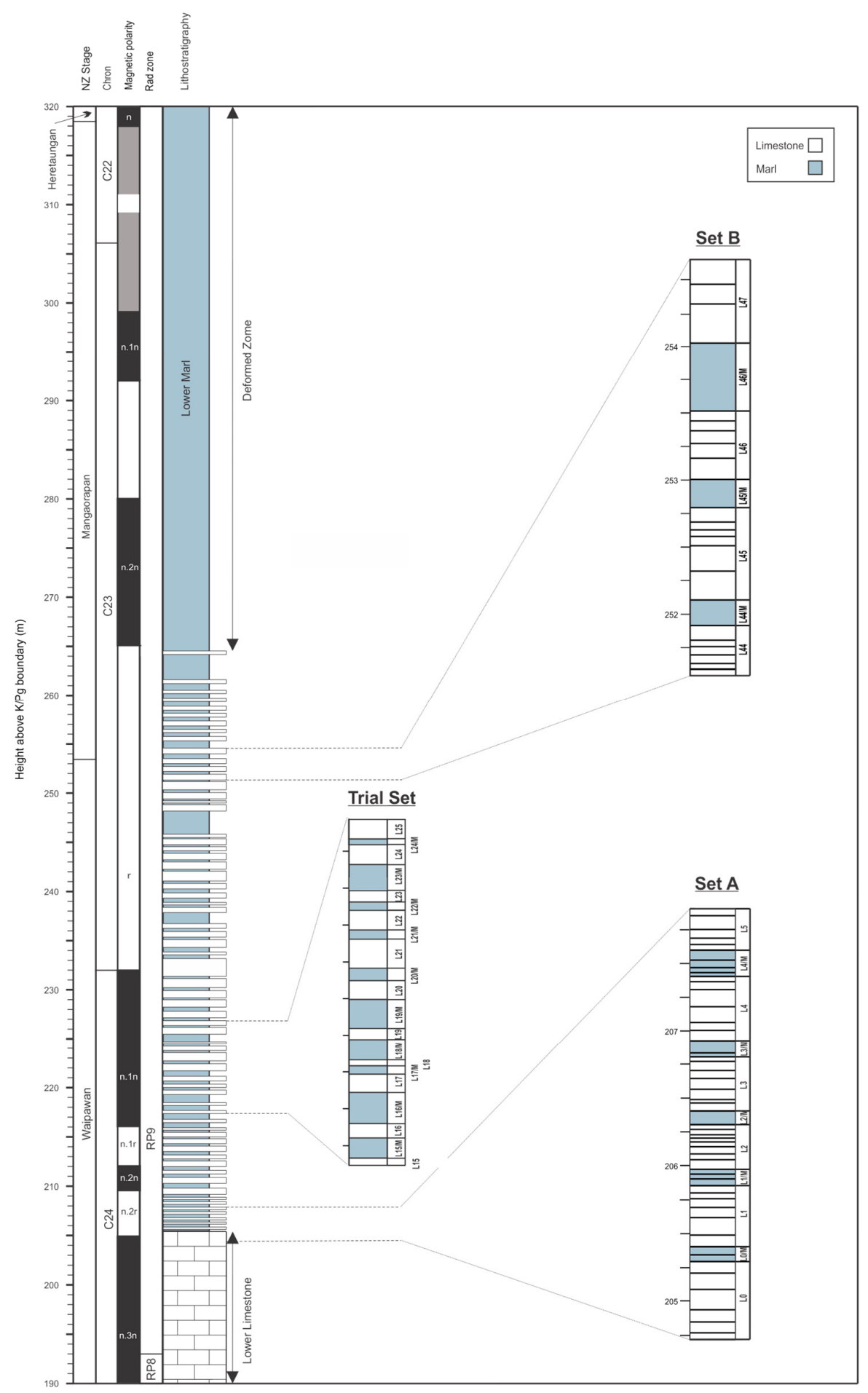

Figure 4.1 Lower Marl of the Amuri Limestone of Mead Stream, showing the position of the Trial, $A$ and $B$ sample sets within the section. Note the numbering of limestone and marl sub-beds encompassed within beds. NZMG 25757795916039 - NZMG 25756295916069. 
All three sample sets were collected from the Lower Marl and details of each set are as follows (NZMG 25757405916050 - NZMG 2575739 5916019):

- Trial Set

A suite of 21 medium-resolution (15 cm spacing on average) samples from the GNS bulk paleontology collection spanning the ' $\mathrm{K}$ ' $\mathrm{CIE}$ was processed as a trial for the glacial acetic acid processing method. This suite includes marls that have been processed previously using the standard sieving technique. The sample set (Figure 4.2) consists of samples spanning 217.52 to 226.41 m (beds L15-L25). 


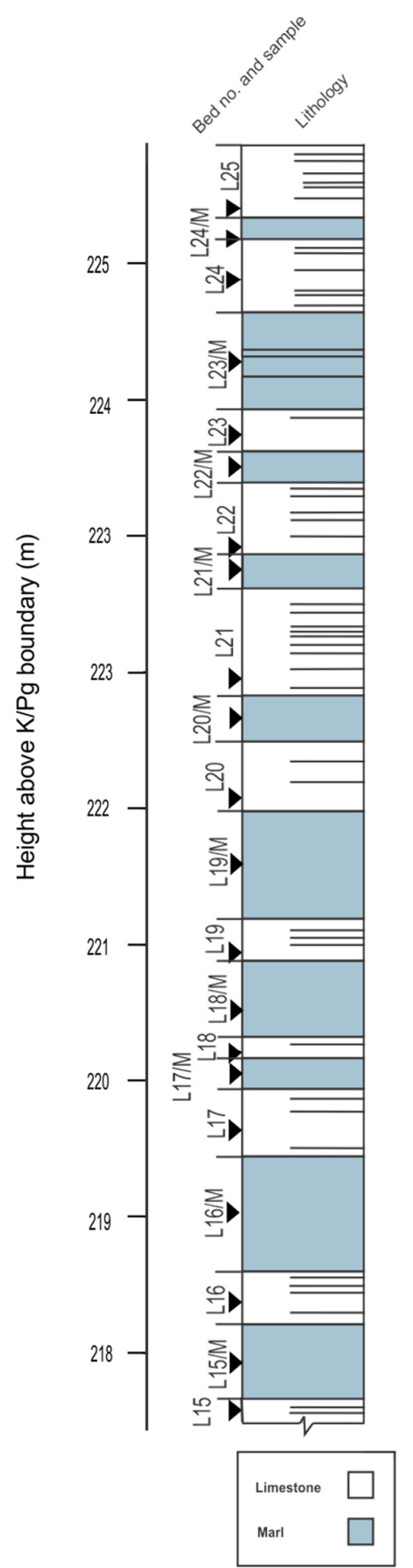

Figure 4.2: Trial Set samples from 217.52-226.41 m of the Lower Marl at Mead Stream. Beds L15-L25 have been at height indicated by an arrow in previous studies. Black lines within beds denote presence of sub-bedding. NZMG 25757395916019. 
- Set A

A suite of 51 high-resolution ( $8 \mathrm{~cm}$ spacing on average) samples, starting at the Lower Limestone-Lower Marl transition and including the J CIE. These samples are logged from 204.715 to 207.900 m (sub-beds L0/1-L5/5 (Figures 4.3, 4.4).

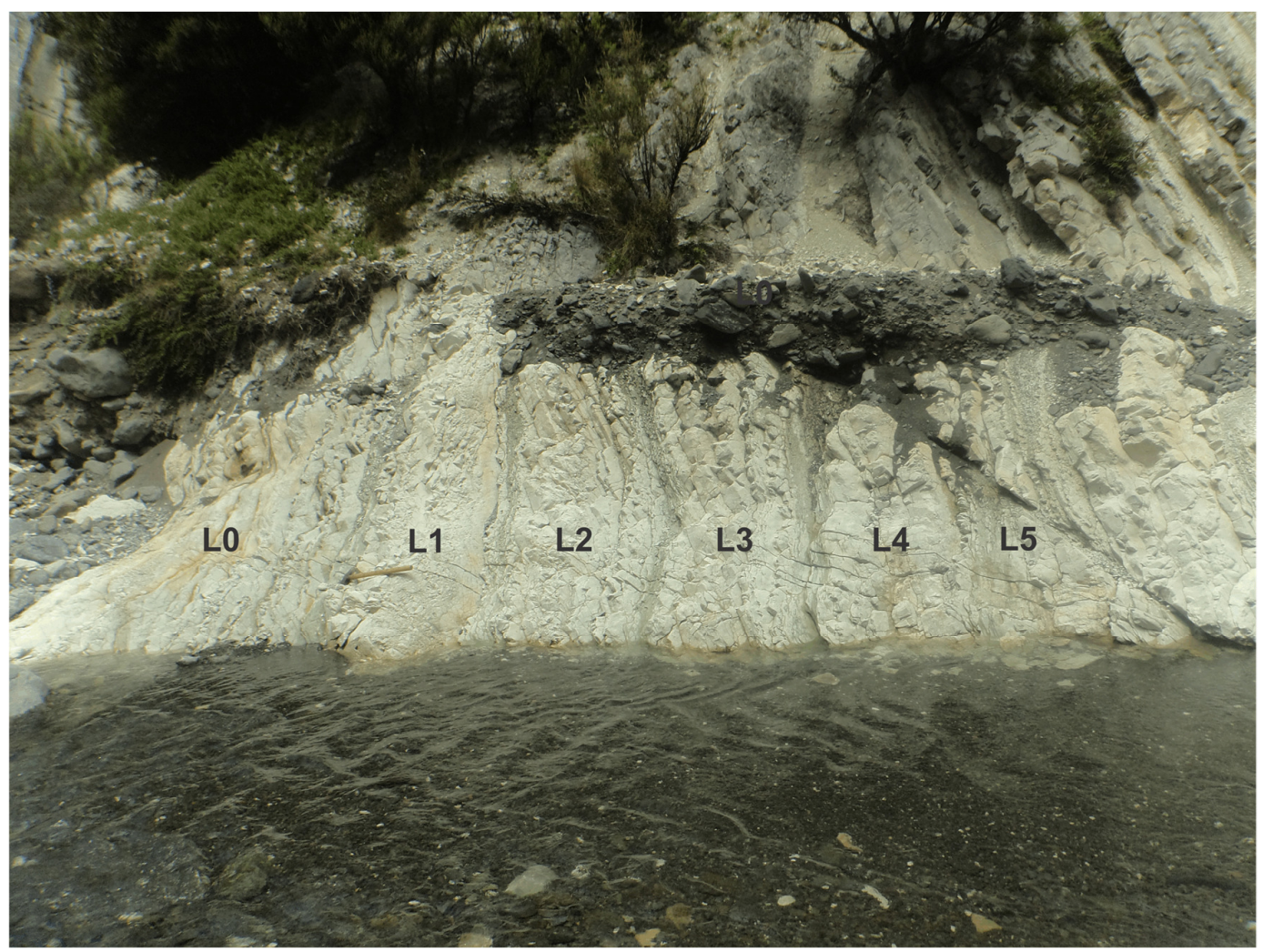

Figure 4.3: Set A Limestone and marl beds from 204.715-207.900 m (sub-beds LO-L5) in the Lower Marl, Mead Stream. Within each numbered 'L' limestone bed multiple sub-beds were extracted for this high-resolution study. Each limestone is overlain by a darker and thinner marl bed. Rock hammer $(60 \mathrm{~cm})$ is for scale. 


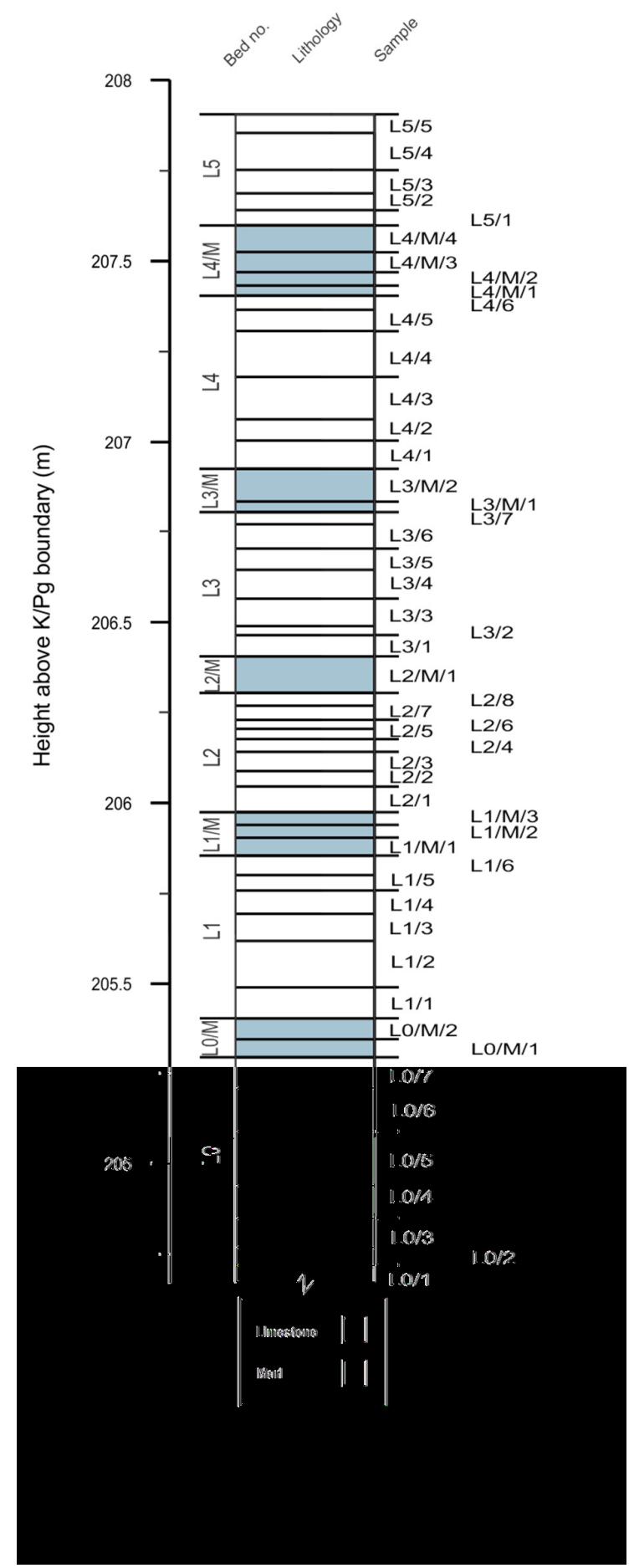

Figure 4.4: Set A samples from 204.715-207.900 m (LO/1-L5/5) of the Lower Marl at Mead Stream. Bed numbers are on the left and sub-bed samples from this study are on the right. Each sample consists of material collected across the entire sub-bed. NZMG 2575740 5916050 - NZMG 25757495916019. 
- Set B

A second high-resolution suite of 24 samples was collected from 251.573 to 254.640 $\mathrm{m}$ and labelled as sub-beds L44/1-L47/3 (Figure 4.5 and 4.6). This sample set includes the Waipawan-Mangaorapan (Dw-Dm) boundary.

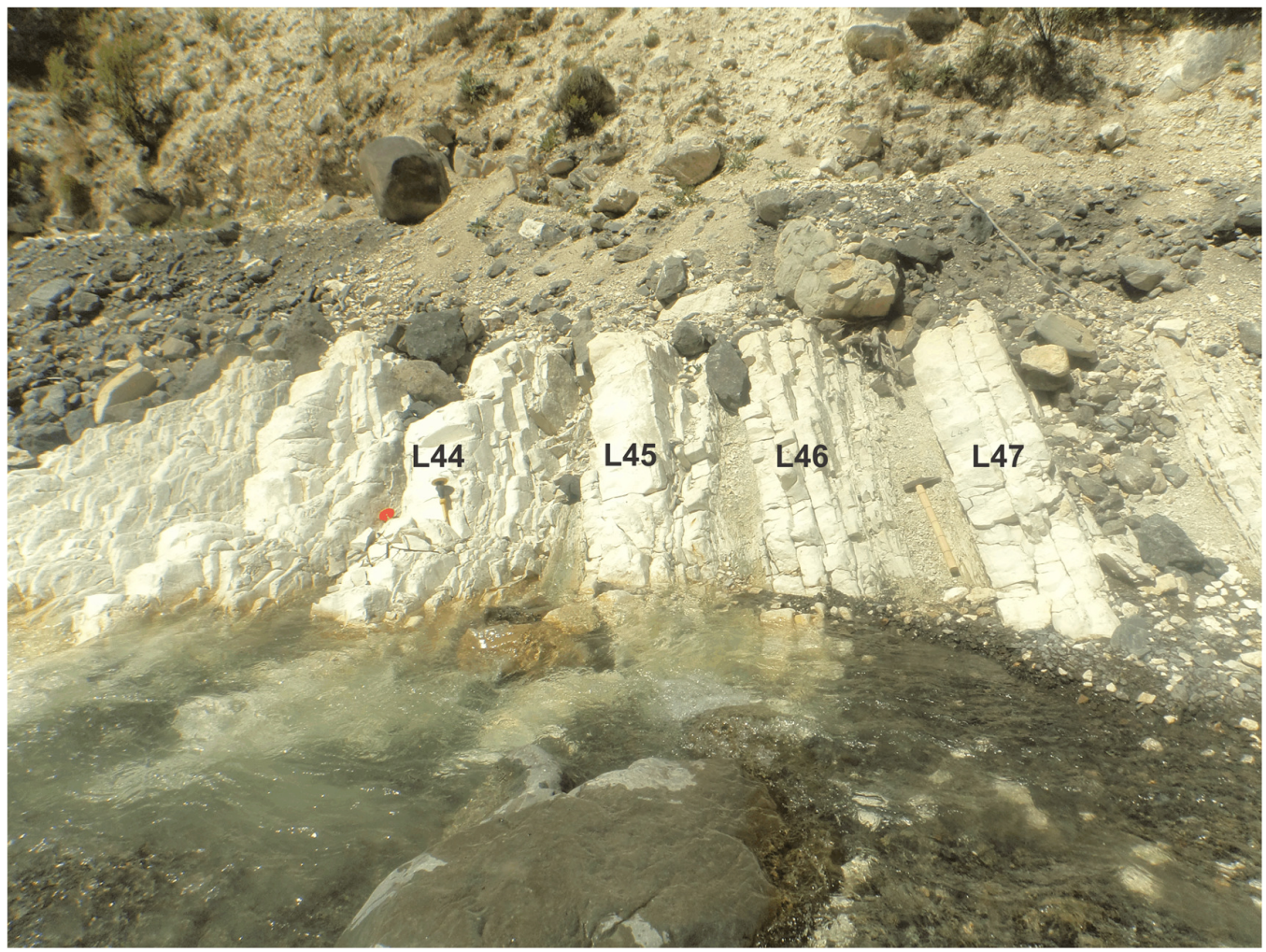

Figure 4.5: Limestone and marl beds of Set B spanning 251.573-254.640 m (sub-beds L44L47) in the Lower Marl, Mead Stream. Note that the marls are thicker in this upper part of the Lower Marl in comparison to those in Figure 4.2. Rock hammer $(60 \mathrm{~cm})$ is for scale. 


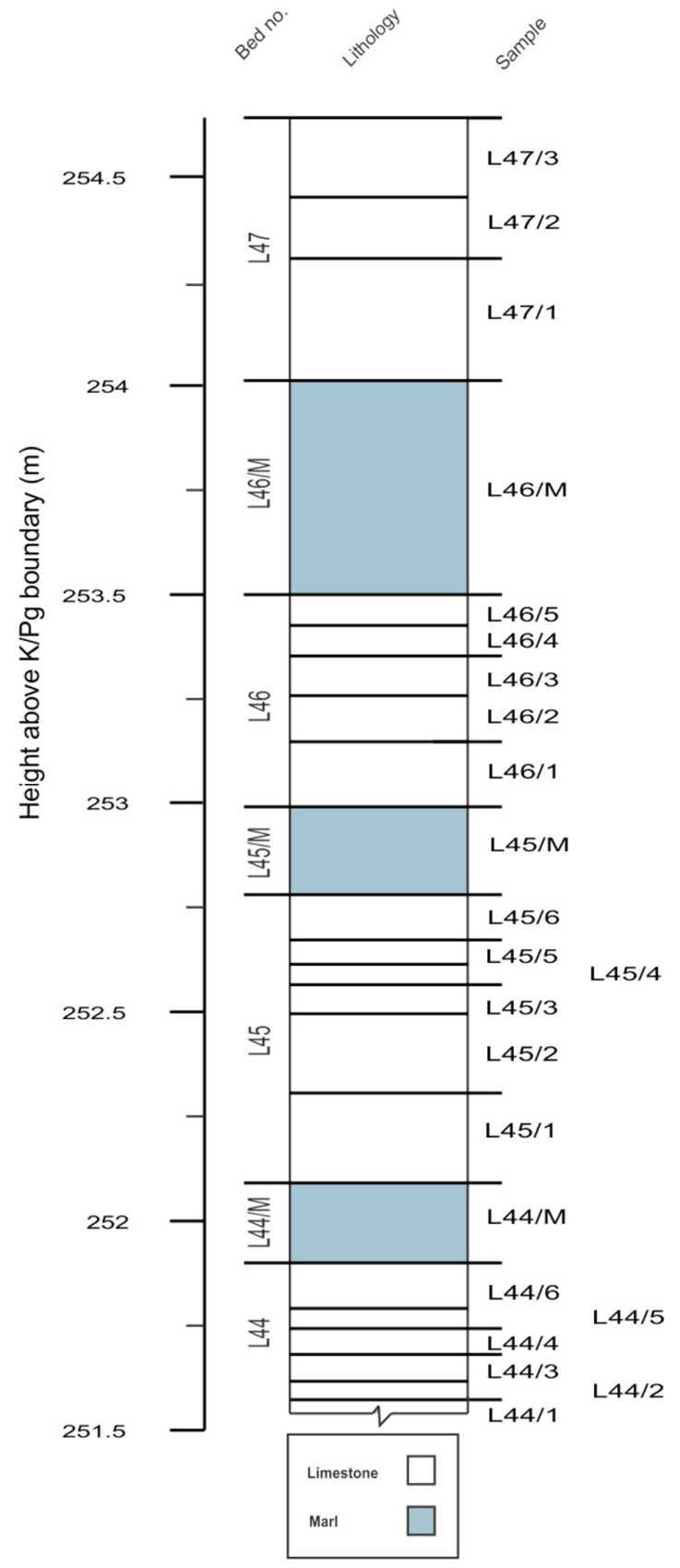

Figure 4.6: Set B samples from 251.573-254.640 m (L44/1-L47/3) of the Lower Marl at Mead Stream. Bed numbers are on the left and sub-bed samples from this study are on the right. Each sample consists of material collected across the entire sub-bed. NZMG 2575739 5916019. 
Beds were identified using unpublished photographs and stratigraphic log (J.Crampton pers. comm 2011) For the limestones, a Stihl TS500i cut-off (rock) saw was used to cut perpendicular to the bedding to facilitate collection of a continuous sample set across the entire limestone bed (Figure 4.7). Each bed was divided into smaller sub-beds, resulting in an average of 6 sub-beds per limestone bed. The orientation of the samples was recorded to ensure the entire bed was captured, except for the marls and a few softer 'marly' limestones. Here, where the soft lithology did not allow uniform removal of an entire block, a representative sample was taken throughout the sub-bed. The marls were recessed in the outcrop due to their softer composition and were sampled using a pick and rock hammer. All the marl sub-beds in Set B consist of a single sample.
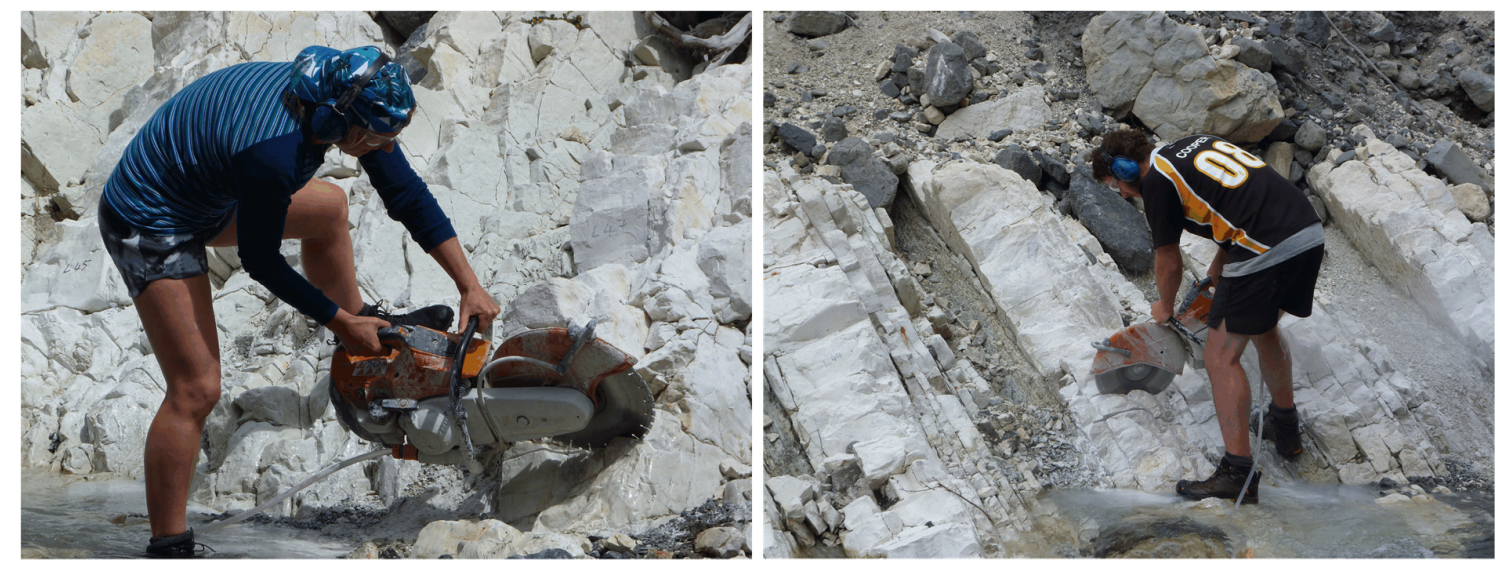

Figure 4.7: Cutting beds L44-L47 of the Lower Marl Amuri Limestone using the rock saw, Mead Stream.

\subsection{Sample preparation}

Limestones were removed in blocks, allowing their orientation to be recorded (Figure 4.8A). Marls were soft and often broke up on removal. As a result, multiple pieces were required to span the sub-bed. Sometimes orientation was possible (B) but the majority of the time the marl crumbled into many pieces (C). 


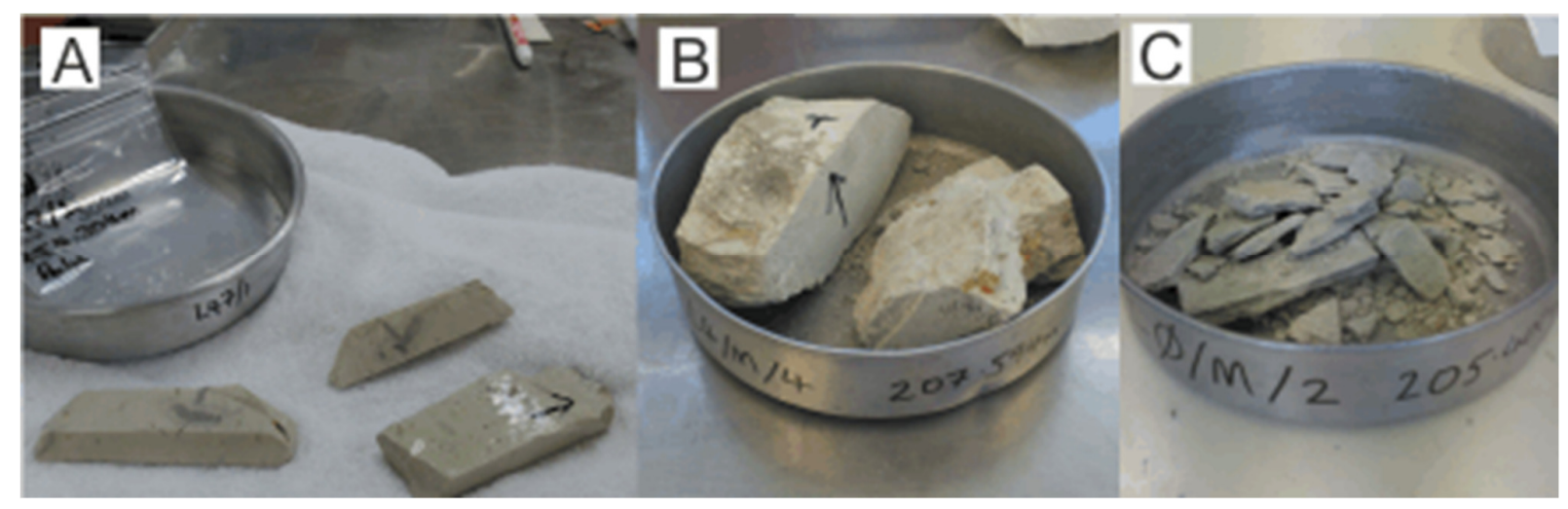

Figure 4.8 Samples of the Lower Marl pre-processing. Large orientated blocks of limestone (A), intact orientated blocks of marl (B) and fragmented pieces of marl (C).

\subsubsection{Marls}

Approximately $200 \mathrm{~g}$ of marl was dried, crushed and dry-sieved through a nest of $5.60 \mathrm{~mm}$ and $3.15 \mathrm{~mm}$ sieves. Fragments bigger than $5.60 \mathrm{~mm}$ were re-crushed so that all sample fragments passed through the sieve. The $3.15-5.60 \mathrm{~mm}$ fraction was split resulting in $60-80$ $\mathrm{g}$ of sediment available for foraminifera analysis. The material less than $3.15 \mathrm{~mm}$ was set aside for palynology.

\subsubsection{Limestones}

Approximately $80-150 \mathrm{~g}$ of limestone was sectioned by making multiple slices perpendicular to the bedding plane, in order to obtain a $20-40 \mathrm{~g}$ sample for foraminifera and where required, an 80-100 g sample for palynology. These samples were then dried in the oven at $40^{\circ} \mathrm{C}$.

For both lithologies pieces of leftover rock from microfossil preparation were set in a clean tray and dried in the oven at $40^{\circ}$. Then the tungsten carbide mill was used to mill approximately $35 \mathrm{~g}$ of both marl and limestone to fine powder $(<250 \mu \mathrm{m})$. The powder was packed into small vials and sealed with cling film and a rubber band ready for stable isotope analysis followed by XRF. 


\subsection{XRF and Stable Isotope analysis}

For X-ray fluorescence (XRF) the sample sets $A$ and $B$ were scanned using a hand-held Olympus Delta 50 Series Portable XRF Analyser using an X-ray Rh/Ag Tube (10-50kVp 10 $200 \mu \mathrm{A})$. Vials were exposed to the XRF gun for 90 seconds using the GEOCHEM setting in conjunction with the ActiveSync software application. Major elements in the GEOCHEM detection list included Silica, Calcium, Iron, Aluminium, and Barium. Silica Oxide blanks and Standards were scanned every 20 samples (minimum) and to ensure reproducibility. Each sample was measured twice with the handheld XRF unit, creating a duplicate sample. Averages of the original and duplicate values were used for data analysis.

These same sample splits were then transferred to a pottle and analysed for $\delta^{13} \mathrm{C}$ and $\delta^{18} \mathrm{O}$ at the GNS Science Stable Isotope Laboratory. Isotopes were analysed on the GVI IsoPrime Carbonate Preparation System at a reaction temperature of $25^{\circ} \mathrm{C}$ for 24 hours and run via dual inlet on the IsoPrime mass spectrometer. Carbonate was removed in a low-pressure automated system using hydrochloric acid. All results were normalized to the GNS Marble internal standard with reported values of $2.04 \%$ for $\delta^{13} \mathrm{C}$ and $-6.40 \%$ for $\delta^{18} \mathrm{O}$. The external precision for these measurements are better than $0.1 \%$ for $\delta^{13} \mathrm{C}$ and $0.2 \%$ for $\delta^{18} \mathrm{O}$. When collating and comparing this data with previous data (Slotnick et al., 2012), depths that resulted in a 'non-detected' reading were removed from the plots. Note that only L44/6B was sampled for XRF (L44/6A was not recorded).

Excess silica ( $\mathrm{Si}\left[\right.$ excess]), calcium carbonate $\left(\mathrm{CaCO}_{3}\right)$ and terrigenous (TRG) content were calculated using normative equations and maximum and minimum compound values from Hollis et. al (2003b) as follows:

\section{Excess Silica}

$\mathrm{Si}[$ excess $]=\mathrm{SiO}_{2}-\left(\mathrm{Al}_{2} \mathrm{O}_{3} \times 70[\mathrm{MBKT}] / 16.5[\mathrm{MD}]\right)$

Where:

$\mathrm{SiO}_{2}=$ percentage of $\mathrm{SiO} 2$ in the sample

$\mathrm{Al}_{2} \mathrm{O}_{3}=$ percentage of $\mathrm{Al} 2 \mathrm{O} 3$ in the sample

$70[\mathrm{MBKT}]=$ the average percentage $\mathrm{Al} 2 \mathrm{O} 3$ found in the Marlborough K/T Boundary Sections $16.5[\mathrm{MD}]=$ the maximum Al203 percentage for Mead Stream 


\section{Calcium Carbonate}

$\mathrm{CaCO}_{3}=\mathrm{CaO} \times(100 / 56)-\left(\mathrm{Al}_{2} \mathrm{O}_{3} \times 0.2[\mathrm{MBKT}] / 16.5[\mathrm{MD}]\right)$

Where:

$\mathrm{CaO}=$ the percentage of $\mathrm{CaO}$ in the sample

$100 / 56=$ the atomic ratio of $\mathrm{CaCO}_{3} / \mathrm{CaO}$

$0.2[\mathrm{MBKT}]=$ total minimum bulk $\mathrm{CaCO}_{3}$ found in the Marlborough $\mathrm{K} / \mathrm{T}$ Boundary

\section{Terrigenous sediment}

$T R G=\mathrm{Al}_{2} \mathrm{O}_{3} / 16.5[\mathrm{MD}]^{*} 100$

The sum of Si[excess], $\mathrm{CaCO} 3$ and TRG did not equal 100\%, due to unknown volatile components which were incorporated into the Lost On Ignition (LOI) category. Therefore, the three components (\%TRG, Si[excess] and \%Ca) were recalculated to 100 . This resulted in $\mathrm{CaCO}_{3}$ values that were consistent with measurements reported by Slotnick et al. (2012).

\subsection{Microfossil processing and analysis}

The processing of limestones to extract identifiable foraminifera has been a trial and error method and modifications and/or improvements to the technique form a significant part of this thesis.

As mentioned in Chapter 3, the indurated limestones required acid treatment to dissolve the calcareous matrix and release the microfossils. Hydrochloric acid leaches calcium carbonate vigorously whereas acetic acid is a weaker acid and breaks down the limestone at a slower rate. Acetic acid still may damage the microfossils over a prolonged period but the acid breaks bonds at their weakest points where the matrix meets the microfossil. The eventual disintegration of microfossils is kept to a minimum by regulating exposure time. Whilst noting that this method produces very clean microfossils, Reolid \& Herrero (2004) suggest there is a possible loss of foraminifera internal moulds and comparison with thin sections is recommended. Therefore, some cross-checking with thin sections has been included for the Trial Set in the initial stages of this study. 
The reaction between acetic acid and limestone results in the production of calcium acetate, carbon dioxide and water:

$$
\mathrm{CaCO}_{3}+2 \mathrm{CH}_{3} \mathrm{COOH}-->\mathrm{Ca}\left(\mathrm{CH}_{3} \mathrm{COO}\right)_{2}+\mathrm{H} 2 \mathrm{O}+\mathrm{CO}_{2}
$$

Full strength acetic acid will not work so the reaction requires the acetic acid to be diluted with water in order to produce the hydrogen ions required to initiate the reaction. Therefore, an $80 \%$ solution was used on all samples. The crushed sample is immersed in this solution for a variable number of hours (to be explained in Chapter 5 ) in a fume hood with a watch glass on top to minimise evaporation of the liquid. If microscopic examination confirmed that fossils needed further cleaning, then ultrasonic treatment was carried out. The method chosen for the extraction of limestones and the percentage of acid dilution are both experimental and use Lirer's (2000) basic technique using $80 \%$ acetic acid, as illustrated in Figure 4.9 and described below (for each of the lithologies). The acetic acid leaching method has been applied to the marls throughout this study, for consistency.

Previous studies by Luciani et al. (2007) have shown that no particular genera of foraminifera from the early Eocene were preferentially dissolved when comparing the acid leaching technique to standard methods of washing and sieving, therefore similar experiments were not replicated in this study. 
This content is unavailable.

Please consult the print version for access.

Figure 4.9: Acetic acid method for leaching of limestones (Lirer, 2000). Samples are crushed using a rock hammer into small chips and then immersed in acetic acid. Sieving and drying is followed by ultrasonic treatment (if necessary). Residues are examined under the microscope to ensure no further processing or cleaning is necessary. Modifications to this method are referred to in the text. 


\subsubsection{Marls}

A representative sample of approximately $10 \mathrm{~g}$ was immersed in $80 \%$ acetic acid in a beaker with a watch glass on top within the safety of the fume hood. Exposure times varied from 4-12 hours (see Chapter 5) when the supernatant frothed and finer sediment started to appear at the bottom of the beaker. Following acid digestion, the sample was rinsed thoroughly over a $63 \mu \mathrm{m}$ sieve and dried in the oven at $40^{\circ} \mathrm{C}$. The dried sample was then boiled with water and Calgon detergent. $30 \%$ hydrogen peroxide was added to the solution at approximately $90^{\circ} \mathrm{C}\left(160^{\circ}\right.$ setting on the hotplate) and simmered gently for 1--2 hours inside a fume hood. Dried material less than $500 \mu \mathrm{m}$ was examined under a stereo microscope and the peroxide/Calgon wash was repeated if necessary (sometimes 2-3 times) to obtain clean samples. The dry residue was put through a microsplitter to obtain the appropriate amount of material for picking 100 foraminifera specimens.

\subsubsection{Limestones}

Selected samples were crushed as little as possible whilst ensuring that no chips were greater than $5.60 \mathrm{~mm}$. A representative sample of 10-20 g from all sample sets was taken using the splitter and dry-sieved. The resulting 3.15-5.60 $\mathrm{mm}$ fraction was processed. These chips were placed in a beaker in a fume hood and immersed in $80 \%$ acetic acid with a watch glass on top. Exposure times varied between 7-47 hours and proved much more difficult to judge than the marl samples (refer to Chapter 5). The samples were sieved once the acid started to change colour to slightly yellow, and/or the supernatant became frothy and sediment started to gather in the bottom of the beaker (Figure 4.8). Following acid digestion, the residue was rinsed thoroughly over a $63 \mu \mathrm{m}$ sieve and dried again in the oven. The resulting sample was then boiled in a Calgon solution (sometimes 2-3 times) together with approximately $30 \%$ hydrogen peroxide at $90^{\circ} \mathrm{C}$ on a hotplate for $1-2$ hours. The sample was again rinsed through a $63 \mu \mathrm{m}$ sieve, dried in the oven and put through a $500 \mu \mathrm{m}$ sieve. This resulting fraction was examined under a stereo microscope. If rock matrix was adhering to the foraminiferal tests then the residue was placed in a beaker, immersed in water and treated with ultrasound for 10-60 seconds. The sample was then re-boiled in 
Calgon and peroxide, sieved, re-dried in the oven and put through a microsplitter to obtain the appropriate amount of material for picking foraminifera.

\subsection{Microfossil census and analysis}

The final split of the residue for both lithologies was passed through a $150 \mu \mathrm{m}$ sieve. The 150-500 $\mu \mathrm{m}$ fraction was then weighed, split with a microsplitter and sprinkled onto a tray randomly for an initial survey of 200 tests to determine the planktic/benthic ratio. The surveyed fraction was put back into the sample and the residue re-split until a minimum of 100 planktic foraminifera were obtained. This residue was sprinkled onto a slide and the entire sample was picked and separated into the following categories: Subbotina, Acarinina, Morozovella, and other planktic foraminifera. Numbers of unidentified planktic foraminifera were also logged. The percentage of each foraminifera genus, other planktics and unidentified planktics was calculated in relation to total number of planktic foraminifera. Planktic foraminifera percentages and radiolarian/foraminifera (R/F) microfossil ratios were also formulated.

Thirteen samples (206.829-207.465 m; L3/M/1-L4/M/2) were selected for minimum counts of 300 specimens to provide a more statistically robust analysis across the J CIE (See chapter 5). This included part of the J CIE in which percentages of Morozovella increased and peaked at $28 \%$ (see Chapter 6 ). The purpose of the higher counts was to provide a check on the reliability of counting 100 specimens. These new samples were designated L/3/M1aL/4/M/2a. Previously counted material ( 100 specimens) was included in these revised 300 specimen counts of planktic foraminifera (see Chapter 5).

Comparison of previously processed marls from the same Trial Set with those processed in acid would have been ideal. However, excess processed residue could not be found in the collections and Strong's analysis of foraminifera involved different size fractions, and were therefore not able to be directly compared with this study's census counts (Strong et al., 1995). Strong also noted that in these Lower Marl assemblages, preservation of foraminiferal tests was very poor and therefore distinguishing between Acarinina and 
Subbotina was difficult. Consequently, these two genera were lumped together in foraminiferal population analyses corresponding samples in these previous studies (Strong et al., 1995; Hollis et al., 2005b).

\subsubsection{Absolute Abundance}

Eight thin sections were made from the low-resolution Trial Set. This enabled comparison of absolute abundance of microfossils observed in the thin section slides with absolute abundance calculated from the microfossil assemblages. Both lithologies were sectioned (parallel with bedding where possible) with a rock saw and embedded in Epotek 301 epoxy resin then lapped to within $30 \mu \mathrm{m}$ thickness at the GNS Science Thin Section Laboratory. These sections were examined on a petrological microscope using a point count technique to determine the ratio of matrix vs. microfossils. Only specimens that appeared to be equal or greater to half a microfossil were logged in the counts. Results from 200 points per slide were recorded for each of the lithologies.

Although absolute abundance was calculated from the microfossil populations, the data was not used because analysis showed that the estimates were not a reliable indication of microfossil content when compared to these thin sections of the same samples (see Section 5.4). 


\section{CHAPTER 5: RESULTS - ACETIC ACID-PROCESSING METHOD}

This chapter presents results from the acetic acid leaching method, including analysis of digestion times, foraminifera preservation, additional specimen counts and comparison of thin sections with acid digestion to obtain absolute abundance. A finalised detailed method for acetic acid leaching of limestones is included.

\subsection{Disaggregation in acid}

In a previous biostratigraphic investigation at Mead Stream (Hollis et al., 2005a), some indurated limestones were processed for foraminifera using acetic acid but this was unsuccessful and resulted in no/few identifiable microfossils. In this study, initial experiments on a couple of limestones from the low-resolution Trial Set showed promising results early in the study as demonstrated in Figure 5.1.

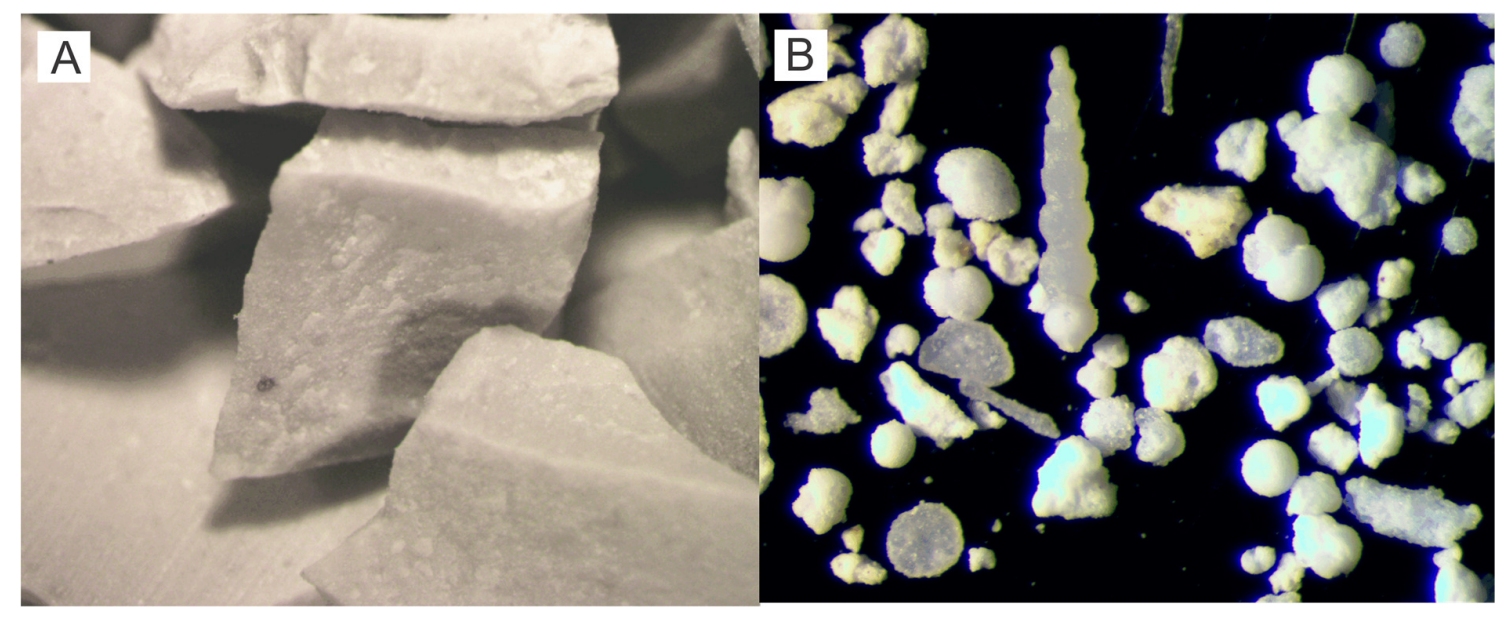

Figure 5.1: Pre-acid limestone chips with microfossils visible in the matrix (A) from $225.80 \mathrm{~m}$ (L24) and the resulting foraminifera and radiolarians (B) after acid treatment in the Trial Set (10 and 40 times magnification respectively). 
Further processing on all 3 sample sets followed, with varied results. Figure 5.2 illustrates a sample from Set $A$ where etching produced another example of clean planktic and benthic foraminifera.

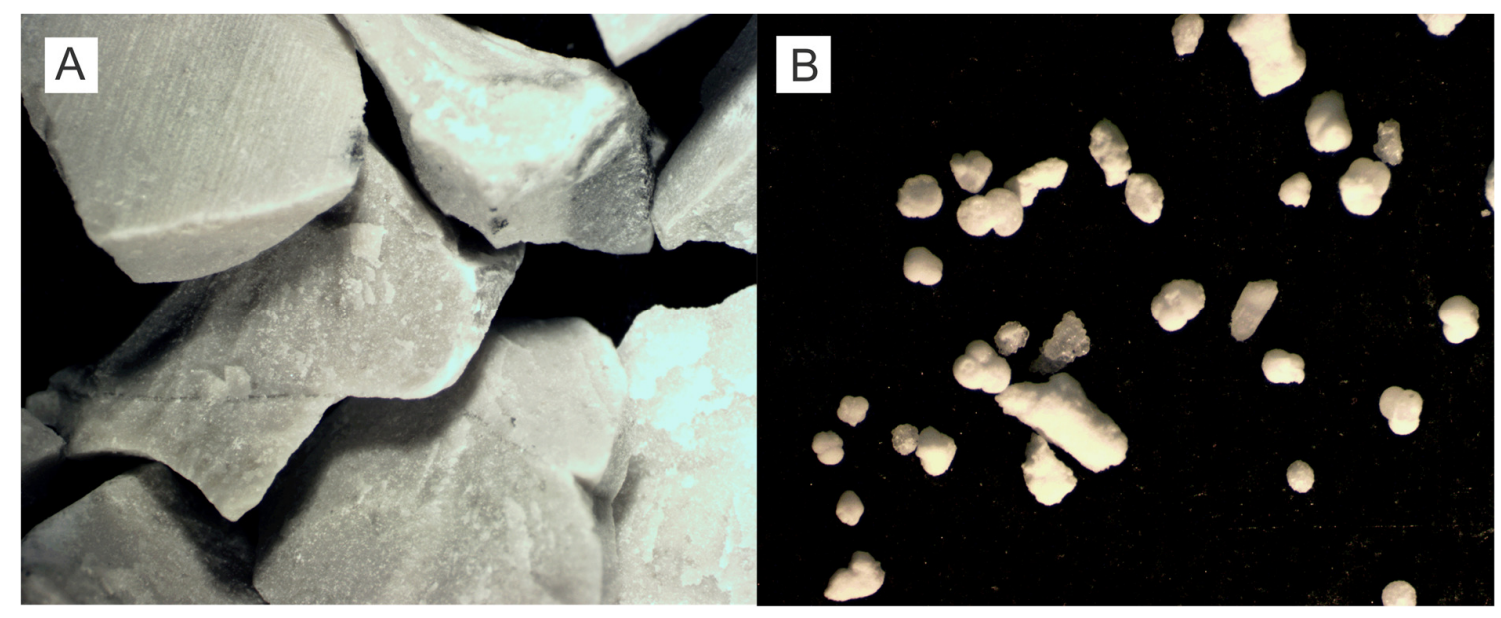

Figure 5.2: Pre-acid limestone chips with microfossils visible in the matrix (A) from 205.485 $\mathrm{m}(\mathrm{L} 3 / 2)$ and the resulting foraminifera and radiolarians (B) after acid treatment in Trial Set (200 and 25 times magnification respectively).

Figure 5.3 shows a photograph of the surface of limestone chips after acetic acid leaching. The image demonstrates how the acid has preferentially dissolved the limestone matrix rather than the fossils, which are intact and close to being released into the supernatant during disaggregation.

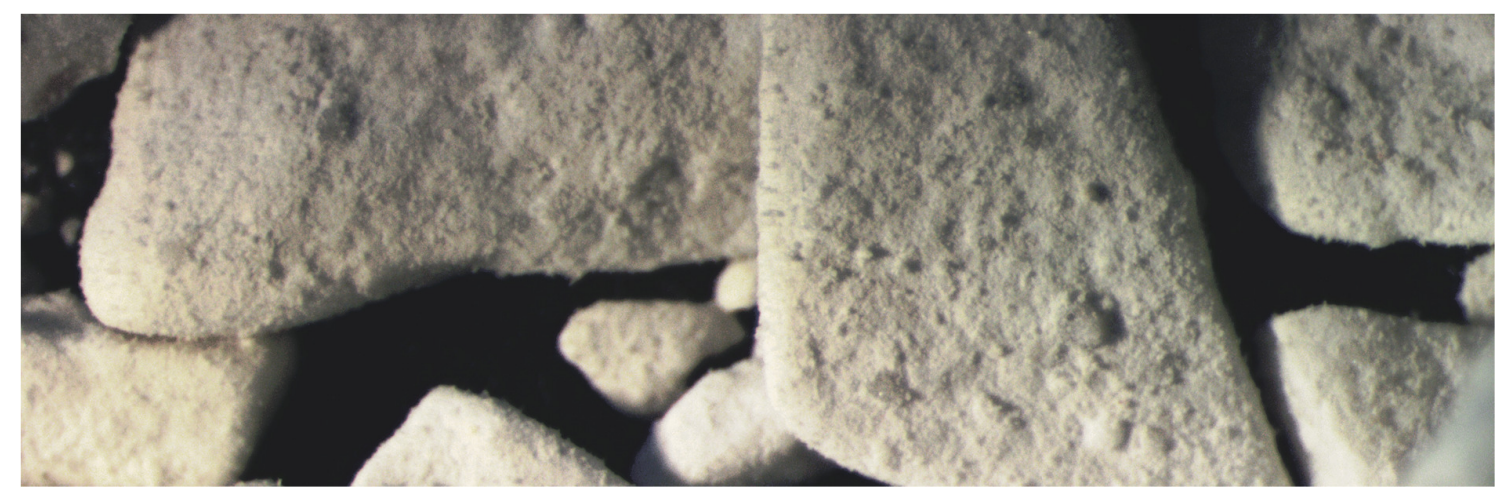

Figure 5.3: Photograph of $225.80 \mathrm{~m}$ (L24) limestone chips after acid leaching showing microfossil protruding from the surface (10 times magnification). 


\subsubsection{Digestion times}

The time taken for marls and limestones to disaggregate differed not only between the two lithologies but also within beds (Table 5.1). Samples from individual beds (in Trial Set) or sub-beds (in Sets A and B) required significantly different durations of glacial acetic treatment to break down the matrix and release the microfossils. This proved to be challenging with unpredictable results even if bedding lithology was used was used to predict reaction time. Most limestone samples were treated multiple times until enough identifiable microfossils were extracted. Table 5.1 illustrates the time taken for samples to be disaggregated in the $80 \%$ acetic acid solution. Exposure times for marls ranged from 4 to 12 hours, while limestones had a wider range of exposure time, from 7 to 47 hours.

Problems arose in an uncontrolled laboratory environment when temperatures dropped during the winter months (because $80 \%$ acetic acid freezes at $-7^{\circ} \mathrm{C}$ ). Samples from the Trial Set at $218.28 \mathrm{~m}$ (L16), $219.53 \mathrm{~m}$ (L17), $220.82 \mathrm{~m}$ (L19) and $221.95 \mathrm{~m}$ (L20) partially froze in the cool conditions overnight in August 2016. As a result, recorded hours in acid may be overestimated for these four samples due to the slowing of the chemical reaction.

\begin{tabular}{|c|c|c|c|c|c|}
\hline Depth $(\mathbf{m})$ & Sample number & Hours in acid & Depth $(\mathbf{m})$ & $\begin{array}{c}\text { Sample } \\
\text { number }\end{array}$ & $\begin{array}{c}\text { Hours in } \\
\text { acid }\end{array}$ \\
\hline 217.52 & $\mathrm{~L} 15$ & 9 & 206.460 & $\mathrm{~L} 3 / 1$ & 10 \\
\hline 217.84 & $\mathrm{~L} 15 / \mathrm{M}$ & 4 & 206.485 & $\mathrm{~L} 3 / 2$ & 34 \\
\hline 218.28 & $\mathrm{~L} 16$ & 11 & 206.561 & $\mathrm{~L} 3 / 3$ & 34 \\
\hline 218.94 & $\mathrm{~L} 16 / \mathrm{M}$ & 4 & 206.640 & $\mathrm{~L} 3 / 4$ & 34 \\
\hline 219.53 & $\mathrm{~L} 17$ & 11 & 206.699 & $\mathrm{~L} 3 / 5$ & 10 \\
\hline 219.96 & $\mathrm{~L} 17 / \mathrm{M}$ & 4 & 206.766 & $\mathrm{~L} 3 / 6$ & 10 \\
\hline 220.10 & $\mathrm{~L} 18$ & no results & 206.800 & $\mathrm{~L} 3 / 7$ & 12.5 \\
\hline 220.40 & $\mathrm{~L} 18 / \mathrm{M}$ & 7 & 206.829 & $\mathrm{~L} 3 / \mathrm{M} / 1$ & 9 \\
\hline 220.82 & $\mathrm{~L} 19$ & no results & 206.922 & $\mathrm{~L} 3 / \mathrm{M} / 2$ & 9 \\
\hline 221.47 & $\mathrm{~L} 19 / \mathrm{M}$ & 7 & 207.000 & $\mathrm{~L} 4 / 1$ & 10.5 \\
\hline 221.95 & $\mathrm{~L} 20$ & no results & 207.059 & $\mathrm{~L} 4 / 2$ & 13 \\
\hline 222.52 & $\mathrm{~L} 20 / \mathrm{M}$ & 6 & 207.176 & $\mathrm{~L} 4 / 3$ & 13 \\
\hline 222.80 & $\mathrm{~L} 21$ & no results & 207.302 & $\mathrm{~L} 4 / 4$ & 13 \\
\hline 223.60 & $\mathrm{~L} 21 / \mathrm{M}$ & 7 & 207.361 & $\mathrm{~L} 4 / 5$ & 13 \\
\hline 223.78 & $\mathrm{~L} 22$ & no results & 207.400 & $\mathrm{~L} 4 / 6$ & 13 \\
\hline 224.35 & $\mathrm{~L} 22 / \mathrm{M}$ & 7 & 207.428 & $\mathrm{~L} 4 / \mathrm{M} / 1$ & 8 \\
\hline
\end{tabular}




\begin{tabular}{|c|c|c|c|c|c|}
\hline 224.57 & L23 & no results & 207.465 & L4/M/2 & 8 \\
\hline 224.88 & L23/M & 7 & 207.520 & L4/M/3 & 8 \\
\hline 225.80 & L24 & 21 & 207.594 & L4/M/4 & 8 \\
\hline 226.16 & L24/M & 7 & 207.636 & L5/1 & 13 \\
\hline 226.41 & L25 & 21 & 207.682 & $\mathrm{~L} 5 / 2$ & 15 \\
\hline 204.715 & LO/1 & 9 & 207.747 & $\mathrm{~L} 5 / 3$ & 34 \\
\hline 204.765 & LO/2 & 12.5 & 207.849 & L5/4 & 13 \\
\hline 204.845 & LO/3 & 27 & 207.900 & $\mathrm{~L} 5 / 5$ & 11 \\
\hline 204.934 & LO/4 & 20 & 251.573 & L44/1 & 34 \\
\hline 205.085 & LO/5 & 20 & 251.618 & L44/2 & 17 \\
\hline 205.205 & LO/6 & 20 & 251.681 & L44/3 & 39 \\
\hline 205.290 & LO/7 & 10.5 & 251.743 & L44/4 & no results \\
\hline 205.340 & LO/M/1 & 4 & 251.792 & L44/5 & no results \\
\hline 205.400 & LO/M/2 & 4 & 251.900 & L44/6A & 47 \\
\hline 205.486 & $\mathrm{~L} 1 / 1$ & 33 & 251.910 & L44/6B & 30 \\
\hline 205.614 & $\mathrm{~L} 1 / 2$ & 27 & 252.091 & L44/M/1 & 12 \\
\hline 205.689 & $\mathrm{~L} 1 / 3$ & 39 & 252.306 & L45/1 & 29 \\
\hline 205.754 & $\mathrm{~L} 1 / 4$ & 27 & 252.496 & L45/2 & 30 \\
\hline 205.796 & $\mathrm{~L} 1 / 5$ & 19 & 252.565 & $\mathrm{~L} 45 / 3$ & 23 \\
\hline 205.850 & L1/6 & 19 & 252.614 & L45/4 & 23 \\
\hline 205.900 & L1/M/1 & 6 & 252.672 & L45/5 & no results \\
\hline 205.935 & $\mathrm{~L} 1 / \mathrm{M} / 2$ & 6 & 252.780 & L45/6 & no results \\
\hline 205.970 & $\mathrm{~L} 1 / \mathrm{M} / 3$ & 6 & 252.990 & L45/M/1 & 7.5 \\
\hline 206.041 & $\mathrm{~L} 2 / 1$ & 21 & 253.148 & L46/1 & 40.5 \\
\hline 206.084 & $\mathrm{~L} 2 / 2$ & 21 & 253.258 & L46/2 & 26 \\
\hline 206.137 & $\mathrm{~L} 2 / 3$ & 21 & 253.353 & L46/3 & 33 \\
\hline 206.172 & $\mathrm{~L} 2 / 4$ & 27 & 253.426 & L46/4 & 33 \\
\hline 206.201 & $\mathrm{~L} 2 / 5$ & 14 & 253.500 & L46/5 & 40.5 \\
\hline 206.226 & L2/6 & 14 & 254.012 & L46/M/1 & 7.5 \\
\hline 206.265 & $\mathrm{~L} 2 / 7$ & 7 & 254.304 & $\mathrm{~L} 47 / 1$ & no results \\
\hline 206.300 & $\mathrm{~L} 2 / 8$ & 7 & 254.450 & $\mathrm{~L} 47 / 2$ & 22 \\
\hline 206.401 & L2/M & 8 & 254.640 & $L 47 / 3$ & 22 \\
\hline
\end{tabular}

Table 5.1: Digestion times of Mead Stream samples in acetic acid for all 3 sets. Marls are highlighted in blue. Green, purple and orange denote the Trial Set, Set A and Set B respectively. 


\subsection{Preservation of microfossils}

Preservation of microfossils post acid leaching was generally poor to average due to diagenesis and recrystallisation visible on the microfossils under the microscope. Benthic foraminifera, however, were well preserved in comparison to the planktic foraminifera and most ranged from average to well-preserved. Accurate identification of planktic foraminifera proved challenging as the surface ornament of the tests was altered due to recrystallisation and calcite infilling.

Fragments of tests were present in all samples, although the number of fragments varied substantially. Only fossils that had greater than half the test intact were included in the counts. Detail of the fragmentation of foraminifera was not quantified for this study.

To eliminate acid-leaching as the cause of loss of surface ornament, Scanning Electron Microscope (SEM) images of foraminiferal tests were compared for microfossils extracted using standard techniques with those extracted using the acetic acid leaching method. Foraminifera from samples at 218.94 (L16/M) m and $219.96 \mathrm{~m}$ (L17/M) were recorded as poorly preserved after standard washing and sieving using no acid. After acetic acid treatment of the same samples, the improved visibility of diagnostic features of the fossils was noted (compare specimens $A$ and $B$ with $E$ and $F$ in both Figures 5.4 and 5.5).

Samples from limestone beds at 218.28 (L16) and $219.53 \mathrm{~m}$ (L17) which are adjacent marls to the previously examined beds (Figure 4.2) were processed with acetic acid and the foraminifera recovered were of better preservation than those of the marls. Tests had less recrystallisation and greater surface texture was visible (Figure 5.6). Preservation of foraminifera from limestones of sub-beds from both Sets A and B (Figures 5.7 and 5.8 respectively) is poor/average but features allow identification to genus level. The condition of microfossils post acid treatment was poorer in Set B than in Set A specimens due to recrystallisation of calcium carbonate.

Surface features are generally more prominent in the acetic acid leached specimens in most of the microfossils photographed by SEM (Figures 5.4-5.8). Particularly well-preserved specimens include the foraminifera from limestone sample $218.28 \mathrm{~m}$ (L16) shown in Figure 5.6. Despite infilling and recrystallisation of these samples, most of the surface texture is 
visible allowing identification to genus level; the conical pustules of Acarinina are evident (A); the 'honeycomb' cancellate wall structure of the Subbotina is visible (B); and chambers of the two Pseudohastigerina ( $\mathrm{C}$ and F) specimens are clearly defined. Morozovella extracted from limestone samples $205.614 \mathrm{~m}$ (L1/2) and $207.059 \mathrm{~m}$ (L4/2) displays pustules as surface ornament in Figures 5.7 ( $A$ and E). Figures 5.8 ( $A$ and E) from $252.50 \mathrm{~m}$ (L45/2) and $253.43 \mathrm{~m}$ (L46/4) also depict Morozovella specimens with distinct apertures and protruding muricate surface texture. 


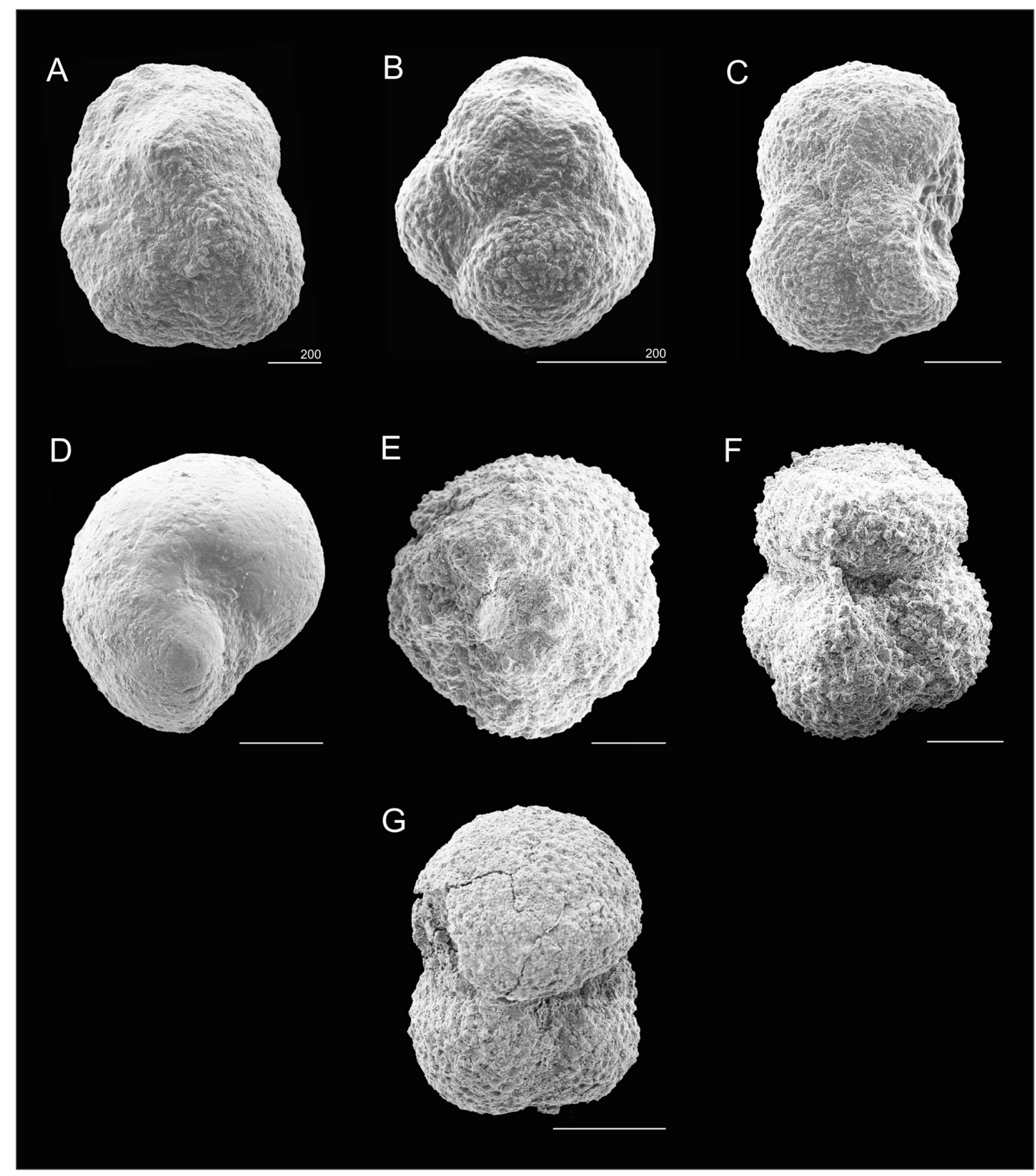

Figure 5.4: Foraminifera from marls in Lower Marl at Mead Stream at 218.94 m (L16/M). AD: Morozovella, Acarinina, Subbotina and benthic Gyroidinoides? specimens processed using standard techniques. E-G: Morozovella, Acarinina, and Subbotina specimens from the same sample processed using the acetic acid-leaching method. Scale bar is $100 \mu \mathrm{m}$ unless stated otherwise. 


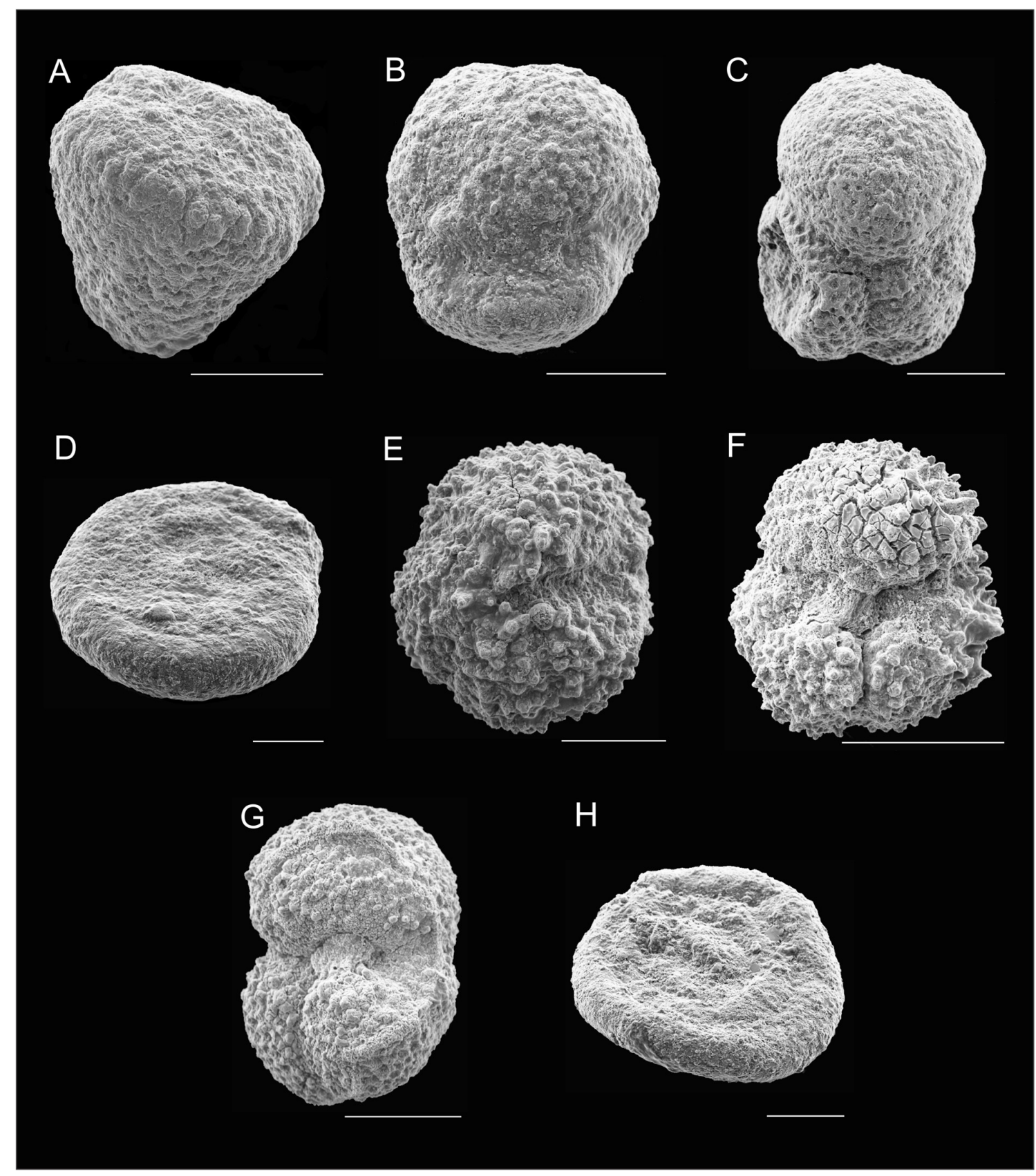

Figure 5.5: Foraminifera from marls in Lower Marl at Mead Stream at $219.96 \mathrm{~m}$ (L17/M). AD: Morozovella, Acarinina, Subbotina and benthic Glomospirella specimens processed using standard techniques. E-H: Morozovella, Acarinina, Subbotina and benthic Glomospirella specimens from the same sample processed using the acetic acid-leaching method. Scale bar is $100 \mu \mathrm{m}$. 


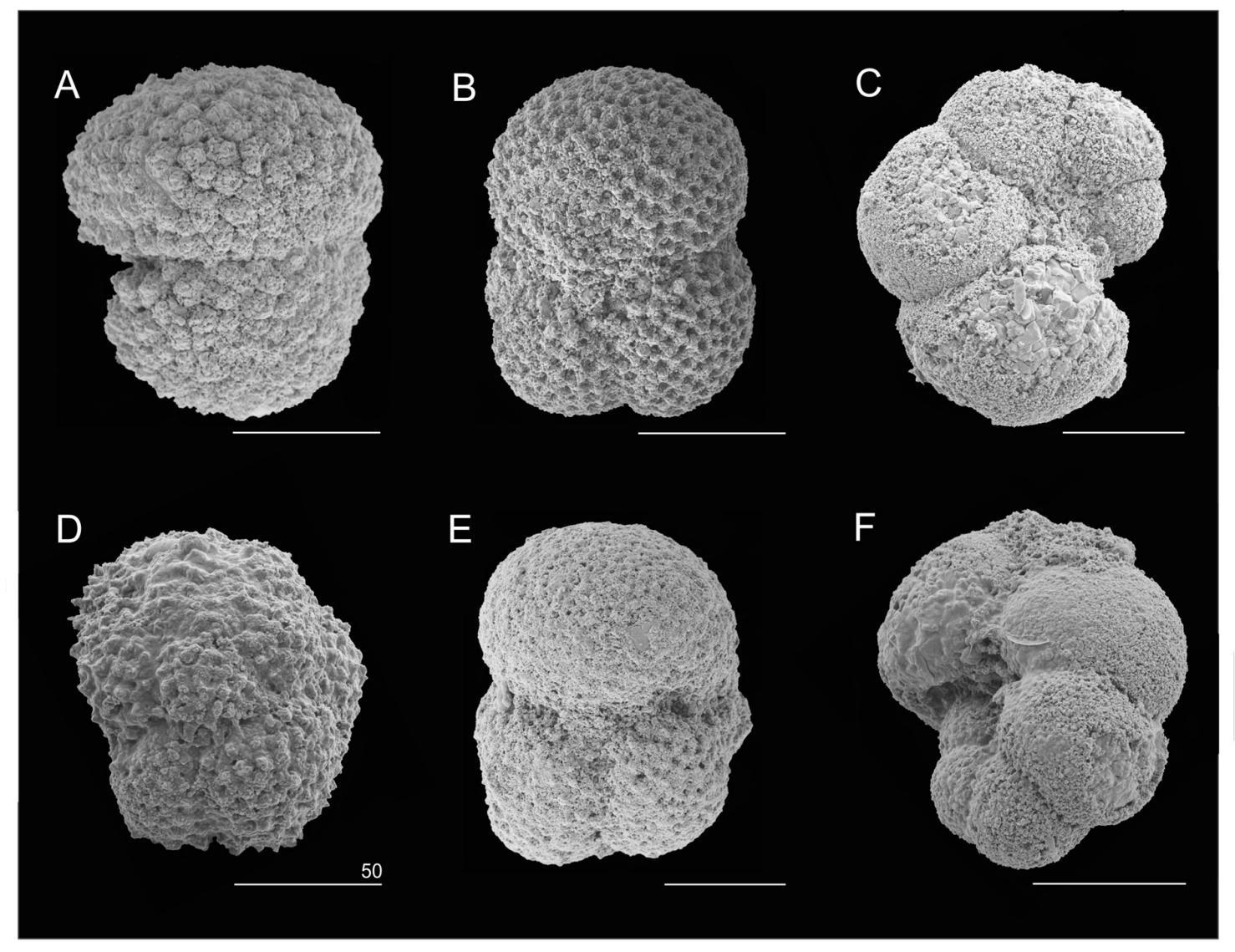

Figure 5.6: Foraminifera from the limestones adjacent to marls featured in the above plates (Figures 5.3 and 5.4). A-C: Acarinina, Subbotina and Pseudohastigerina planktic specimens from 218.28 m (L16) processed using acid-leaching. D-F: Acarinina, Subbotina and Pseudohastigerina planktic specimens from $219.53 \mathrm{~m}$ (L17) processed using the acetic acidleaching method. Scale bar is $100 \mu \mathrm{m}$ unless stated otherwise. 


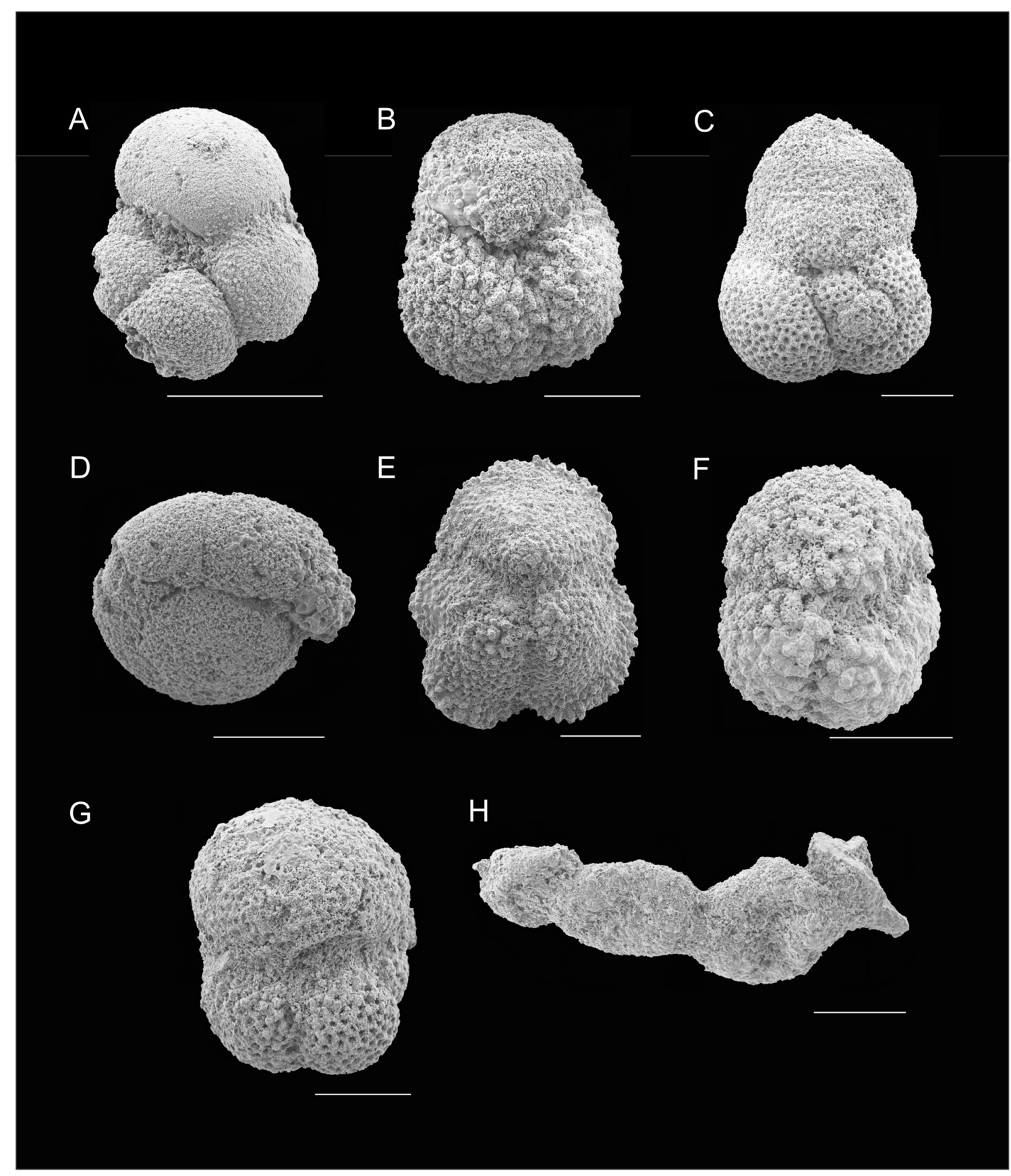

Figure 5.7: Foraminifera from limestones in Lower Marl at Mead Stream - Set A. A-D: Morozovella, Acarinina, Subbotina and Cibicides? planktic specimens from 205.614 m (L1/2) processed using acid-leaching. E-H: Morozovella, Acarinina, Subbotina and benthic Reophax? specimens from 207.059 m (L4/2) processed using the acetic acid-leaching method. Scale bar is $100 \mu \mathrm{m}$. 


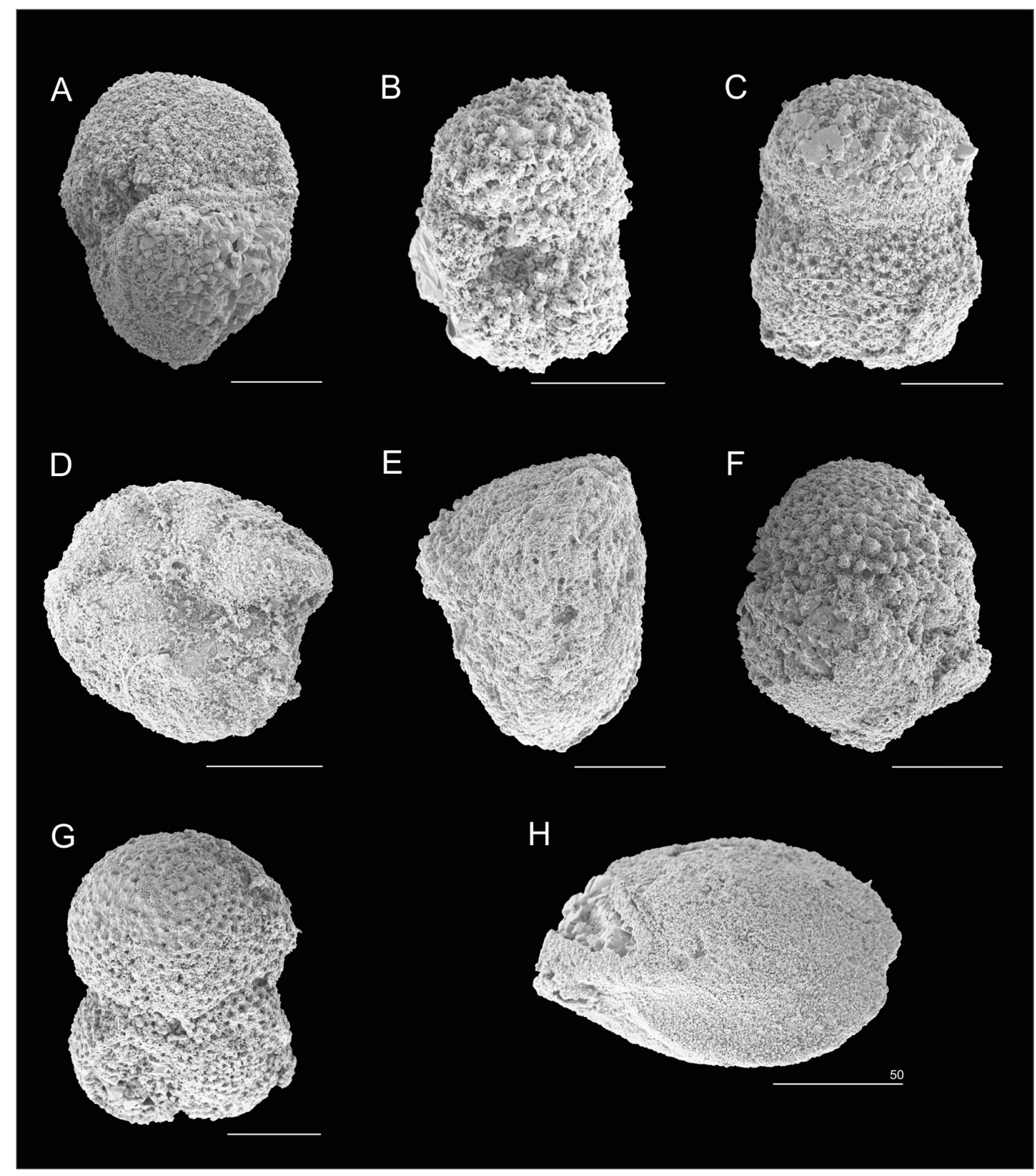

Figure 5.8: Foraminifera from limestones in Lower Marl at Mead Stream - Set B. A-D:

Morozovella, Acarinina, Subbotina and benthic Cibicides? specimens from 252.496 m (L45/2) processed using acid-leaching. E-H: Morozovella, Acarinina, Subbotina and

Ellisopolymorphona? benthic specimens from $253.426 \mathrm{~m}$ (L46/4) processed using the acetic acid-leaching method. Scale bar is $100 \mu \mathrm{m}$ unless stated otherwise. 


\subsection{Increase in specimen counts}

As mentioned in Chapter 4, a census of 100 specimens was undertaken for all samples in this study. To check statistical accuracy, a census of 300 specimens was undertaken for 13 samples from Set A. Results show very good consistency between the two census sizes, as exemplified by the relative abundance of Morozovella (see Figure 5.9).

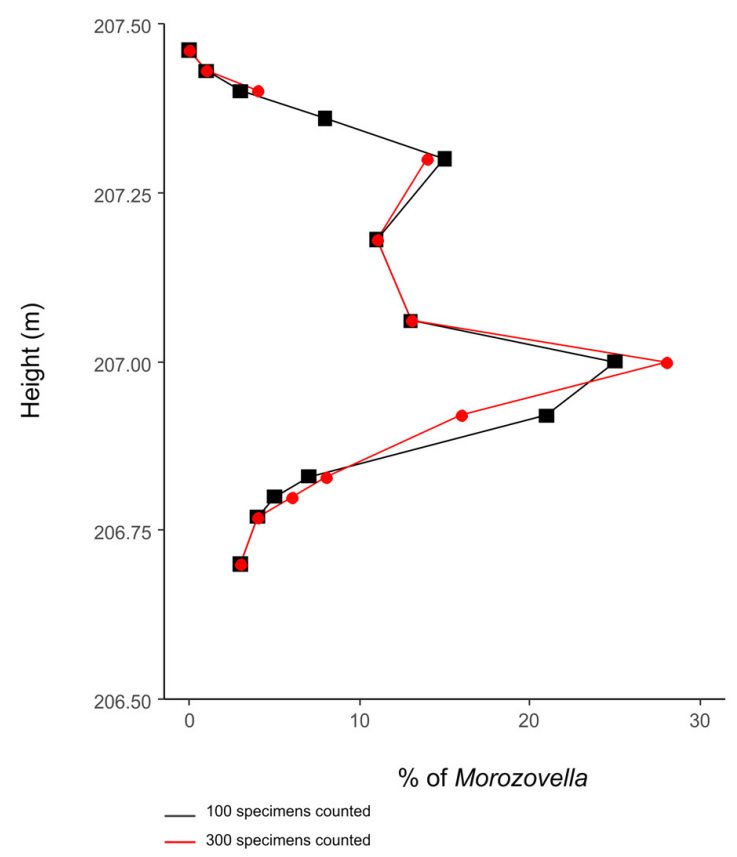

Figure 5.9: Comparison of 100 and 300 specimen census of the 13 samples from $206.699 \mathrm{~m}$ to $207.465 \mathrm{~m}(\mathrm{~L} 3 / 5-\mathrm{L} 4 / \mathrm{M} / 2)$. Note that only 100 specimens could be recovered from sample at $207.361 \mathrm{~m}(\mathrm{~L} 4 / 5)$.

\section{$5.4 \quad$ Thin Sections}

Photography of eight thin section slides spanning the Trial Set (218.28-221.47 m; L16L19/M) was undertaken on a petrological microscope including both marl and limestone samples. Preservation of foraminiferal specimens was moderate to good, with surface ornament and chambers well-defined (Figures 5.10-5.13). Thin sections provided potential for identification of some foraminifera to genus level, but test orientation presented a challenge, therefore thin sections were not used for population census in this study. 


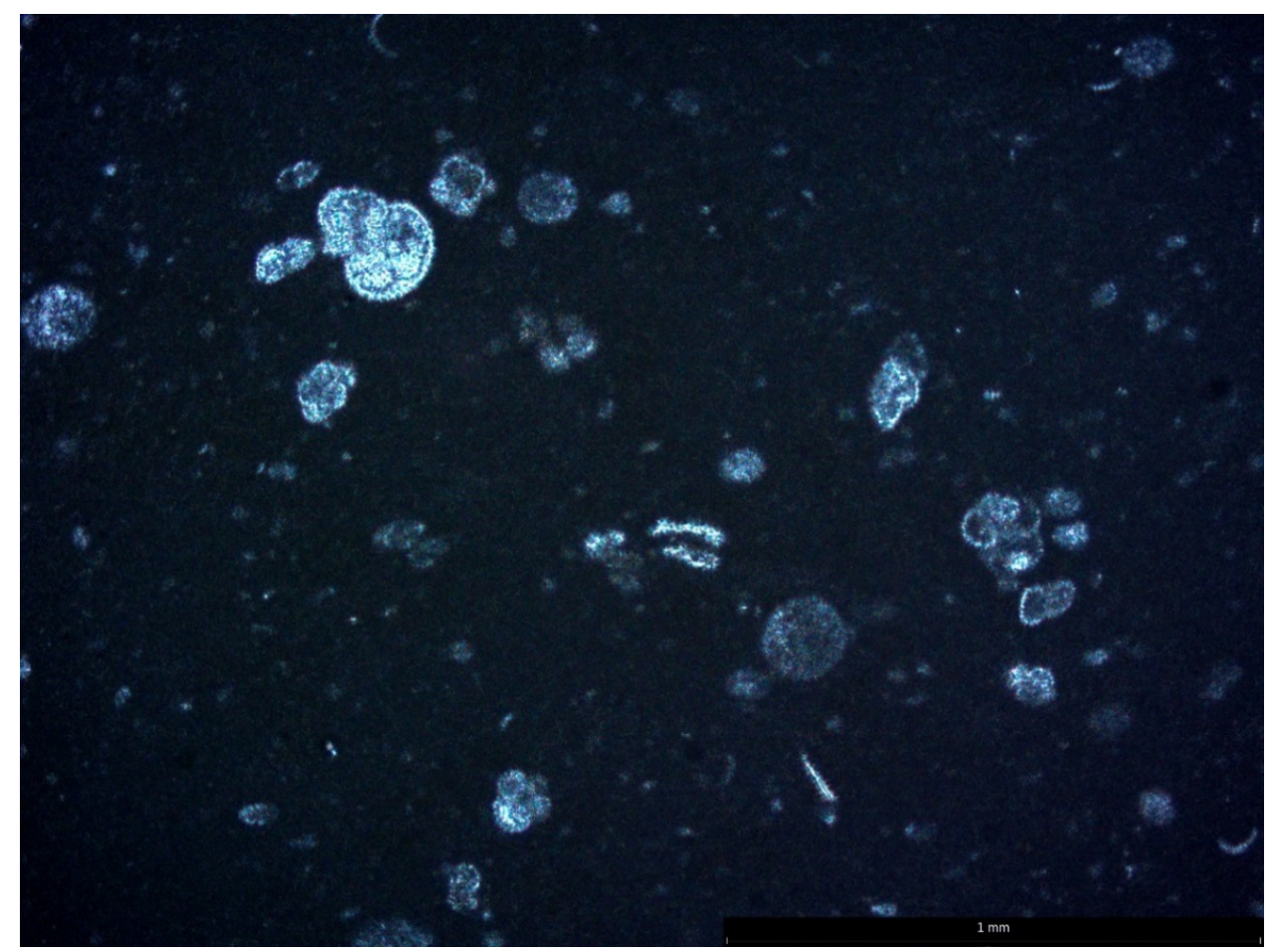

Figure 5.10 Thin Section from 218.28 m (L16) from the Trial Set of Lower Marl, Mead Stream (x 50 magnification).

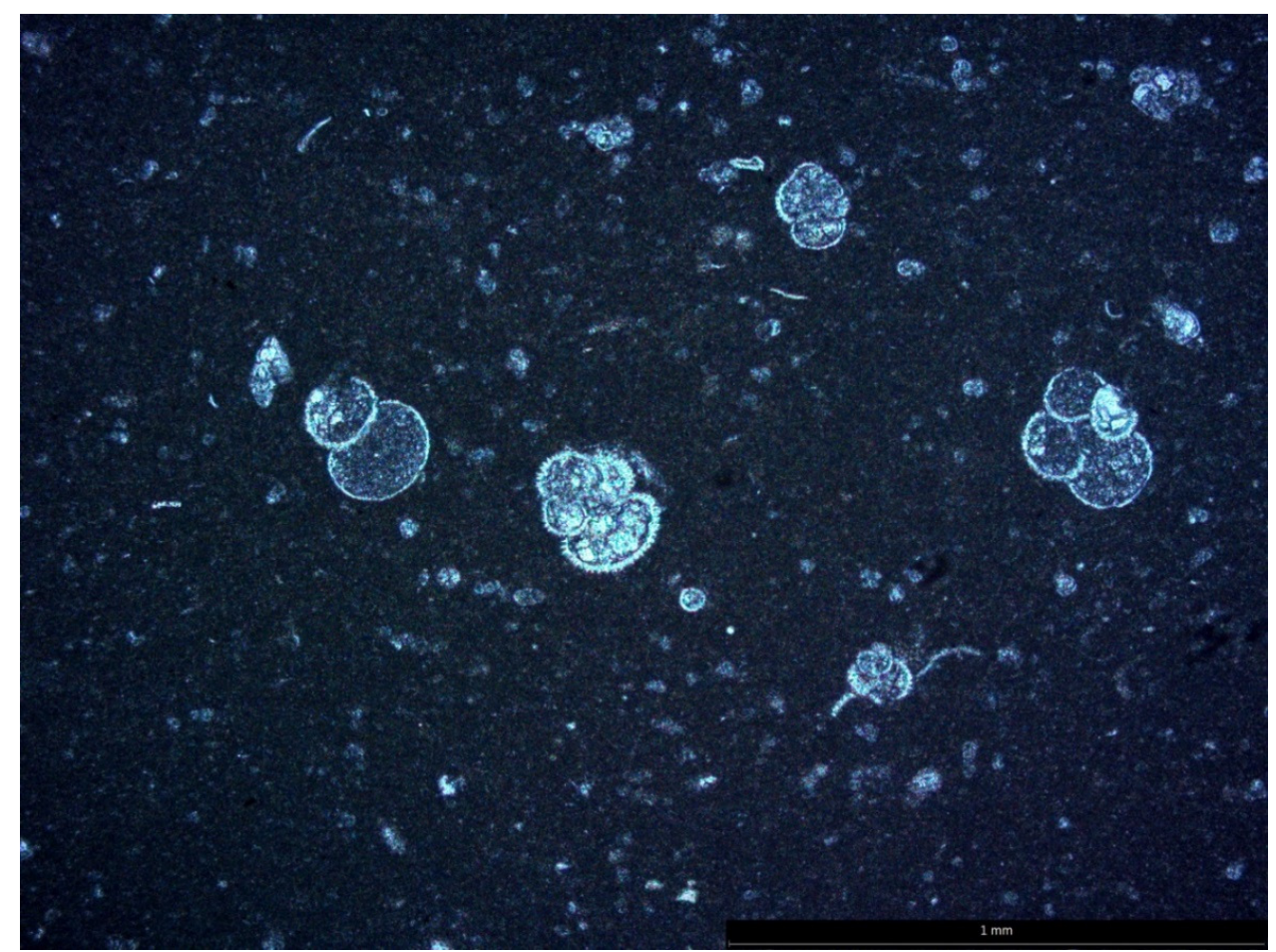

Figure 5.11 Thin Section from 219.53 m (L16/M) from the Trial Set of Lower Marl, Mead Stream (x 50 magnification). 


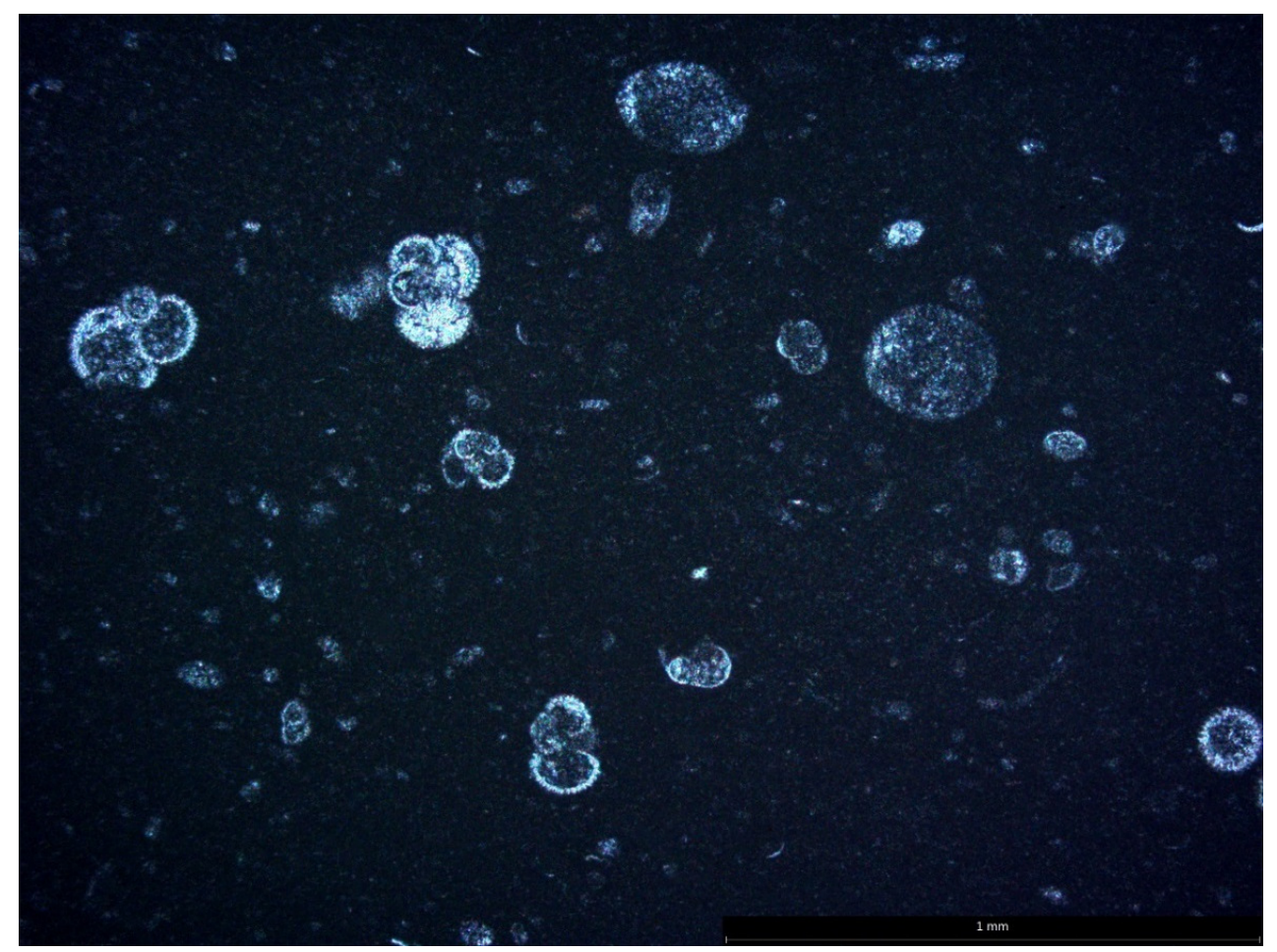

Figure 5.12 Thin Section from 220.53 m (L17) from the Trial Set of Lower Marl, Mead Stream (x 50 magnification).

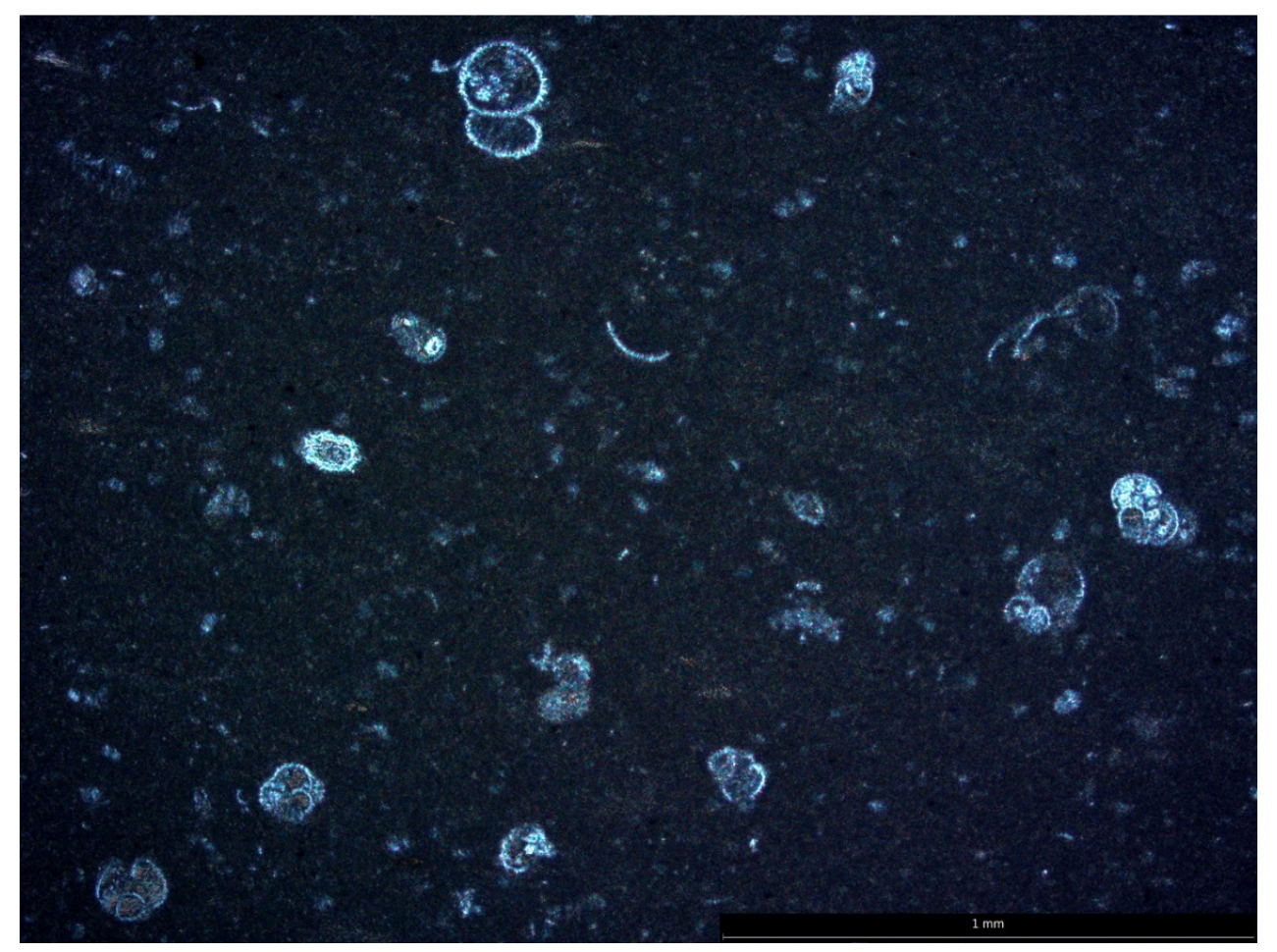

Figure 5.13 Thin Section from $219.96 \mathrm{~m}$ (L17/M) from the Trial Set of Lower Marl, Mead Stream (x 50 magnification). 
Microfossil percentage in the limestone thin sections was marginally higher than in the marls; the four limestones examined ranged from 6.5-9.5\% whilst the four marls contained 1.5-7.5\% lower microfossil content (Table 5.2).

Absolute microfossil abundance for the same samples from the initial Trial Set assemblages (all processed in acid) were calculated using dry weights to compare with the thin section results (Table 5.2). After many attempts at acid leaching substantial intact microfossil tests were not obtained from samples $221.10 \mathrm{~m}$ (L/18) and $220.82 \mathrm{~m} \mathrm{(L/19).} \mathrm{This} \mathrm{is} \mathrm{almost}$ certainly a result of the limestones being highly indurated.

Of these remaining samples, most marls had a very high abundance of microfossils (e.g. at $220.40 \mathrm{~m}(\mathrm{~L} 18 / \mathrm{M})$ ) with one sample containing low numbers of microfossils per gram (at $221.47 \mathrm{~m}$ (L19/M). Thin section results from the same samples showed a minor difference between the two samples in thin section and major differences in microfossil abundance by weight; it appears that thin sections contain more microfossils in limestones, but absolute abundance from acid leached residues suggest the reverse, although more sample should be processed to provide a conclusive result. This implies that using the acetic acid method on indurated limestones may cause disaggregation of many of the microfossils during the acid-leaching process and that marls break up more readily before the acid has time to destroy many of the microfossils.

Subsequently, it was decided that absolute abundances calculated from the microfossil population weights may be misleading and figures are not discussed in subsequent chapters. 


\begin{tabular}{|c|c|c|c|c|}
\hline Height $(\mathbf{m})$ & Sample \# & \multicolumn{2}{|c|}{ Thin Sections } & M/g \\
\hline & & Microfossil \% & Matrix \% & \\
\hline 218.28 & L16 & 6.5 & 93.5 & 248 \\
\hline 218.94 & L16/M & 6 & 94 & 1701 \\
\hline 219.53 & L17 & 9 & 91 & 2531 \\
\hline 219.96 & L17/M & 7 & 93 & 2562 \\
\hline 220.10 & L18 & 9 & 91 & N/A \\
\hline 220.40 & L18/M & 1.5 & 98.5 & 5090 \\
\hline 220.82 & L19 & 9.5 & 90.5 & N/A \\
\hline 221.47 & L19/M & 7.5 & 92.5 & 296 \\
\hline
\end{tabular}

Table 5.2: Microfossil content from eight samples of the Trial Set interval (218.28-221.47 m; L16-L19/M) Lower Marl, Mead Stream. This table compare calculations from thin sections with estimations from microfossil counts (microfossils per gram (M/g).

\subsection{Finalised Acid Leaching Method}

After processing all 96 samples using the acetic acid-leaching technique and examining the digestion times above, it was decided that a multistep approach of repeated leach/sieve/wash cycles was the most effective method to extract sufficient microfossils. This modified method is outlined below and has been used successfully on additional samples since completing the samples for this study:

\section{Method for acetic acid-leaching of indurated limestones or marls}

\section{Materials and equipment required:}

Suitable Personal Protective Equipment (PPE): lab coat, glasses and gloves and a fume-hood to work in

$80 \%$ acetic acid

$600 \mathrm{ml}$ beakers

Ultrasound machine

Low power microscope 
3 and $5 \mathrm{~mm}$ (or similar) sieves with support frame over sink

Waste containers for acid

Distilled and tap water

Small bench-top wash bottles - one with $80 \%$ acetic acid and one with water

\section{STAGE 1: Setup}

1. If necessary remove the weathered surface from the sample on a diamond grinding wheel, rinse clean and dry in the oven at $50-65^{\circ} \mathrm{C}$.

2. Crush into approximately $3-5 \mathrm{~mm}$ chips with a rock hammer

3. Sieve (using a nest of $3 \mathrm{~mm}$ and $5 \mathrm{~mm}$ sieves or similar).

4. Put the $3 \mathrm{~mm}-5 \mathrm{~mm}$ fraction into a clean labelled $250 \mathrm{ml}$ beaker.

5. Record the dry weight of chips.

\section{STAGE 2: Acid-leaching}

6. Add $80 \%$ acetic acid to the sample in a fume hood. Ensure the acid is approximately $2 \mathrm{~cm}$ above the limestone chips. Observe the reaction and leave to digest for a few hours - (depending on lithology and reaction in the acid). If the supernatant is cloudy/frothy and there are grains in the beaker then digestion has taken place and the sample can be sieved. The desired result is to end up with approximately $50 \%$ sediment and $50 \%$ intact chips, however the harder limestones may not produce much sediment and may need multiple washes to collect sufficient microfossils.

\section{STAGE 3: Rinsing and drying}

7. Once this cloudy/frothy liquid is observed, rinse the samples through a $63 \mu \mathrm{m}$ sieve over a waste container in the fume hood.

8. Swirl the beaker gently and tip as much as the frothy liquid into the sieve as possible.

9. Using acetic acid in a small bench-top wash bottles bottle, add excess acid to the rock chips, swirl and tip off the supernatant again - repeat three times in total.

10. Add $80 \%$ acid to the chips in the beaker to begin digestions again and put aside.

11. There should now be a small amount of fine sediment and fossil material in the sieve. 
12. Use generous amounts of water to flush the sieve and rinse the residue several times. It is essential to ensure the acid reaction ceases.

13. Transfer the resulting sediment from the sieve into a beaker using minimal water.

14. Repeat steps 5-12 and continue to collect the sediment into the beaker. Check you have enough microfossils by tipping into a watch glass and examining the wet residue under the microscope. It may be necessary to repeat the procedure 2-5 times.

15. Dry the residue in the oven at $50-65^{\circ} \mathrm{C}$.

16. Tip the waste acid mixture into the appropriate acid disposal system.

\section{STAGE 4: Microscopic examination}

17. Examine the dry residue under the microscope. If the sample does not contain enough identifiable specimens then repeat the steps above.

18. If there are sufficient amounts of material but the fossils are not clean, sieve through a $500 \mu \mathrm{m}$ sieve and expose the $<500 \mu \mathrm{m}$ fraction to $10-60$ seconds of ultrasound. Collect the $>500 \mu \mathrm{m}$ set aside for further processing if necessary. Note: This is not usually necessary for marls or marly limestone samples as they break down easily.

19. When residue is clean, put through a nest of 150 and $500 \mu \mathrm{m}$ sieves and split (using a micro-splitter) and use the $150-500 \mu \mathrm{m}$ fraction for paleontological analysis. 


\section{CHAPTER 6: RESULTS - PALEONTOLOGY}

Assemblages from the initial low-resolution Trial Set spanning 217.54-226.41 m (L15-L25) were useful for gauging times on acid exposure and developing the method, but not for microfossil content because insufficient limestones were processed to enable comparisons with the marl samples. Only 15 of the 21 limestone samples processed from this set yielded enough microfossils for assemblage counts due to the indurated nature of the limestone, despite repeated processing. Therefore, the low-resolution sample suite census data will be referred to only briefly and the main focus of this study are the data sets obtained from the two high resolution sets: Set $A$ and Set $B$. It should be noted that R/F frequencies are a relative guide, due to inability to obtain absolute abundances. Paleontological data is available in Appendix A.

\subsection{Microfossil assemblages}

Identification of planktic foraminifera tests is based on Pearson et al. (2005), Olsson et al. (1999) and Hornibrook et al. (1989). Benthic specimens were classified according to Hornibrook et al. (1989) and Bolli et al. (1994).

Three foraminifera genera are dominant in all three sample suites; Subbotina, Acarinina and Morozovella. For the census study, these three genera were counted separately. The remaining planktic species were simply recorded as "other planktics". An additional category of "indeterminate planktics" was used for planktic species that could not be confidently assigned to these four categories, primarily due to lack of surface ornament. Although the shape and structure of most of these unidentifiable specimens suggested that they were likely to be from the Subbotina or Acarinina generas, a conservative approach has been taken. Plotted paleontological data does not include the indeterminate category. Planktic percentage was a total of all foraminifera and R/F ratio was a total of all microfossils; these counts are shown alongside the census data. 


\subsubsection{Trial set}

15 of the 21 samples from this set were successfully leached for foraminifera. Samples from well? indurated limestones at 220.18 m (L18), 220. 82 m (L19), 221.95 m (L20), 222.80 m (L21), $223.78 \mathrm{~m}$ (L22) and $224.57 \mathrm{~m}$ (L23) did not disaggregate and very low microfossil abundance was detected i.e. less than 30 specimens. Thus, these samples were not included in the census counts. Any average calculations for the Trial Set will contain more data from the marl beds. Table 6.1 presents the relative abundances of all the count categories and includes percentage of planktic foraminifera and the R/F ratio as a separate count.

Of the 15 samples that yielded microfossils, the percentage of planktic foraminifera was high (ranging from 84-98\%). Prior to the K CIE these populations were generally high, peaking at $98 \%$ within the event and decreasing afterwards to lower values than previously.

Recording percentages of $31-74 \%$ with an average of $58 \%$, Acarinina was the most dominant genera in all but 2 samples (limestone samples L18.28 m; L16 and 226.41 m; L25)) in which Subbotina dominated. Acarinina populations consistently increase in the limestones samples and decrease in the marls.

Samples from the Trial Set yielded assemblages containing 14-56\% Subbotina with a mean of $28 \%$. Subbotina numbers were consistently higher in the limestone samples when compared to adjacent marl samples. The absence of sufficient microfossil specimens in the limestones of the Trial Set during the $\mathrm{K} \mathrm{CIE} \mathrm{means} \mathrm{that} \mathrm{it} \mathrm{remains} \mathrm{unknown} \mathrm{as} \mathrm{to} \mathrm{whether}$ this trend was replicated through this event.

Morozovella percentages generally remained at $3 \%$ or below. The only exception was one marl sample following the $\mathrm{K} \mathrm{CIE} \mathrm{(L23/M} \mathrm{at} 224.88 \mathrm{~m}$ ) where Morozovella reached its highest value of $7 \%$.

Fractions of other planktic foraminifera genera fluctuated throughout the samples from $8 \%$ to $21 \%$ and an average of $13 \%$. 
Radiolarian percentages in the Trial Set were all greater than $1 \%$. Values averaged $10 \%$ with lower percentages ( $\leq 4 \%$ ) spanning the $\mathrm{K} \mathrm{CIE}$. A large peak in abundance equivalent to a $\mathrm{R} / \mathrm{F}$ ratio of 1.51 and representing $60 \%$ of the microfossil assemblage occurs in $L 24(225.80 \mathrm{~m})$.

\begin{tabular}{|c|c|c|c|c|c|c|c|c|}
\hline Height $(\mathrm{m})$ & Sample \# & $\%$ Acar & $\%$ Sub & $\%$ Mzv & $\%$ other planktics & Total & $\%$ planktics & F/R ratio \\
\hline 226.41 & L25 & 34 & 46 & 3 & 17 & 100 & 89 & 0.11 \\
\hline 226.16 & L24/M & 68 & 14 & 0 & 18 & 100 & 80 & 0.12 \\
\hline 225.80 & L24 & 38 & 53 & 1 & 8 & 100 & 87 & 1.51 \\
\hline 224.88 & L23/M & 68 & 19 & 7 & 7 & 100 & 84 & 0.02 \\
\hline 224.57 & L23 & - & - & - & - & 100 & - & - \\
\hline 224.35 & L22/M & 61 & 19 & 1 & 19 & 100 & 88 & 0.07 \\
\hline 223.78 & L22 & - & - & - & - & 100 & - & - \\
\hline 223.60 & L21/M & 71 & 16 & 2 & 11 & 100 & 90 & 0.02 \\
\hline 222.80 & L21 & - & - & - & - & 100 & - & - \\
\hline 222.52 & L20/M & 55 & 32 & 3 & 9 & 100 & 94 & 0.04 \\
\hline 221.95 & L20 & - & - & - & - & 100 & - & - \\
\hline 221.47 & L19/M & 58 & 32 & 1 & 9 & 100 & 88 & 0.03 \\
\hline 220.82 & L19 & - & - & - & - & 100 & - & - \\
\hline 220.40 & L18/M & 52 & 26 & 1 & 21 & 100 & 98 & 0.01 \\
\hline 220.10 & L18 & - & - & - & - & 100 & - & - \\
\hline 219.96 & L17/M & 74 & 17 & 2 & 7 & 100 & 93 & 0.03 \\
\hline 219.53 & L17 & 71 & 21 & 0 & 9 & 100 & 95 & 0.11 \\
\hline 218.94 & L16/M & 67 & 19 & 1 & 14 & 100 & 95 & 0.04 \\
\hline 218.28 & L16 & 31 & 56 & 0 & 13 & 100 & 91 & 0.17 \\
\hline 217.84 & L15/M & 67 & 16 & 1 & 16 & 100 & 93 & 0.03 \\
\hline 217.52 & L15 & 52 & 33 & 1 & 13 & 100 & 93 & 0.12 \\
\hline
\end{tabular}

Table 6.1 Microfossil assemblages from low resolution samples spanning 217.52 to 226.41 m (L15-L25) from the Lower Marl at Mead Stream. Samples corresponding to the K CIE (219.96-223.6 m) are highlighted in green. Note that missing figures correspond to limestone samples that did not leach sufficient numbers of microfossils.

\subsubsection{Set A}

All samples in Set A yielded microfossils and enabled counts of 100 planktic foraminifera to be made. Figure 6.1 sets out the relative abundances of all the count categories including percentages of planktic foraminifera and the R/F ratio as a separate count.

The percentage of planktic foraminifera in this set fluctuated between $71-98 \%$ with an average of $86 \%$. Slightly elevated planktic values are present in the in the second two thirds of the J CIE (beds L2 and L3). 
In Set A, Subbotina is the most common genus ranging from $30 \%$ to $81 \%$ with a mean of 59\%. The exception are two limestones samples; $205.689 \mathrm{~m}$ and $206.201 \mathrm{~m}$ (L1/3 and L2/5). In these microfossil assemblages the abundance of Acarinina and Subbotina are equal (Figure 4.1).

The percentage of Subbotina drops just before the J CIE to $41 \%$ at $206.829 \mathrm{~m}(\mathrm{~L} 3 / \mathrm{M} / 1)$ its lowest level in set A). Abundance increases in the initial limestone bed (L3) of the J CIE and then drops again in the succeeding marl bed. In the second two thirds of the JCIE, the population recovers and rapidly increases to elevated levels of $78 \%$ and $77 \%$ at $207.849 \mathrm{~m}$ (L5/4) and $207.900 \mathrm{~m}$ (L5/5) respectively.

Acarinina was the second most dominant genus in Set A ranging and is highly variable ranging from $4 \%$ to $48 \%$ with a mean of $21 \%$. Several consecutive low values are evident in the first limestone bed (L3) within the J CIE. Acarinina subsphaerica and Acarinina coalingensis were identified to species level within bed L2 (at 206.041 m-206.265 m (L2/1L2/7)).

Morozovella was identified in 41 of the 51 samples. While the average value for Set A was low at $4 \%$, counts ranged between 0 and $25 \%$ (Figure 6.1). As the figure illustrates, Morozovella numbers increase rapidly between 206.800 and $207.361 \mathrm{~m} \mathrm{(L3/7} \mathrm{and} \mathrm{L4/5),}$ reaching an acme at 207.000 (L4/1) m when the Morozovella content reaches $25 \%$. This corresponds to middle of the J CIE.

Boundaries for the J CIE are defined by the Carbon isotopic results in Chapter 7. If the increase in values over the J CIE are excluded, abundance remained at very low levels between 0 and 5\%. At the same time as the Morozovella acme the percentage of Acarinina declined in subsequent samples. Associated with the increase in these two genera are low Subbotina numbers followed by a recovery in beds L 4 and L5.

Within the $\mathrm{J} \mathrm{CIE}$, samples from marl beds (L2/M, L3/M and L4/M) display peaks in Acarinina and low Subbotina percentages with the situation reversed in the limestones. This is not replicated in the samples leading up to the J CIE in Set A.

Radiolarian occurrence is generally low (an average of $4 \%$ ) and peaks in samples from the middle sub-beds within the limestones (Figure 6.1). All specimens are identified as 
spumellarians. Percentages are even lower (0-1\%) throughout all marl samples. Peaks of greater than $10 \%$ occur at $205.689 \mathrm{~m}$ (L1/3) and between 206.137-206.172 m (L2/2-L2/4) prior to the $\mathrm{J} \mathrm{CIE}$. Radiolarians from Set A reach their maximum R/F ratio of 0.65 at $(40 \%)$ at $206.561 \mathrm{~m}(\mathrm{~L} 3 / 3)$ at the beginning of the J CIE. 


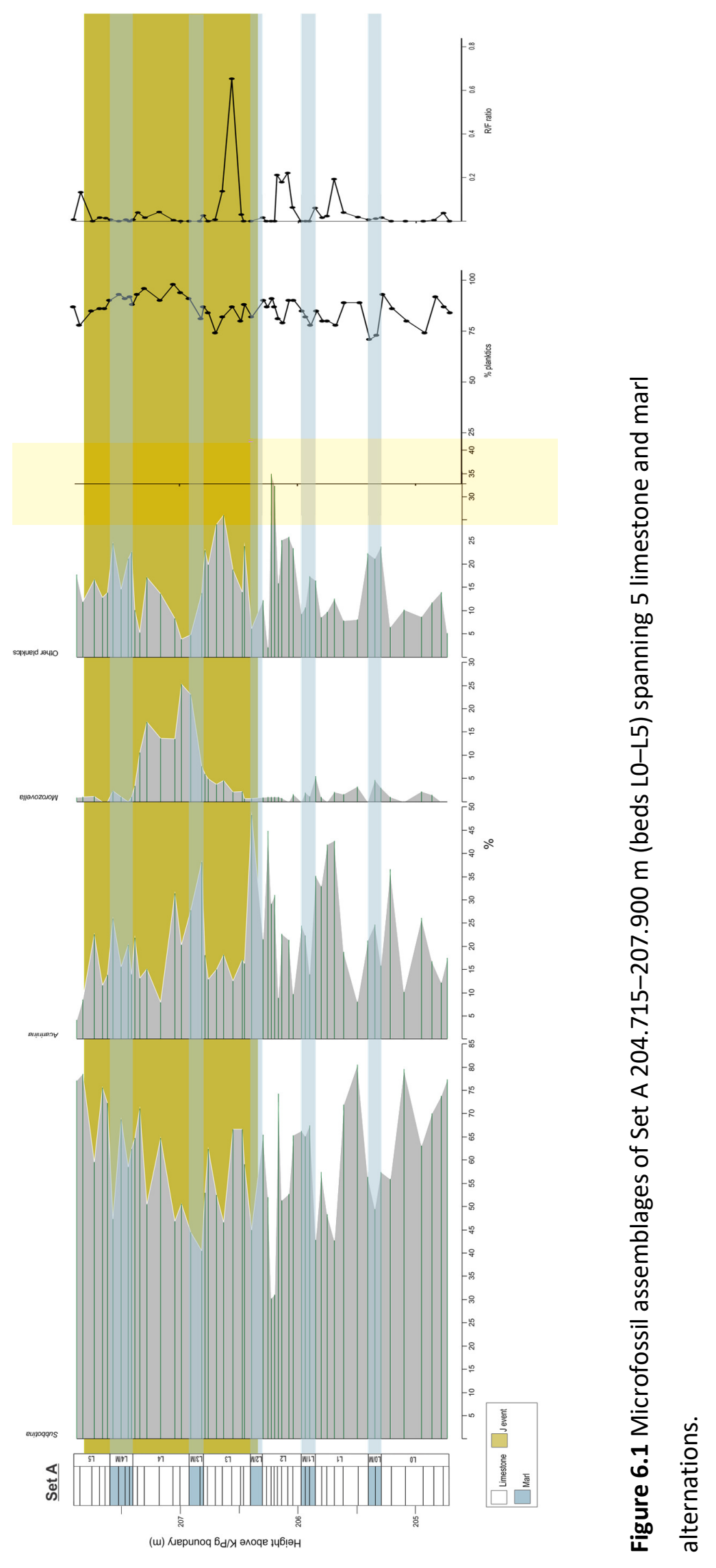




\subsubsection{Set B}

From a total of 24 samples, 19 samples yielded enough identifiable foraminifera to be included in the census counts. Samples at $251.743 \mathrm{~m}$ (L44/4), $251.792 \mathrm{~m}$ )L44/5), $252.672 \mathrm{~m}$ (L45/5), $252.780 \mathrm{~m}(\mathrm{~L} 45 / 6)$ and $254.304 \mathrm{~m}$ (L47/1) yielded counts of under 30 foraminifera per sample despite repeated processing and these have been omitted from any statistical analysis. Of the remaining assemblages, one sample $254.640 \mathrm{~m}$ (L47/3) yielded a total of 89 planktic foraminifera, the remaining samples yielded at least 100 planktic foraminifera. Figure 6.2 sets out the relative abundances of all the count categories including percentages of planktics and the R/F ratio as a separate count.

Planktic percentages ranged from $64 \%$ to $98 \%$ and averaged at $85 \%$. The lowest percentage of planktic foraminifera, although still high, was $64 \%$ and was observed at $252.091 \mathrm{~m}$ (L44/M/1). The benthic population from this sample was examined to investigate paleoenvironmental inferences. The assemblage comprised a diverse fauna from lower-mid bathyal to outer shelf depths. Deep water taxa included Ammodiscus, Bulimina, Nuttallides, Nodosaria, Bolivinopsis and the species Anomalina aotea. The genera Gyroidinoides and Lenticulina were also present.

As in Set A, the most dominant genus was Subbotina, with percentages ranging between 19-73\% with a mean $47 \%$. Abundance shows a significant decline at the Dw-Dm boundary at $254.012 \mathrm{~m}(\mathrm{~L} 46 / \mathrm{M} / 1)$.

Second in terms of abundance, Acarinina ranged from 15 to $70 \%$ with a mean of $44 \%$. Acarinina numbers increase dramatically at the Dw-Dm boundary. Set B generally yielded higher Acarinina percentages and lower Subbotina percentages than Set A. Acarinina subsphaerica was identified to species level at $251.618 \mathrm{~m}$ (L44/2).

Minimum, maximum and mean calculations of Morozovella abundance from Set B are 0\%, $3 \%$ and $26 \%$ respectively, presenting similar values to Set $A$. A substantial increase in Morozovella to $26 \%$ occurs at $252.091 \mathrm{~m}$ (L44/M/1). There are no known global or regional hyperthermal events that correspond to this recorded rise in Morozovella at approximately 52.2 Ma. This is followed by percentages above $6 \%$ until $252.565 \mathrm{~m}(\mathrm{~L} 45 / 3)$. During this acme, Acarinina populations are at their lowest although they recover steadily through in 
the subsequent beds. The percentage of other planktic genera are lower during the Morozovella acme.

Assemblages of foraminifera in Set B do not display consistency in relation to genera and lithology within the three marls. The initial marl corresponding with the Morozovella acme contains Subbotina as the dominant genus, while Acarinina abundance is low. In the latter two marls, there are peaks in abundance of Acarinina corresponding with troughs in percentages of Subbotina within the marls at $252.990 \mathrm{~m}$ (L45/M/1) and $254.012 \mathrm{~m}$ (L46/M/1).

The radiolarian abundances over Set B are generally all over $0 \%$ but do not reach over $10 \%$ until $254.640 \mathrm{~m}$ (L47/3), in which populations peak at $0.24 \mathrm{R} / \mathrm{F}$ (20\%). The (R/F ratio) displays moderate correlation with the planktic percentages and contains exclusively spumellarians. 


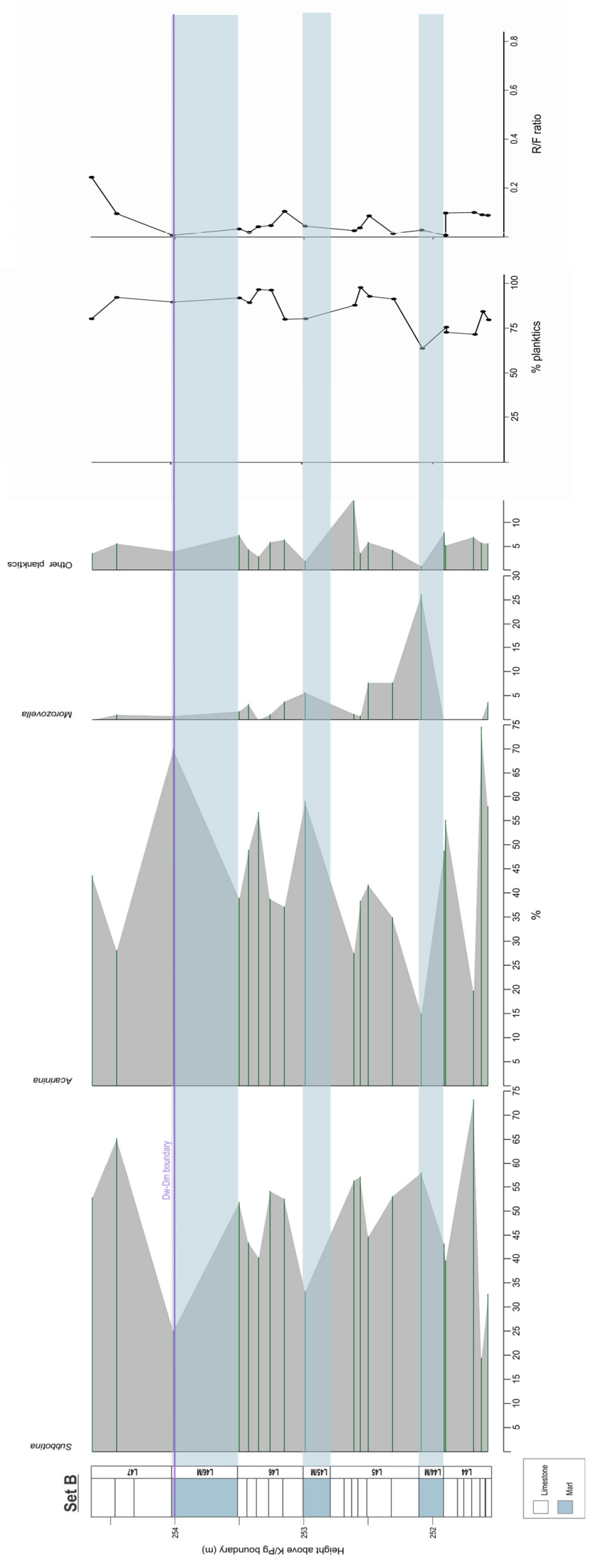

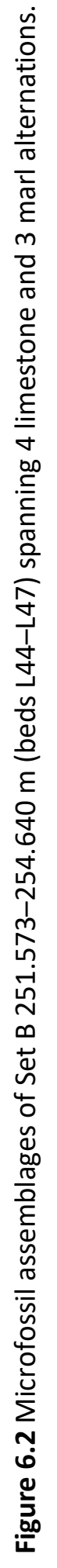




\subsubsection{Trends between Sets A and B}

\section{Foraminifera}

Planktic foraminifera dominated both the high-resolution assemblages with similar average abundance (figures 6.1 and 6.2). Samples for both sets planktic foraminiferal content ranged from $64 \%$ to $98 \%$ with a mean of $86 \%$. All values reflect deposition in an ocean open setting. Peaks in Morozovella for Set A (25\%) and Set B (26\%) are similar. Set B contains higher Acarinina abundance and lower Subbotina abundance than Set A.

\section{Radiolarians}

Radiolarians are higher in Set $B$ as all values are $\geq 1 \%$. In both sets $A$ and $B$, the highest radiolarian abundances occur in the limestones (figures 6.1 and 6.2). 


\section{CHAPTER 7: RESULTS - GEOCHEMISTRY:}

Geochemical analysis for this study consisted of isotopic and XRF analyses (outlined in Chapter 4) of sets A and B. Resulting data is in Appendix B.

\subsection{Carbon isotopic results}

In order to fix the position of the J $\mathrm{CIE}$ and to investigate the possibility of additional similar events being present, the carbon isotope data was measured from sample sets $A$ and $B$ and compared to the $\delta^{13} \mathrm{C}$ Mead Stream record published by Slotnick et al. (2012). This 2012 (Slotnick et al.) data has been corrected to the updated depth measurements from the 2015 Mead Stream log (Crampton, 2015) and plotted against $\delta^{13} \mathrm{C}$ results from this study (Figure 7.1A). The new $\delta^{13} \mathrm{C}$ values generated from sets $A$ and $B$ are in excellent agreement with the 2012 data set.

\section{Set A}

The $\mathrm{J} C \mathrm{CI}$ in set $\mathrm{A}$ is well delineated with $\delta^{13} \mathrm{C}$ values presenting a significant baseline shift to more negative values (Figure 7.1C). A sharp drop in $\delta^{13} \mathrm{C}$ values starting at $206.041 \mathrm{~m}(\mathrm{~L} 2 / 1)$ indicates the beginning of the J event. With the body of the CIE there are 3 distinct drops in value marked by arrows on fig 7.1B. The event terminates with a steep rise in $\delta^{13} \mathrm{C}$ values at $207.849 \mathrm{~m}(\mathrm{~L} 5 / 4) \delta^{13} \mathrm{C}$ before increasing steadily throughout beds $\mathrm{L} / 4 / \mathrm{M}$ and $\mathrm{L} 5$. Set $A$ has an average $\delta^{13} \mathrm{C}$ of $1.07 \%$.

\section{Set B}

In Set $\mathrm{B}, \delta^{13} \mathrm{C}$ also shows a decreasing trend in values (Figure 7.1B) dropping by $1.38 \%$ o between $251.910 \mathrm{~m}$ (L44/6B) to $1.26 \%$ at $252.091 \mathrm{~m}(\mathrm{~L} 44 / \mathrm{M} / 1)$. $\delta^{13} \mathrm{C}$ continues to decline until $254.304 \mathrm{~m}$ (L47/1) before rising again. The high-resolution data from this study shows the lowest $\delta^{13} \mathrm{C}$ value occurring at the Dw-Dm boundary, whereas $\delta^{13} \mathrm{C}$ values from Slotnick et al. (2012) decrease gradually then stabilise across the Dw-Dm boundary. Set B $\delta^{13} C$ values are higher than Set $A$, with a mean of $1.25 \%$. 


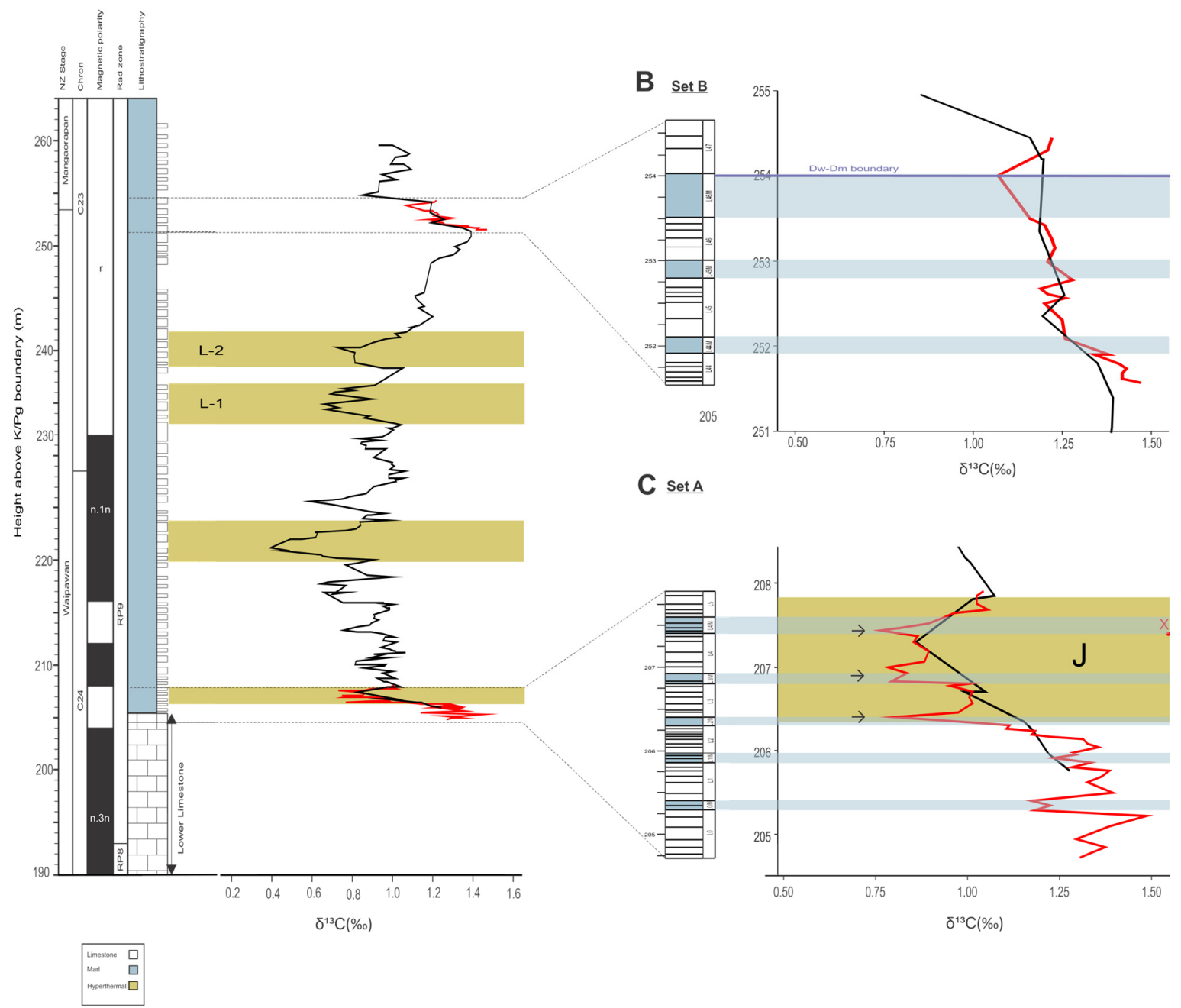

Figure 7.1 Carbon isotope results at Mead Stream spanning 205-260m. Slotnick et al's (2012) data are shown in black. Data from sample sets Set A and B in this study are shown in red. Green shading represents the multiple Hyperthermals. The data point labelled ' $X$ ' at $207.400 \mathrm{~m}(\mathrm{~L} / \mathrm{6})$ from Set $\mathrm{A}$ is an anomalous value of $1.54 \%$ and assumed to be erroneous. 


\subsection{XRF}

XRF analysis was undertaken on samples from Set $A$ and Set $B$ to estimate terrestrial (TRG), excess silica ( $\mathrm{Si}[\mathrm{ex}])$, and carbonate content $\left(\mathrm{CaCO}_{3}\right)$. Measurements of Silica (Si), Calcium (Ca), Iron (Fe) and Aluminium (Al) were recorded among other elements to estimate these fractions. Refer to Chapter 4 for a description of the calculations.

\section{Geochemistry and lithology}

Because excess silica and calcium carbonate can indicate productivity levels and terrigenous material infers input from the continental shelf, geochemical data can assist with paleoenvironmental and paleoclimatic interpretation of the marl-limestone alternations. $\mathrm{Si}[\mathrm{ex}]$, and $\mathrm{CaCO}_{3}$ and TRG were plotted as percentages to compare elemental geochemistry of the marls and limestones within Sets A and B (Figure 7.2):

\section{\% TRG}

TRG rose dramatically within the marl samples, ranging from $18-47 \%$, in comparison to levels of $2 \%-17 \%$ in the limestones. Estimated terrigenous content from Set A values spanned 3-39\% with a mean of $11 \%$ compared to Set $B$ values of $9-47 \%$ with an average of $9 \%$.

\section{$\% \mathrm{CaCO}_{3}$}

$\mathrm{CaCO}_{3}$ was the dominant fraction across both sample sets, predictably presenting higher values in the limestones (70-89\%) in comparison to the marls (50-72\%). Set A contained comparable levels of $\mathrm{CaCO}_{3}$ to Set B; $53-88 \%$ with a mean of $77 \%$ in Set A versus $50-88 \%$ averaging $76 \%$ in Set B.

\section{$\% \mathrm{Si}[\mathrm{ex}]$}

Limestones comprise 7- 19\% Si[ex] and marls contained slightly lower percentages at 2\%15\%. Higher values were consistently observed in the limestones. Excess silica content was slightly higher in Set B; Set A values range from 6\%-18\% with a mean of $12 \%$ and Set B data presents $2 \%-19 \%$ Si[ex] averaging at $14 \%$. 


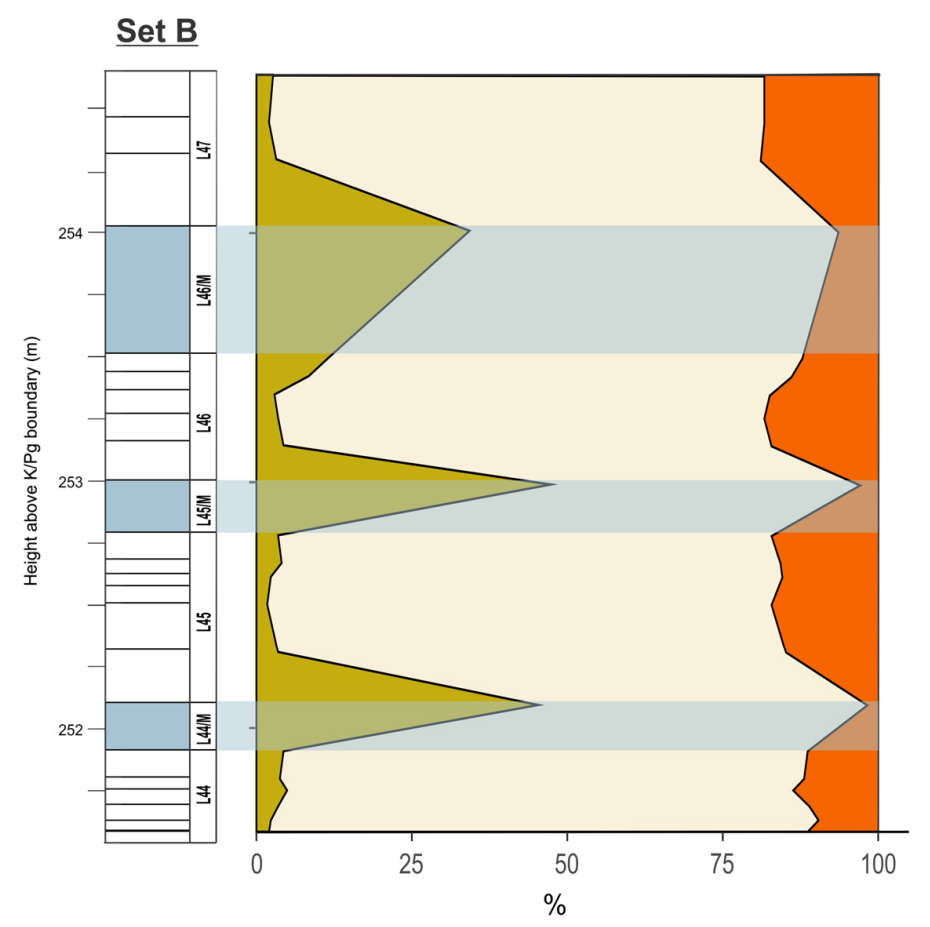

Set A

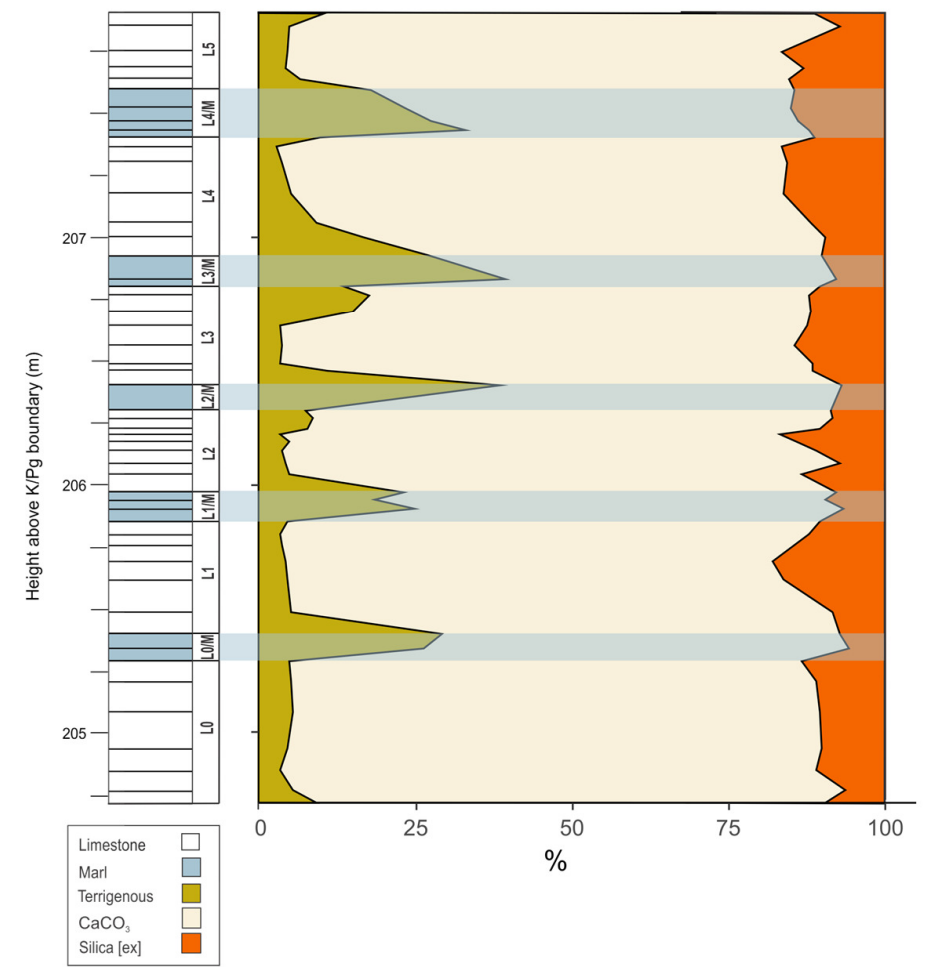

Figure 7.2: Lithological bandygrams showing fractions of terrigenous, $\mathrm{CaCO}_{3}$ and $\mathrm{Si}[\mathrm{ex}]$ across Sets $A$ and $B$. 
Both $\mathrm{Si}[\mathrm{ex}]$ and $\mathrm{CaCO}_{3}$ percentages peak in the central sub-beds of the limestone beds indicating a likely increase in productivity. To examine this further, $\mathrm{CaCO}_{3}$ was plotted against Si[ex]. The resulting plot (Figure 7.3A) shows that there was a positive, albeit weak relationship between both sets and excess silica content with an $R^{2}$ value of 0.1 . When examining correlation of the two sets separately, Set B had a higher value of 0.4 indicating a moderate positive association between $\mathrm{CaCO}_{3}$ and $\mathrm{Si}[\mathrm{ex}]$, whereas Set $\mathrm{A}$ showed no correlation $\left(R^{2}\right.$ value was $\left.<0.01\right)$.

This rise in Si[ex] roughly corresponds to highs in radiolarian abundance observed in limestone assemblages (Figures 6.1 and 6.2) indicating a possible explanation for the increase in biogenic silica. R/F ratios for both sets were plotted against both Si[ex] to examine a correlation that may indicate a link to productivity (Figure 7.3B). No association between the two was observed $\left(R^{2}\right.$ value was $<0.01$ and is therefore not shown on the graph).
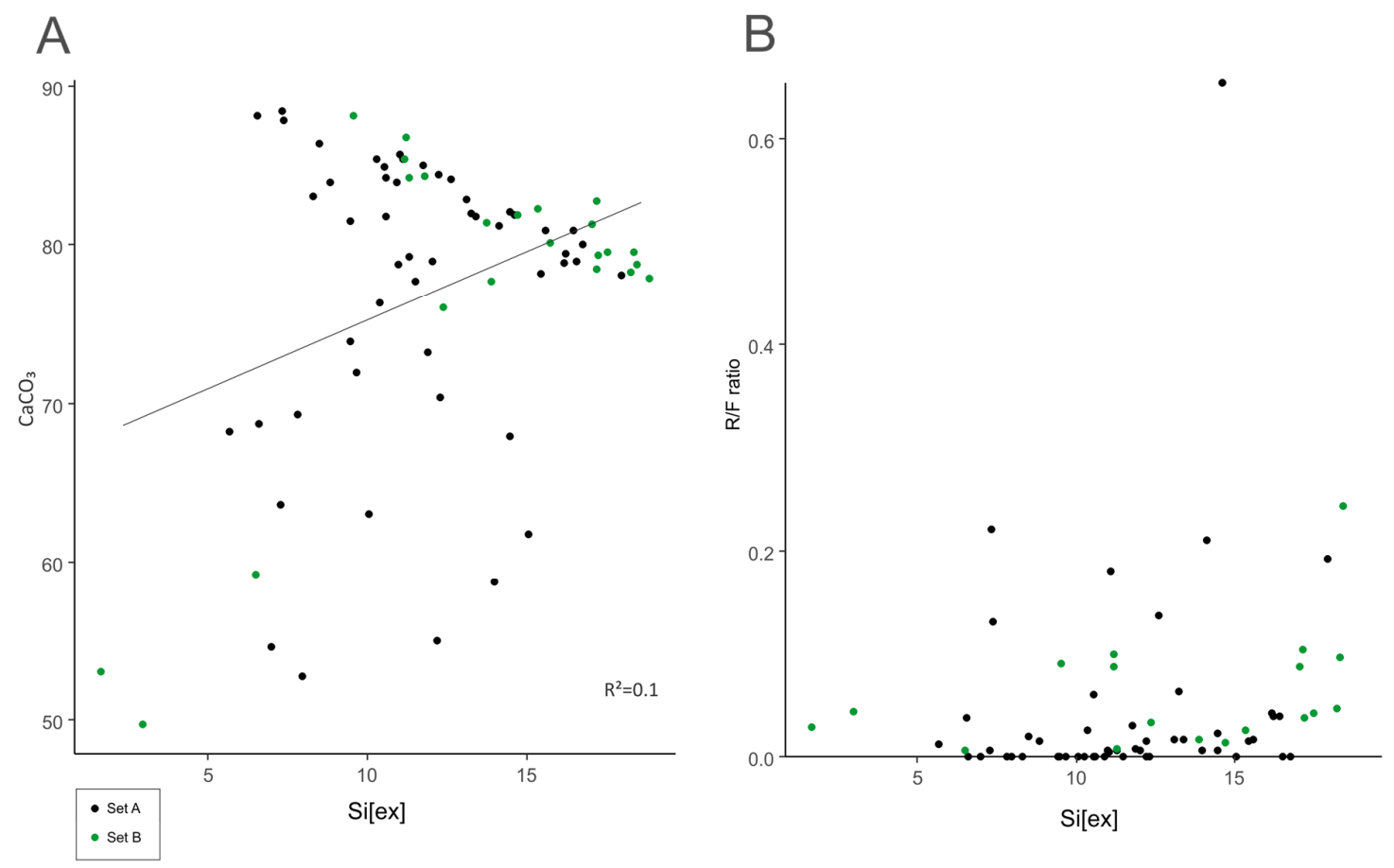

Figure 7.3: Plots of excess silica versus calcium carbonate content $(A)$ and radiolarian abundance (R/F ratio; $B)$. 


\section{XRF and methodology:}

Results (Section 5.1.1) indicate that marl samples required only a few hours exposure in acid to release microfossils as opposed to the limestones which varied widely in disaggregation time. Therefore TRG, $\mathrm{CaCO}_{3}$ and $\mathrm{Si}[\mathrm{ex}]$ were plotted against the reaction time to understand how distinct the two lithologies are in relation to:

1. How long they take to break down in acid and release microfossils and whether XRF data can provide a guide to future processing and;

2. if percentages of $\mathrm{TRG}_{2} \mathrm{CaCO}_{3}$ and $\mathrm{Si}$ [ex]) reflect the lithology designated in the field The plotted data (Figure 7.3) illustrates ample variation in reaction time for limestones to break down, spanning 7 to 39 hours in contrast to marls which disaggregated in 4-12 hours. The overlap in reaction times between the two lithologies exists between 7 to 12 hours and is designated a shaded area on all 3 graphs, where 19 samples are positioned.

\section{TRG}

Graph 7.4A displays the reaction time plotted vs terrigenous content for both Sets, separated out by lithology. A moderate negative relationship $\left(R^{2}=0.48\right)$ occurs indicating that the higher the TRG percentage, the lower the reaction time necessary to leach fossils from the matrix. As to be expected, the softer marls, which have a higher TRG fraction than the limestones, needed less time in acid.

The lithologies appear to be separated by TRG. Limestones and marls form two distinct groups according to their TRG with almost no overlap (Figure 7.4A). Two samples at $206.766 \mathrm{~m}$ (L3/6), $207.594 \mathrm{~m}$ (L4/M/4) yielded similar levels of TRG (17.37 \% and $17.65 \%$ respectively (circled on Figure 7.4A) However when these samples were collected the were identified as different lithologies. A definition of the marls in sets $A$ and $B$ are samples with $17.65 \%$ or greater TRG. 


\section{$\mathrm{CaCO}_{3}$}

Figure 7.4B illustrates a modest positive relationship between $\mathrm{CaCO}_{3}$ and reaction time $\left(\mathrm{R}^{2}=\right.$ $0.36)$ i.e. limestones, which contain higher proportions of $\mathrm{CaCO}_{3}$, took longer than marls to disaggregate. Once carbonate content rose above approximately $80 \%$ (which included most of the limestones) reaction times varied immensely.

Similar to \% TRG in Diagram A, the limestones and marls appear as discrete sets in regard to $\mathrm{CaCO}_{3}$ content with the exception of the two overlapping samples at $206.766(\mathrm{~L} 3 / 6)$ These samples contained $70.34 \% \mathrm{CaCO}_{3}$ and at 205.935 (L1/M/2) 71.88 \% (circled in Figure 7.4B). Otherwise $\mathrm{CaCO}_{3}$ estimations from XRF analyses in this study are useful for identifying limestones as generally containing $\geq 70.34 \%$ calcium carbonate.

\section{Si[ex]}

Comparing Si[ex] content of both lithologies with reaction time in figure 7.4C, a weak positive relationship $\left(R^{2}=0.24\right)$ is apparent between the two. Similar to carbonate, once $\mathrm{Si}[\mathrm{ex}]$ reaches values of about $10 \%$, reaction times vary greatly.

Limestones and marls have a large overlap in silica content which consists of 50 samples (circled on Figure 7.4C) and silica content data is not useful in distinguishing between lithologies. 


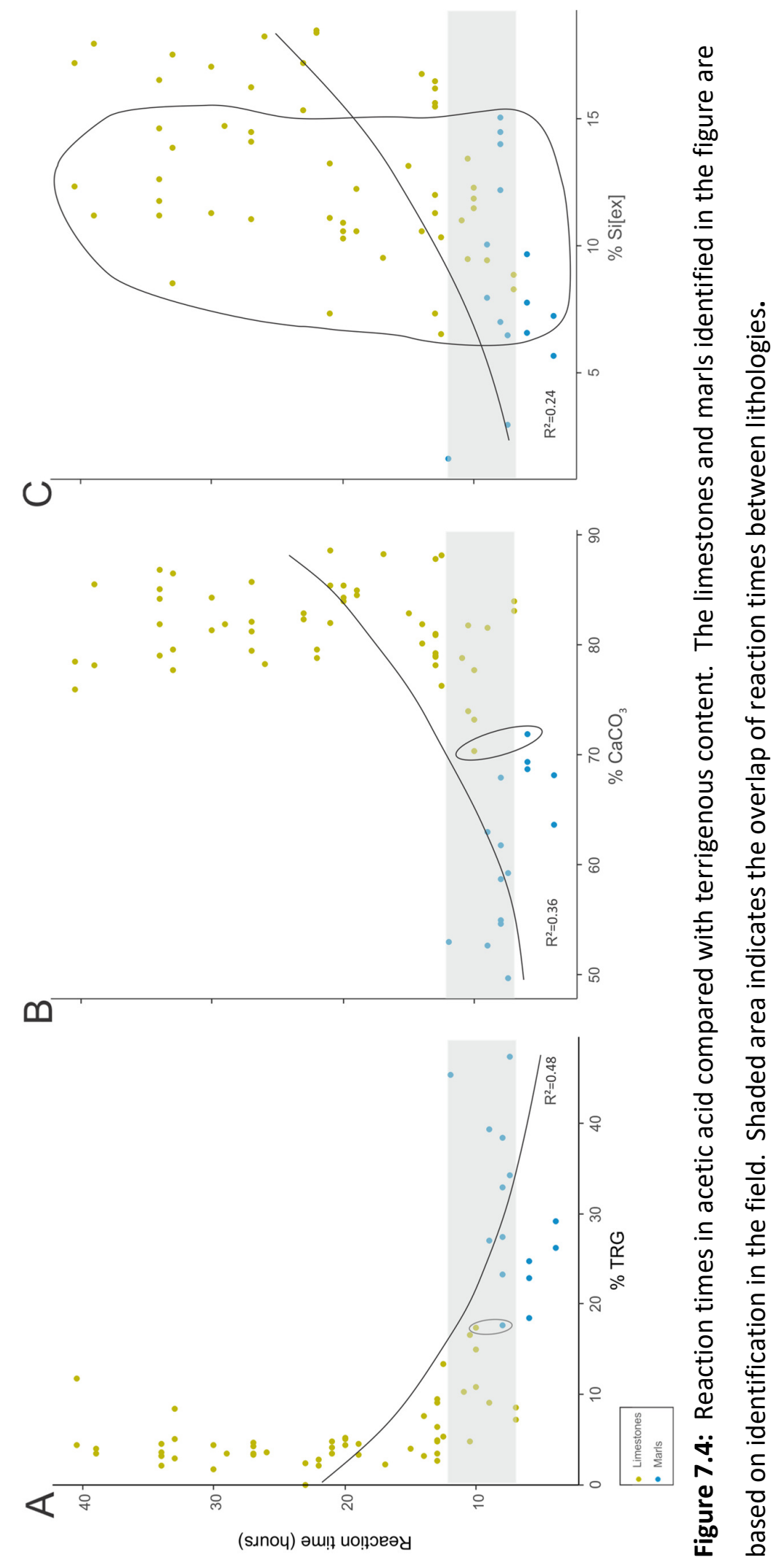




\section{CHAPTER 8: DISCUSSION}

\subsection{Methodology}

\section{Acetic acid leaching}

In this study the acetic acid leaching has proven to be valuable in extracting identifiable microfossils from 85 of the total 96 limestones and marls from Mead Stream. A refined acetic acid leach/sieve/wash cycle was repeated to ensure maximum microfossil yield on samples collected from the Lower Marl (Section 5.6). In summary, foraminifer tests were better preserved after acetic acid treatment compared to standard washing procedures.

Nevertheless, due to diagenetic effects the preservation of foraminifera obtained was poor to average, and recrystallisation of tests is evident in SEM imagery (Figures 5.4-5.8). As a result, microfossils are likely to be underrepresented, particularly in the limestones. Also influencing microfossil abundance is terrigenous dilution: elevated shelf-slope transportation of terrestrial material during deposition in the marls (Figure 7.2) may have diluted microfossil abundance in the marls. Furthermore, after acetic acid processing limestones showed much higher dissolution of microfossils than in the marl samples.

When XRF data was summarised and compared to reaction times, it became apparent that acid exposure may be dependent on biogenic silica and calcium carbonate content (Figure 7.3) although the association was calculated to be a weak positive one. Because estimating acid digestion finishing times of the limestone samples was challenging and likely to be inexact, it may be that the correlation between biogenic silica or calcium carbonate content and processing hours is stronger than the data from this study demonstrates. Reword this in more formal language With future processing, if XRF results are available in advance, they may prove useful for rough estimations of reaction time in similarly indurated limestones.

\section{Advantages of high resolution sampling}

XRF results indicate that while samples from limestones and marls only overlap in TRG and $\mathrm{CaCO}_{3}$ values (Figure 7.4) for a couple of samples, some have comparable percentages. This implies that whilst only two lithologies (limestone and marl) were identified in the field, 
there may be an intermediate category i.e. 'marly limestones' which has been identified in previous studies (e.g. Slotnick et al., 2012). In summary, although the beds have weathered to have the appearance of a sharp contact (figures 4.2 and 4.3 ) these observations suggest that a gradational contact occurs between the marl and limestone within the Lower Marl.

Furthermore, limestone samples that had the highest digestion times (Table 5.1) were generally situated in the middle of the limestone beds. This is likely due to the increased hardness of the limestones from a combination of increased silica and calcium carbonate content. When examining XRF results, it is evident that these samples correspond with higher $\mathrm{Si}[\mathrm{ex}]$ and $\mathrm{CaCO}_{3}$ fractions (Figure 7.2).

In most previous studies at Mead Stream, an individual 'representative' sample from each bed has been collected. In this high-resolution study, beds were further divided into subbeds before sampling. This has allowed the documentation of variation in both the fossil assemblages and the elemental content within a single bed. The resulting variability of paleontological and geochemical values across beds (Figures 6.1, 6.2 and 7.2) places uncertainty on the representative nature of samples that were collected at low resolution (one per bed) in previous studies of Mead Stream and similar outcrops.

\subsection{Productivity of foraminifera}

Although the correlation between increasing $\mathrm{CaCO}_{3}$ and $\mathrm{Si}$ [ex] percentages is a weak positive one (figure 7.3A), this association along with a decrease of Si[ex] in the marls (Figure 7.2) imply that most of the silica is biogenic. Correlation with the biogenic silica and $\mathrm{R} / \mathrm{F}$ ratios which both rise in the limestones, indicates no correlation (Figure $7.3 \mathrm{~B}$ ). In fact, radiolarians may be present in higher percentages than detected in the marls but dissolution of foraminifera during acid leaching in the limestones (as described in Section 5.4) presents overrepresentation of radiolarians. This is because radiolarians are less susceptible to the acetic acid due to their siliceous nature. 


\subsection{Multiproxy approach to examining the local expression of the EECO and hyperthermals}

\subsubsection{Integrated Paleontology and geochemistry for Set A}

Stable isotope analysis of Set A and Set B followed the global trend (Figure 8.1) although it should be noted that the more negative $\delta^{13} \mathrm{C}$ value observed in the marls could be explained by chemical alteration of the rock after deposition. Hence marls contain more ${ }^{12} \mathrm{C}$ in comparison to the limestones due to an increase in organic carbon from clay. Given that the isotope methodology measures carbonate and not organic carbon (see Section 4.3) then the negative values can be attributed to this diagenesis.

As noted earlier, Slotnick et al. (2012) defines the ' $\mathrm{J}$ ' CIE as occurring between $206.50 \mathrm{~m}$ and $207.83 \mathrm{~m}$, corrected to $206.35 \mathrm{~m}$ and $207.85 \mathrm{~m}$ respectively against the $2015 \mathrm{log}$. In this study's high-resolution data set, the location of the J CIE can be refined. Set $A \delta^{13} \mathrm{C}$ values decrease dramatically from $206.041 \mathrm{~m}$ (sample L2/1 (Figure 7.1)), indicating that the J hyperthermal begins earlier than indicated by Slotnick et al. (2012). The termination of the J hyperthermal documented from Set A isotopic data, occurs between $207.747 \mathrm{~m}$ (sample $\mathrm{L} 5 / 3$ ) and $207.849 \mathrm{~m}$ (L5/4) which is in agreement with the $2012 \delta^{13} \mathrm{C}$ data set (Slotnick et al., 2012).

Geochemical and paleontological data (including the parallel palynological study by Cooper (2018)) provide evidence that the J hyperthermal occurs as a two-stage event (Figure 8.1). Three distinct drops in $\delta^{13} \mathrm{C}$ are evident separating the CIE into 2 phases (Figure 7.1C). The lower stage is delineated by substantial increases in the sub-tropical warm-water dinocyst species Homotryblium tasmaniense (Cooper, 2018) occurring in dual peaks at 206.137206.300 m (L2/3-L2/8) and 206.699-206.829 m (L3/5-L3/M/1) and low tropical/subtropical Morozovella abundance. The upper stage is marked by a rise in Morozovella numbers (up to $25 \%$ of the assemblage) and the virtual absence of dinocysts (Cooper, 2018) throughout an entire limestone bed (207.000-207.400 m; L4). This Morozovella acme aligns with the lowest $\delta^{13} \mathrm{C}$ values from Set $A$. 
These findings indicate that the initial interval that is warm enough for dinocysts to bloom but not warm enough for Morozovella to become abundant in the microfossil assemblages. The upper interval of the J CIE likely represents much warmer conditions due to the pronounced increase in Morozovella numbers at $206.829 \mathrm{~m}$ (L3/M/1), and may have resulted in intolerable conditions for mid-latitude dinocysts at Mead Stream.

Significant increases in the radiolarian abundance, which consists entirely of spumellarians, (Figure 6.1) occurred from $206.460 \mathrm{~m}$ to $206.640 \mathrm{~m}$ (samples $L 3 / 1$ to $L 3 / 4$ ). This increase in radiolarian population sits between the two Homotryblium peaks synchronous with an increase in $\delta^{13} \mathrm{C}$ values from $206.460 \mathrm{~m}$ to $206.800 \mathrm{~m}$ (samples L3/1-L3/7; Figure 7.1). A similar rise in spumellarians coupled with the appearance of low latitudinal radiolarian species was observed across the PETM at Mead Stream (Hollis et al., 2005b; Hollis, 2006) and was thought to represent the southward expansion of subtropical waters. Therefore, the increase in spumellarians detected within the J hyperthermal may reflect a response to warming. 


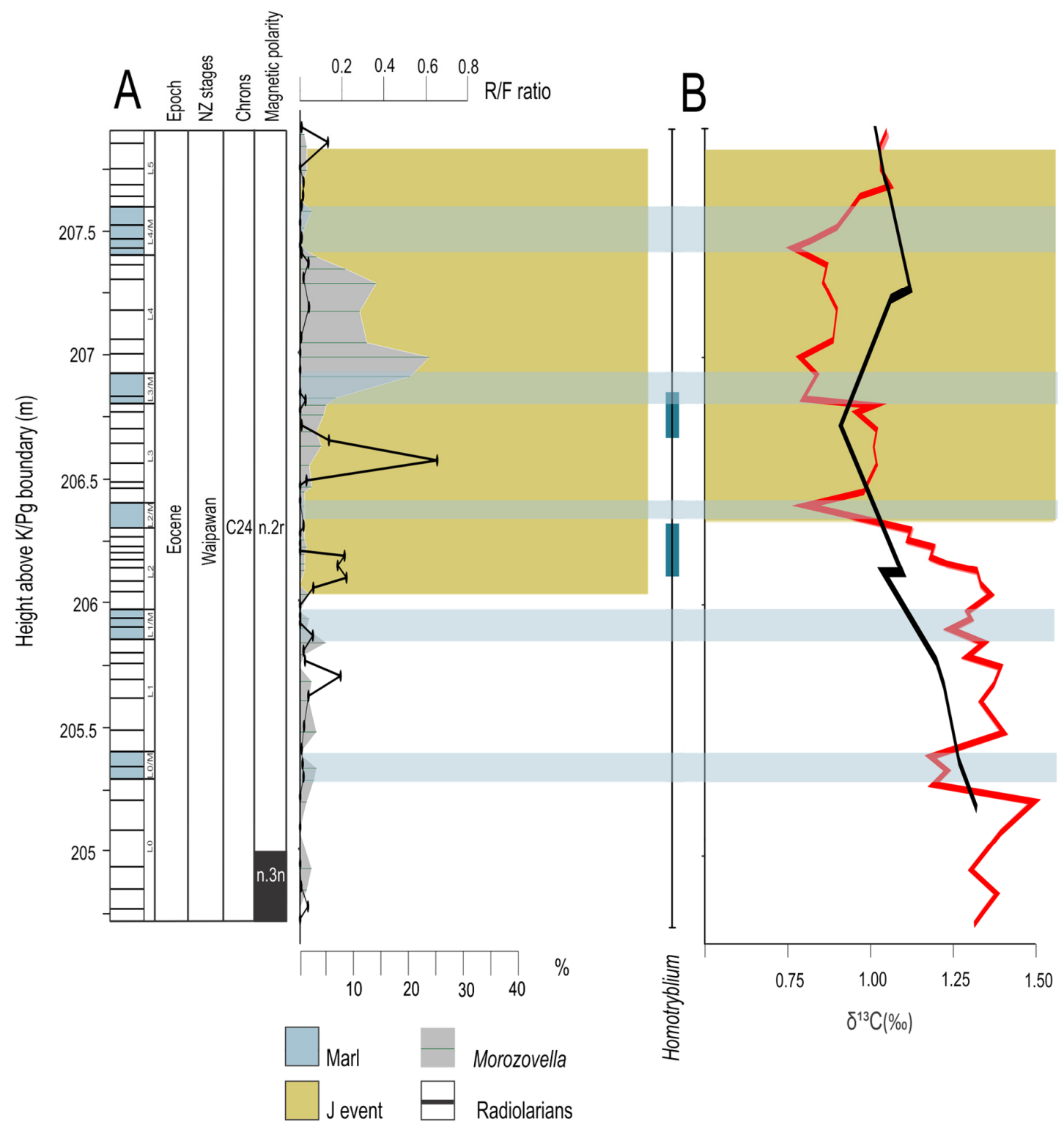

Figure 8.1 Summary of microfossil populations including dinocyst Homotryblium acmes (Cooper, 2018) across the J CIE. Graph A shows how the two microfossil components vary across this event (Morozovella relative abundance and R/F ratio). The refined position of the J hyperthermal from this study is shaded green. Graph B presents the aligning $\delta^{13} \mathrm{C}$ data from both Slotnick (2012, in black) and this study's data (red) along with the original definition of the J CIE (shaded green) by Slotnick et al. (2012). 


\subsubsection{Integrated Paleontology and geochemistry for Set B}

Slotnick et al.'s (2012) definition of global events expressed at Mead Stream include the J, K, L-1 and L-2 hyperthermals, but he suggested there could be more associated CIEs. In this study an additional L-3 CIE and possible hyperthermal event is proposed between 251.910 $\mathrm{m}(\mathrm{L} 44 / 6 \mathrm{~B})$ and $254.304 \mathrm{~m}(\mathrm{~L} 47 / 1)$. The $\delta^{13} \mathrm{C}$ data from Set B (see Figure 7.1B) displays a dramatic drop in $\delta^{13} \mathrm{C}$ within this interval.

The beginning of the L-3 hyperthermal is marked by an increase in Morozovella from low levels (<4\%) to $26 \%$ at $252.091 \mathrm{~m}$ (L44/M/1). In this marl sample, planktic foraminifera reach minimum abundance of $64 \%$. Because this percentage of planktic species was relatively low, the benthic assemblage this sample was examined for any clues to the environmental setting. The benthic fauna appears to be a lower-mid bathyal to outer shelf assemblage with no evidence of benthic foraminifera specimens having washed in from a shallower position on the shelf.

Immediately after the Morozovella acme, the genus Acarinina steadily increases from L45/4 (252.614 $\mathrm{m}$ ) to the Dw-Dm boundary at L46/M/1 (254.012 m). However, the Acarinina population following increased Morozovella numbers observed in Set A was not a comparable response, suggesting different environmental conditions and biotic responses between the $\mathrm{J}$ and L-3 hyperthermals.

Faunal turnover may explain the sudden increase in Subbotina populations and synchronised high Acarinina abundance observed at the Dw-Dm boundary. Interestingly no Homotryblium dinocyst blooms were observed by Cooper (2018) in the samples from Set B.

Percentages of radiolarians increase in the limestones with the greatest $R / F$ values occurring in the top two stratigraphic samples at $254.450 \mathrm{~m} \mathrm{(L46)}$ and $254.640 \mathrm{~m}$ (L/47) and equivalent to $9 \%$ and $20 \%$ respectively.

In summary, palaeontological and geochemical findings associated with the L-3 hyperthermal suggest a complex event and additional research in the associated sections in the Clarence valley may provide further paleoclimatic and paleoenvironmental insights. 


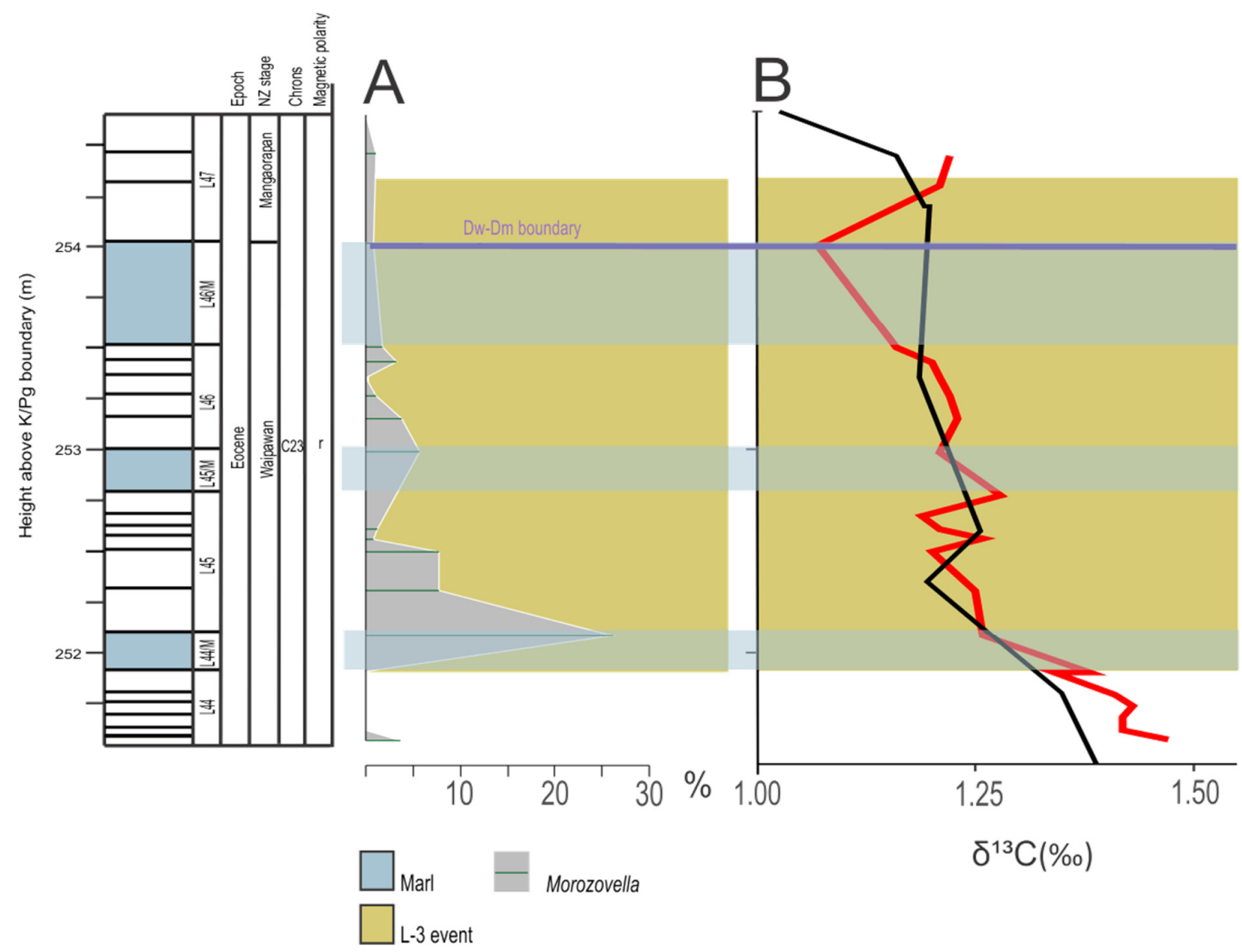

Figure 8.2 Summary of Morozovella populations across the proposed L-3 CIE. The position of this L-3 hyperthermal from this study's data is shaded green. Graph B presents the aligning $\delta^{13} \mathrm{C}$ data from both Slotnick (2012, in black) and this study's data (red).

\subsection{Paleoclimatic insights into marl and limestone alternations in the Lower Marl}

Elevated levels of organic matter (Cooper, 2018) coupled with a rise in terrigenous material from XRF results (Figure 7.2) are recorded in the marls in this study. This agrees with previous findings (Slotnick et al., 2012; Dallanave et al., 2015) which suggest a scenario of warmer climate, increased hydrological cycles, weathering of the continental shelf and accumulation of terrigenous sediment within the marls at Mead Stream. The percentages of terrigenous material in samples from Set B are slightly above values in Set A. Thus, the middle phase of the EECO (Set B) may indicate a warmer climate in comparison to the onset of the EECO (Set A). Higher percentages of Acarinina in Set B cannot provide definitive support for this theory without the identification of warm water Acarinina species. 
There is evidence of potential climate cycles within the Lower Marl in both sets A and B. An increase in Acarinina abundance coinciding with a decrease in Subbotina percentages is evident in all three marls samples within the J hyperthermal in Set A. The opposite situation is observed in the limestones. All three marls in Set B are within the proposed L-3 hyperthermal event, but in the first marl bed an increase in Subbotina and a decrease in Acarinina percentages are apparent. Again, the dominant genus is reversed in the second two marl beds where assemblages show peaks of Acarinina and lows of Subbotina and limestones have higher overall percentages of Subbotina and lower numbers of Acarinina in comparison to the marls.

At Mead Stream an increase in the Acarinina genus does not necessarily reflect the presence of warm-water or low latitudinal species. Despite poor foraminifera test preservation, a few Acarinina specimens were identified to species level in this thesis and previous studies aligning to the same stratigraphic heights (Strong et al., 1995 and Strong perscomm) but are cosmopolitan taxa. Included are Acarinina subsphaerica, A. coalingensis, and $A$. soldadoensis. A few individual specimens with tropical/subtropical affiliations (e.g. Acarinina subsphaerica) were among those picked and identified from sets $A$ and $B$, however confirmation of greater percentages of these warm water species within the marls is needed. Their presence could solely indicate a response to the elevated temperatures in the hyperthermal events J and L-3 as opposed to climate cycles within these CIEs.

Therefore, without the presence of a warm water Acarinina species in these marl samples, the suggestion that the marl and limestones alternating beds within the Lower Marl represent climate cycles cannot be confirmed without further examination of assemblages to species level.

A climatic signal was however confirmed within the J and L-3 CIEs evident from a significant rise of tropical/subtropical genus Morozovella of up to $25-26 \%$. These Morozovella acmes in Set $A$ and Set $B$ are indicative of a biotic response to oceanic warming. Global studies of the early Eocene revealed a decrease in Morozovella percentages and subsequent increase of Acarinina abundance (Lu \& Keller, 1995; Lu et al., 1998; Luciani et al., 2016; Luciani et al., 2017b, 2017a) contrary to results in this study. The three most recent of these studies compared several sites (e.g. Figure 8.3) and found this faunal turnover coinciding with the J 
hyperthermal at the initiation of the EECO at varying latitudes (Luciani et al., 2016; Luciani et al., 2017a, 2017b).

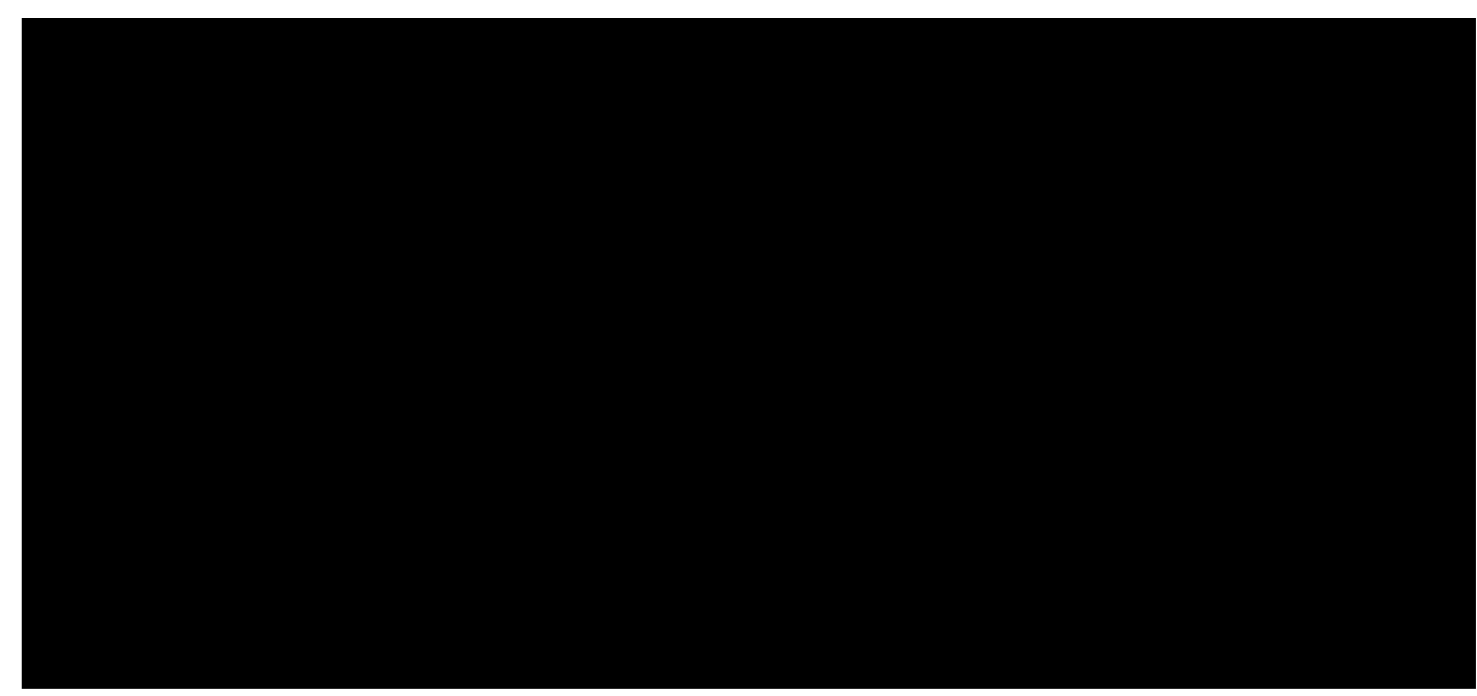

Figure 8.3: Example of Morozovella decline observed at the initiation of the EECO at DSDP low latitudinal Site 577. The decline of Morozovella is aligned with an increase in Acarinina percentages. The major decline in abundance occurs at the J CIE (Luciani et al., 2016).

A possible explanation for this subsequent decline in morozovellids is that temperatures during the EECO became too warm for them at these locations (Luciani et al., 2017b) although other factors such as ocean chemistry are likely contributors (Luciani et al., 2016). Further identification at species level need to be undertaken to fully understand the Morozovella populations at Mead Stream during the EECO, particularly in comparison to other locations and latitudes.

The appearance of the tropical/subtropical genus Morozovella in assemblages throughout the J and L-3 hyperthermals at Mead Stream could be explained by the southward expansion of warmer subtropical waters as suggested in other studies of the early Eocene (e.g. Hollis et al., 2009; Hollis et al., 2012). 


\section{CHAPTER 9: CONCLUSIONS and FUTURE WORK}

\subsection{Conclusions:}

This study examined microfossil assemblages from limestone-marl alternations at Mead Stream in Marlborough, Aotearoa/New Zealand. An acetic acid leaching method was developed to obtain foraminiferal and radiolarian assemblages from the indurated limestones. The resulting microfossil assemblages were examined semi-quantitively to produce a high-resolution detailed paleoenvironmental analyses of two intervals within the Lower Marl during the EECO. This paleontological assessment was integrated with geochemical analyses to provide paleoclimatological analysis of the alternating marl and limestone lithologies. The key findings are:

1. The acetic acid leaching technique for indurated limestones is reliable and resulting foraminiferal tests have a surface that shows significantly more detail and faunal features (aiding identification) than those subjected to standard processing techniques. The method is best performed as a multi-step process with several leach/washes cycles to extract the maximum yield of microfossils. Biogenic silica and calcium carbonate content may act as a guide for leaching times, although this needs to be investigated further.

2. The position of the J carbon isotopic excursion in the Lower Marl at Mead Stream has been further refined via carbon isotopic data to occur slightly earlier than published in previous studies. Paleontological and geochemical analysis provided evidence for a two- step J hyperthermal. The lower phase is marked by low abundance of Acarinina and Morozovella relative to the thermocline dwelling Subbotina and two Homotryblium dinocyst acmes. The latter stage suggests warmer temperatures characterised by acmes of the tropical/sub-tropical foraminiferal genus Morozovella and the absence of the dinocyst genus Homotryblium. 
3. A Carbon Isotopic Excursion and a corresponding increased abundance of the warmwater genus Morozovella indicates an additional CIE and possible hyperthermal event - L-3. Further work is required to fully document this CIE which may only be expressed locally.

4. Elevated levels of biogenic silica and calcium carbonate in limestones in the Lower Marl at Mead Stream suggest increased productivity, although this is not correlated to the occasional rise in radiolarian abundance observed in the limestones.

5. Foraminifera assemblages within both the J and L-3 CIEs at Mead Stream present increases in Acarinina and decreases in Subbotina within marls and the reverse in the limestones. However, climate cycles aligning with these alternations cannot be firmly established without analysis to species level.

6. The influx of the warm-water taxa Morozovella during the $\mathrm{J}$ and L-3 CIEs is consistent with the presence of a warmer water mass.

\subsection{Future work}

\section{Geochemistry}

In order to assess the possible link between biogenic silica and calcium carbonate leaching times additional samples from the Mead Stream Section and from other Clarence Valley outcrops may be processed. Reaction time of limestones in acetic acid could be determined or at least refined by XRF results for $\mathrm{Si}[\mathrm{ex}]$ and $\mathrm{CaCO}_{3}$.

\section{Further Paleontology}

Early Eocene strata from other similarly aged sections in the Clarence Valley could be analysed to further define the $\mathrm{J}$ and in particular the putative L-3 hyperthermal.

The first occurrence of Morozovella crater in previously examined limestones (Strong et al., 1995) defined the Dw-Dm boundary at bed L46/M (marl). This study also showed that this 
species was not present in marl bed 45 but limestone 46 had not been processed due to its indurated nature. Therefore, this study would enable a search through the 150-500um fraction of residue from the limestone sub beds $253.15 \mathrm{~m}$ to $253.50 \mathrm{~m}$ (L46/1-L46/5) for the presence for Morozovella crater. The counted assemblages did not feature this species, but as only a fraction of the residue was mounted on slides, this does not discount its presence.

Further analysis of benthic foraminifera (by picking out 100 or more specimens) may provide further paleoenvironmental interpretations - e.g. paleobathymetry. Especially as some of the preservation of the benthic specimens was average to good and identification to species level is possible.

Further examination of Acarinina populations within all samples aligned to the hyperthermals of both sets A and B. The identification of warm water Acarinina species could confirm the existence of climate cycles within the limestones and marls of the Lower Marl.

\section{Thin Sections}

Completing thin sections of for all 96 samples would provide insights into absolute abundance of microfossils throughout the Lower Marl. 


\section{REFERENCES}

Agnini, C., Macrì, P., Backman, J., Brinkhuis, H., Fornaciari, E., Giusberti, L., . . Speranza, F. (2009). An early Eocene carbon cycle perturbation at $52.5 \mathrm{Ma}$ in the Southern Alps: chronology and biotic response. Paleoceanography, 24(2).

Andrews, P. B., Gostin, V. A., Hampton, M. A., Margolis, S. V., \& Ovenshine, A. T. (1975). Synthesis - Sediments of the southwest Pacific Ocean, Indian Occean and Tasman Sea.

Barrett, P. (2003). Palaeoclimatology: cooling a continent. Nature, 421(6920), 221.

Berger, W., \& Diester-Haass, L. (1988). Paleoproductivity: the benthic/planktonic ratio in foraminifera as a productivity index. Marine Geology, 81(1-4), 15-25.

Bijl, P. K., Schouten, S., Sluijs, A., Reichart, G.-J., Zachos, J. C., \& Brinkhuis, H. (2009). Early Palaeogene temperature evolution of the southwest Pacific Ocean. Nature, 461(7265), 776-779.

Bolli, H. M., Beckmann, J.-P., \& Saunders, J. B. (1994). Benthic foraminiferal biostratigraphy of the south Caribbean region: Cambridge University Press.

Bowen, G. J., Beerling, D. J., Koch, P. L., Zachos, J. C., \& Quattlebaum, T. (2004). A humid climate state during the Palaeocene/Eocene thermal maximum. Nature, 432(7016), 495-499.

Bowen, G. J., \& Beitler Bowen, B. (2008). Mechanisms of PETM global change constrained by a new record from central Utah. Geology, 36(5), 379-382.

Bowen, G. J., Bralower, T. J., Delaney, M. L., Dickens, G. R., Kelly, D. C., Koch, P. L., . . Thomas, E. (2006). Eocene hyperthermal event offers insight into greenhouse warming. Eos, Transactions American Geophysical Union, 87(17), 165-169.

Buchanan, J. (1868). Kaikoura district. New Zealand Geological Survey report of geological explorations, 4, 3441.

Coccioni, R., \& Marsili, A. (2007). The response of benthic foraminifera to the K-Pg boundary biotic crisis at Elles (northwestern Tunisia). Palaeogeography, Palaeoclimatology, Palaeoecology, 255(1-2), 157-180.

Cooper, T. F. (2018). Early Eocene Palynology from Mead Stream, New Zealand. (MSc), Victoria University.

Cramer, B. S., Wright, J. D., Kent, D. V., \& Aubry, M. P. (2003). Orbital climate forcing of $\delta 13 C$ excursions in the late Paleocene-early Eocene (chrons C24n-C25n). Paleoceanography, 18(4).

Crampton, J. (2015). Mead Stream log 2015 GNS files James Crampton pers.comm.

Crampton, J., Laird, M., Nicol, A., Townsend, D., \& Van Dissen, R. (2003). Palinspastic reconstructions of southeastern Marlborough, New Zealand, for mid-Cretaceous-Eocene times. New Zealand Journal of Geology and Geophysics, 46(2), 153-175.

Crampton, J., \& Laird, M. G. (1997). Burnt Creek Formation and Late Cretaceous basin development in Marlborough, New Zealand. New Zealand Journal of Geology and Geophysics, 40(2), 199-222.

Creech, J. B., Baker, J. A., Hollis, C. J., Morgans, H. E., \& Smith, E. G. (2010). Eocene sea temperatures for the mid-latitude southwest Pacific from $\mathrm{Mg} / \mathrm{Ca}$ ratios in planktonic and benthic foraminifera. Earth and planetary science letters, 299(3-4), 483-495.

Crouch, E. M., Dickens, G. R., Brinkhuis, H., Aubry, M.-P., Hollis, C. J., Rogers, K. M., \& Visscher, H. (2003). The Apectodinium acme and terrestrial discharge during the Paleocene-Eocene thermal maximum: new palynological, geochemical and calcareous nannoplankton observations at Tawanui, New Zealand. Palaeogeography, Palaeoclimatology, Palaeoecology, 194(4), 387-403.

Crouch, E. M., Heilmann-Clausen, C., Brinkhuis, H., Morgans, H. E., Rogers, K. M., Egger, H., \& Schmitz, B. (2001). Global dinoflagellate event associated with the late Paleocene thermal maximum. Geology, 29(4), 315-318.

Crowell, J. C., \& Frakes, L. A. (1970). Phanerozoic glaciation and the causes of ice ages. American Journal of Science, 268(3), 193-224.

Cushman, J. A. (1948). Foraminifera, their classification and economic use.

Dallanave, E., Agnini, C., Bachtadse, V., Muttoni, G., Crampton, J. S., Strong, C. P., . . Slotnick, B. S. (2015). Early to middle Eocene magneto-biochronology of the southwest Pacific Ocean and climate influence on sedimentation: Insights from the Mead Stream section, New Zealand. Geological Society of America Bulletin, 127(5-6), 643-660. 
Dallanave, E., Bachtadse, V., Crouch, E. M., Tauxe, L., Shepherd, C. L., Morgans, H. E., ... Sugisaki, S. (2016). Constraining early to middle Eocene climate evolution of the southwest Pacific and Southern Ocean. Earth and planetary science letters, 433, 380-392.

De Wever, P., Dumitrica, P., Caulet, J. P., Nigrini, C., \& Caridroit, M. (2002). Radiolarians in the sedimentary record: CRC Press.

De Wever, P., O'dogherty, L., Caridroit, M., Dumitrica, P., Guex, J., Nigrini, C., \& Caulet, J.-P. (2003). Diversity of radiolarian families through time. Bulletin de la Société géologique de France, 174(5), 453-469.

DeConto, R. M., Galeotti, S., Pagani, M., Tracy, D., Schaefer, K., Zhang, T., . . Beerling, D. J. (2012). Past extreme warming events linked to massive carbon release from thawing permafrost. Nature, 484(7392), 87-91.

Dickens, G. R. (2011). Down the rabbit hole: Toward appropriate discussion of methane release from gas hydrate systems during the Paleocene-Eocene thermal maximum and other past hyperthermal events. Climate of the Past, 7(3), 831-846.

Dickens, G. R., Castillo, M. M., \& Walker, J. C. (1997). A blast of gas in the latest Paleocene: Simulating firstorder effects of massive dissociation of oceanic methane hydrate. Geology, 25(3), 259-262.

Dickens, G. R., O'Neil, J. R., Rea, D. K., \& Owen, R. M. (1995). Dissociation of oceanic methane hydrate as a cause of the carbon isotope excursion at the end of the Paleocene. Paleoceanography, 10(6), 965971.

Douglas, R. G., \& Savin, S. M. (1978). Oxygen isotopic evidence for the depth stratification of Tertiary and Cretaceous planktic foraminifera. Marine Micropaleontology, 3(2), 175-196.

Eldrett, J. S., Ma, C., Bergman, S. C., Ozkan, A., Minisini, D., Lutz, B., . . Kelly, A. E. (2015). Origin of limestonemarlstone cycles: astronomic forcing of organic-rich sedimentary rocks from the Cenomanian to early Coniacian of the Cretaceous Western Interior Seaway, USA. Earth and planetary science letters, 423, 98-113.

Escutia, C., Brinkhuis, H., \& Klaus, A. (2011). IODP Expedition 318: from greenhouse to icehouse at the Wilkes Land Antarctic margin. Scientific Drilling, 12, 15-23.

Fagel, N. (2007). Chapter four clay minerals, deep circulation and climate. Developments in marine geology, 1 , 139-184.

Fergusson, L. J. (1985). The mineralogy, geochemistry and origin of Lower Tertiary smectite-mudstones, East Coast deformed belt, New Zealand.

Field, B. D., \& Uruski, C. (1997). Cretaceous-Cenozoic geology and petroleum systems of the East Coast region, New Zealand (Vol. 1): Institute of Geological \& Nuclear Sciences.

Haast, J. v. (1871). On the geology of the Amuri district in the Provinces of Nelson and Marlborough. New Zealand Geological Survey Report of Geological Explorations, 1870-1871, 6, 25-46.

Hancock, H. J., Dickens, G. R., Strong, C., Hollis, C. J., \& Field, B. D. (2003). Foraminiferal and carbon isotope stratigraphy through the Paleocene-Eocene transition at Dee Stream, Marlborough, New Zealand. New Zealand Journal of Geology and Geophysics, 46(1), 1-19.

Hancock, H. J., Dickens, G. R., Thomas, E., \& Blake, K. L. (2007). Reappraisal of early Paleogene CCD curves: foraminiferal assemblages and stable carbon isotopes across the carbonate facies of Perth Abyssal Plain. International Journal of Earth Sciences, 96(5), 925-946.

Hansen, J., Sato, M., Ruedy, R., Lo, K., Lea, D. W., \& Medina-Elizade, M. (2006). Global temperature change. Proceedings of the National Academy of Sciences, 103(39), 14288-14293.

Hector, S. J. (1868). Abstract Report on the Progress of the Geological Survey of New Zealand During 1866-7: By authority, G. Didsbury, Government Printer.

Hines, B. R., Hollis, C. J., Atkins, C. B., Baker, J. A., Morgans, H. E., \& Strong, P. C. (2017). Reduction of oceanic temperature gradients in the early Eocene Southwest Pacific Ocean. Palaeogeography, Palaeoclimatology, Palaeoecology, 475, 41-54.

Hollis, C., Field, B., Jones, C., Strong, C., Wilson, G., \& Dickens, G. (2005a). Biostratigraphy and carbon isotope stratigraphy of uppermost Cretaceous-lower Cenozoic Muzzle Group in middle Clarence valley, New Zealand. Journal of the Royal Society of New Zealand, 35(3), 345-383.

Hollis, C., Hines, B., Littler, K., Villasante-Marcos, V., Kulhanek, D., Strong, C., . . Phillips, A. (2015). The Paleocene-Eocene thermal maximum at DSDP site 277, Campbell plateau, southern Pacific ocean.

Hollis, C., Rodgers, K., Strong, C., Field, B., \& Rogers, K. (2003a). Paleoenvironmental changes across the Cretaceous/Tertiary boundary in the northern Clarence Valley, southeastern Marlborough, New Zealand. New Zealand Journal of Geology and Geophysics, 46(2), 209-234. 
Hollis, C., Strong, C., Rodgers, K., \& Rogers, K. (2003b). Paleoenvironmental changes across the Cretaceous/Tertiary boundary at Flaxbourne River and Woodside Creek, eastern Marlborough, New Zealand. New Zealand Journal of Geology and Geophysics, 46(2), 177-197.

Hollis, C. J. (1993). Latest Cretaceous to Late Paleocene radiolarian biostratigraphy: A new zonation from the New Zealand region. Marine Micropaleontology, 21(4), 295-327.

Hollis, C. J. (1997a). Cretaceous-Paleocene Radiolaria from eastern Marlborough, New Zealand (Vol. 17): Institute of Geological \& Nuclear Sciences.

Hollis, C. J. (1997b). Integrated Paleogene biostratigraphy of DSDP site 277 (Leg 29): foraminifera, calcareous nannofossils, Radiolaria, and palynomorphs. Inst. Geol. Nuc. Sci. Rept. 97/07, 1-87.

Hollis, C. J. (2002). Biostratigraphy and paleoceanographic significance of Paleocene radiolarians from offshore eastern New Zealand. Marine Micropaleontology, 46(3), 265-316.

Hollis, C. J. (2006). Radiolarian faunal turnover through the Paleocene-eocene transition, Mead Stream, New Zealand Radiolaria (pp. 79-99): Springer.

Hollis, C. J., Dickens, G. R., Field, B. D., Jones, C. M., \& Strong, C. P. (2005b). The Paleocene-Eocene transition at Mead Stream, New Zealand: a southern Pacific record of early Cenozoic global change. Palaeogeography, Palaeoclimatology, Palaeoecology, 215(3), 313-343.

Hollis, C. J., Handley, L., Crouch, E. M., Morgans, H. E., Baker, J. A., Creech, J., . . Schouten, S. (2009). Tropical sea temperatures in the high-latitude South Pacific during the Eocene. Geology, 37(2), 99-102.

Hollis, C. J., Pascher, K. M., Hines, B. R., Littler, K., Kulhanek, D. K., Strong, C. P., . . Phillips, A. (2014a). Was the Early Eocene ocean unbearably warm or are the proxies unbelievably wrong? . Climatic and Biotic Events of the Paleogene 2014, CBEP 2014 : selected short notes and abstracts : Ferrara, Italy, July 1-6, 2014.

Hollis, C. J., Tayler, M. J., Andrew, B., Taylor, K. W., Lurcock, P., Bijl, P. K., . . Pancost, R. D. (2014b). Organicrich sedimentation in the South Pacific Ocean associated with Late Paleocene climatic cooling. EarthScience Reviews, 134, 81-97.

Hollis, C. J., Taylor, K. W., Handley, L., Pancost, R. D., Huber, M., Creech, J. B., . . Crampton, J. S. (2012). Early Paleogene temperature history of the Southwest Pacific Ocean: Reconciling proxies and models. Earth and planetary science letters, 349, 53-66.

Hornibrook, N. d. B. (1992). New Zealand Cenozoic marine paleoclimates: a review based on the distribution of some shallow water and terrestrial biota. Pacific Neogene: environment, evolution, and events. University of Tokyo Press, Tokyo, 83-106.

Hornibrook, N. d. B., Brazier, R. C., \& Strong, C. P. (1989). Manual of New Zealand Permian to Pleistocene foraminiferal biostratigraphy: New Zealand Geological Survey.

Huber, M., \& Caballero, R. (2011). The early Eocene equable climate problem revisited. Climate of the Past, $7(2), 603$.

Hutton, F. (1877). Report on the geology of the north-east portion of the South Island, from Cook Straits to the Rakaia. Report on Geological Explorations during 1873, 74, 27-58.

Jones, R. W. (2013). Foraminifera and their Applications: Cambridge University Press.

Jones, T. D., Lunt, D. J., Schmidt, D. N., Ridgwell, A., Sluijs, A., Valdes, P. J., \& Maslin, M. (2013). Climate model and proxy data constraints on ocean warming across the Paleocene-Eocene Thermal Maximum. Earth-Science Reviews, 125, 123-145.

Kennedy, E. M. (2003). Late Cretaceous and Paleocene terrestrial climates of New Zealand: leaf fossil evidence from South Island assemblages. New Zealand Journal of Geology and Geophysics, 46(2), 295-306.

Kennett, J., \& Stott, L. (1991). Abrupt deep sea warming, paleoceanographic changes and benthic extinctions at the end of the Paleocene.

King, P., Naish, T., Browne, G., Field, B., \& Edbrooke, S. (1999). Cretaceous to Recent sedimentary patterns in New Zealand. Institute of Geological \& Nuclear Sciences Folio Series, 1, folded chart.

Kling, S. A. (1998). Radiolaria Introduction to Marine Micropaleontology (Second Edition) (pp. 203-244): Elsevier.

Koch, P. L., Zachos, J. C., \& Gingerich, P. D. (1992). Correlation between isotope records in marine and continental carbon reservoirs near the Palaeocene/Eocene boundary. Nature, 358(6384), 319.

Kurtz, A., Kump, L., Arthur, M., Zachos, J., \& Paytan, A. (2003). Early Cenozoic decoupling of the global carbon and sulfur cycles. Paleoceanography, 18(4).

Laird, M. (1992). Cretaceous stratigraphy and evolution of the Marlborough segment of the East Coast region. Paper presented at the New Zealand Petroleum Conference Proceedings 1991.

Lazarus, D., Hollis, C., \& Apel, M. (2008). Patterns of opal and radiolarian change in the Antarctic midPaleogene: Clues to the origin of the Southern Ocean. Micropaleontology, 41-48. 
Leon-Rodriguez, L., \& Dickens, G. R. (2010). Constraints on ocean acidification associated with rapid and massive carbon injections: The early Paleogene record at ocean drilling program site 1215, equatorial Pacific Ocean. Palaeogeography, Palaeoclimatology, Palaeoecology, 298(3), 409-420.

Lipps, J. H. (1993). Fossil prokaryotes and protists: Blackwell Scientific Publications.

Lirer, F. (2000). A new technique for retrieving calcareous microfossils from lithified lime deposits. Micropaleontology, 365-369.

Liu, Z., Pagani, M., Zinniker, D., DeConto, R., Huber, M., Brinkhuis, H., . . Pearson, A. (2009). Global cooling during the Eocene-Oligocene climate transition. Science, 323(5918), 1187-1190.

Lourens, L. J., Sluijs, A., Kroon, D., Zachos, J. C., Thomas, E., Röhl, U., . . Raffi, I. (2005). Astronomical pacing of late Palaeocene to early Eocene global warming events. Nature, 435(7045), 1083-1087.

Lowenstein, T. K., \& Demicco, R. V. (2006). Elevated Eocene atmospheric CO2 and its subsequent decline. Science, 313(5795), 1928-1928.

Lu, G., \& Keller, G. (1995). Planktic foraminiferal faunal turnovers in the subtropical Pacific during the late Paleocene to early Eocene. The Journal of Foraminiferal Research, 25(2), 97-116.

Lu, G., Keller, G., \& Pardo, A. (1998). Stability and change in Tethyan planktic foraminifera across the Paleocene-Eocene transition. Marine Micropaleontology, 35(3-4), 203-233.

Luciani, V., D'Onofrio, R., Dickens, G. R., \& Wade, B. S. (2017a). Did Photosymbiont Bleaching Lead to the Demise of Planktic Foraminifer Morozovella at the Early Eocene Climatic Optimum? Paleoceanography, 32(11), 1115-1136.

Luciani, V., D'Onofrio, R., Dickens, G. R., \& Wade, B. S. (2017b). Planktic foraminiferal response to early Eocene carbon cycle perturbations in the southeast Atlantic Ocean (ODP Site 1263). Global and Planetary Change, 158, 119-133.

Luciani, V., Dickens, G. R., Backman, J., Fornaciari, E., Giusberti, L., Agnini, C., \& D'Onofrio, R. (2016). Major perturbations in the global carbon cycle and photosymbiont-bearing planktic foraminifera during the early Eocene. Climate of the Past, 12(4).

Luciani, V., Giusberti, L., Agnini, C., Backman, J., Fornaciari, E., \& Rio, D. (2007). The Paleocene-Eocene Thermal Maximum as recorded by Tethyan planktonic foraminifera in the Forada section (northern Italy). Marine Micropaleontology, 64(3), 189-214. doi:https://doi.org/10.1016/i.marmicro.2007.05.001

Matthews, K. J., Maloney, K. T., Zahirovic, S., Williams, S. E., Seton, M., \& Mueller, R. D. (2016). Global plate boundary evolution and kinematics since the late Paleozoic. Global and Planetary Change, 146, 226250.

Mclnerney, F. A., \& Wing, S. L. (2011). The Paleocene-Eocene Thermal Maximum: A perturbation of carbon cycle, climate, and biosphere with implications for the future. Annual Review of Earth and Planetary Sciences, 39, 489-516.

Meyers, S. R., Sageman, B. B., \& Hinnov, L. A. (2001). Integrated quantitative stratigraphy of the CenomanianTuronian Bridge Creek Limestone Member using evolutive harmonic analysis and stratigraphic modeling. Journal of Sedimentary Research, 71(4), 628-644.

Mildenhall, D. C. (1980). New Zealand Late Cretaceous and Cenozoic plant biogeography: a contribution. Palaeogeography, Palaeoclimatology, Palaeoecology, 31, 197-233.

Moore, P. R. (1988). Stratigraphy, composition and environment of deposition of the Whangai Formation and associated Late Cretaceous-Paleocene rocks, eastern North Island, New Zealand (Vol. 100): New Zealand Geological Survey.

Moore, P. R. (1989a). Lithological changes across the Cretaceous-Tertiary boundary in eastern North Island. New Zealand Geological Survey Record, 40, 41-47.

Moore, P. R. (1989b). Stratigraphy of the Waipawa Black Shale (Paleocene), eastern North Island, New Zealand (Vol. 38): New Zealand Dept. of Scientific and Industrial Research.

Morris, J. C. (1987). The stratigraphy of the Amuri limestone group, east Marlborough, New Zealand.

Mortimer, N. (2018). Evidence for a pre-Eocene proto-Alpine Fault through Zealandia. New Zealand Journal of Geology and Geophysics, 1-9.

Muttoni, G., \& Kent, D. V. (2007). Widespread formation of cherts during the early Eocene climate optimum. Palaeogeography, Palaeoclimatology, Palaeoecology, 253(3), 348-362.

Nicolo, M. J., Dickens, G. R., Hollis, C. J., \& Zachos, J. C. (2007). Multiple early Eocene hyperthermals: Their sedimentary expression on the New Zealand continental margin and in the deep sea. Geology, 35(8), 699-702.

Nürnberg, D., Bijma, J., \& Hemleben, C. (1996). Assessing the reliability of magnesium in foraminiferal calcite as a proxy for water mass temperatures. Geochimica et Cosmochimica Acta, 60(5), 803-814. 
Olsson, R. K., Berggren, W. A., Hemleben, C.-i., \& Huber, B. T. (1999). Atlas of Paleocene planktonic foraminifera.

Pachauri, R. K., Allen, M. R., Barros, V. R., Broome, J., Cramer, W., Christ, R., . . Dasgupta, P. (2014). Climate change 2014: synthesis report. Contribution of Working Groups I, II and III to the fifth assessment report of the Intergovernmental Panel on Climate Change: IPCC.

Pascher, K. M. (2017). Paleobiogeography of Eocene Radiolarians in the Southwest Pacific (Doctoral thesis, Victoria University, Wellington, New Zealand).

Pearson, P., Olsson, R., Huber, B., Hemleben, C., Berggren, W., Premoli Silva, I., . . Wade, B. (2005). Atlas of Eocene planktonic foraminifera. Epitome, 1, 274-274.

Pearson, P. N., van Dongen, B. E., Nicholas, C. J., Pancost, R. D., Schouten, S., Singano, J. M., \& Wade, B. S. (2007). Stable warm tropical climate through the Eocene Epoch. Geology, 35(3), 211-214.

Raine, J. I., Beu, A. G., Boyes, A. F., Campbell, H., Cooper, R. A., Crampton, J. S., . . Morgans, H. (2015). Revised calibration of the New Zealand Geological Timescale: NTGT2015/1: GNS Science Lower Hutt.

Rattenbury, M. S., Townsend, D., \& Johnston, M. R. (2006). Geology of the Kaikoura area. Institute of Geological \& Nuclear Sciences 1: 250000 Geological Map 13. 1 sheet.

Reay, M. B. (Cartographer). (1993). Geology of the middle Clarence valley. Institute of Geological and Nuclear Sciences geological map. 10

Reolid, M., \& Herrero, C. (2004). Evaluation of methods for retrieving foraminifera from indurated carbonates: application to the Jurassic spongiolithic limestone lithofacies of the Prebetic Zone (South Spain). Micropaleontology, 50(3), 307-312.

Riedel, W. (1967). Subclass Actinopoda, p. 291-298. Protozoa, the Fossil Record. Geological Society of London Publication. Google Scholar.

Schmitz, B., \& Pujalte, V. (2003). Sea-level, humidity, and land-erosion records across the initial Eocene thermal maximum from a continental-marine transect in northern Spain. Geology, 31(8), 689-692.

Schouten, S., Hopmans, E. C., Schefuß, E., \& Damste, J. S. S. (2002). Distributional variations in marine crenarchaeotal membrane lipids: a new tool for reconstructing ancient sea water temperatures? Earth and planetary science letters, 204(1-2), 265-274.

Schulte, P., Alegret, L., Arenillas, I., Arz, J. A., Barton, P. J., Bown, P. R., . . Cockell, C. S. (2010). The Chicxulub asteroid impact and mass extinction at the Cretaceous-Paleogene boundary. Science, 327(5970), 1214-1218.

Sexton, P. F., Wilson, P. A., \& Pearson, P. N. (2006). Microstructural and geochemical perspectives on planktic foraminiferal preservation:"Glassy" versus "Frosty". Geochemistry, Geophysics, Geosystems, 7(12).

Shackleton, N. J., \& Kennett, J. P. (1975). Paleotemperature history of the Cenozoic and the initiation of Antarctic glaciation: oxygen and carbon isotope analyses in DSDP Sites 277, 279, and 281. Initial reports of the deep sea drilling project, 29, 743-755.

Shepherd, C., \& Kulhanek, D. (2016). Eocene nannofossil biostratigraphy of the mid-Waipara River section, Canterbury Basin. New Zealand. J. Nannoplankton Res, 36, 33-59.

Shepherd, C. L. (2017). Early to middle Eocene calcareous nannofossils of the SW Pacific: Paleobiogeography and paleoclimate (doctoral thesis, Victoria University, Wellington, New Zealand).

Singer, A. (1984). The paleoclimatic interpretation of clay minerals in sediments-a review. Earth-Science Reviews, 21(4), 251-293.

Slotnick, B. S., Dickens, G. R., Nicolo, M. J., Hollis, C. J., Crampton, J. S., Zachos, J. C., \& Sluijs, A. (2012). Largeamplitude variations in carbon cycling and terrestrial weathering during the latest Paleocene and earliest Eocene: the record at Mead Stream, New Zealand. The journal of geology, 120(5), 487-505.

Sluijs, A., Bowen, G. J., Brinkhuis, H., Lourens, L. J., \& Thomas, E. (2007). The Palaeocene-Eocene Thermal Maximum super greenhouse: biotic and geochemical signatures, age models and mechanisms of global change. Deep time perspectives on climate change: Marrying the signal from computer models and biological proxies, 323-347.

Sluijs, A., Schouten, S., Pagani, M., Woltering, M., Brinkhuis, H., Damsté, J. S. S., . . Stein, R. (2006). Subtropical Arctic Ocean temperatures during the Palaeocene/Eocene thermal maximum. Nature, 441(7093), 610.

Strogen, D. P., Seebeck, H., Nicol, A., \& King, P. R. (2017). Two-phase Cretaceous-Paleocene rifting in the Taranaki Basin region, New Zealand; implications for Gondwana break-up. Journal of the Geological Society, 174(5), 929-946.

Strong, C., \& Beggs, J. (1990). Late Cretaceous-early Paleogene stratigraphic sequence in Marlborough and possible offshore seismic equivalents. Paper presented at the 1989 New Zealand Oil Exploration 
Conference Proceedings. Petroleum and Geothermal Unit, Energy and Resources Division, Ministry of Commerce.

Strong, C., Hollis, C., \& Wilson, G. (1995). Foraminiferal, radiolarian, and dinoflagellate biostratigraphy of Late Cretaceous to middle Eocene pelagic sediments (Muzzle group), Mead Stream, Marlborough, New Zealand. New Zealand Journal of Geology and Geophysics, 38(2), 171-209.

Strong, C., Hollis, C., \& Wilson, G. J. (1991). Foraminiferal, radiolarian and dinoflagellate biostratigraphy of Muzzle Group limestones (Upper Cretaceous to Middle Eocene) at Mead Stream, inland Marlborough, East Coast CCP: DSIR Geology \& Geophysics.

Sutherland, R., King, P., Wood, R., Hill, K., \& Bernecker, T. (2001). Tectonic evolution of Cretaceous rift basins in south-eastern Australia and New Zealand: implications for exploration risk assessment: Melbourne.

Svensen, H., Planke, S., \& Corfu, F. (2010). Zircon dating ties NE Atlantic sill emplacement to initial Eocene global warming. Journal of the Geological Society, 167(3), 433-436.

Svensen, H., Planke, S., Malthe-Sørenssen, A., Jamtveit, B., Myklebust, R., Eidem, T. R., \& Rey, S. S. (2004). Release of methane from a volcanic basin as a mechanism for initial Eocene global warming. Nature, 429(6991), 542-545.

Thomas, E., \& Shackleton, N. J. (1996). The Paleocene-Eocene benthic foraminiferal extinction and stable isotope anomalies. Geological Society, London, Special Publications, 101(1), 401-441.

Tjalsma, R. C., \& G.P., L. (1983). Paleocene-Eocene bathyal and abyssal benthic foraminifera from the Atlantic Ocean. Micropaleontology, 4, 94p.

Torsvik, T. H., Van der Voo, R., Preeden, U., Mac Niocaill, C., Steinberger, B., Doubrovine, P. V., ... Tohver, E. (2012). Phanerozoic polar wander, palaeogeography and dynamics. Earth-Science Reviews, 114(3-4), 325-368.

Turner, S. K., Sexton, P. F., Charles, C. D., \& Norris, R. D. (2014). Persistence of carbon release events through the peak of early Eocene global warmth. Nature Geoscience, 7(10), 748-751.

Van der Zwaan, G., Jorissen, F., \& De Stigter, H. (1990). The depth dependency of planktonic/benthic foraminiferal ratios: constraints and applications. Marine Geology, 95(1), 1-16.

Van Dissen, R., \& Yeats, R. S. (1991). Hope fault, Jordan thrust, and uplift of the seaward Kaikoura Range, New Zealand. Geology, 19(4), 393-396.

Van Morkhoven, F. P., Berggren, W. A., Edwards, A. S., \& Oertli, H. (1986). Cenozoic cosmopolitan deep-water benthic foraminifera (Vol. 11): Elf Aquitaine.

Webb, P. N. (1966). New Zealand Late Cretaceous foraminifera and stratigraphy. (PhD), State University of Utrecht. (NZMS260: J43; 144)

Webb, P. N. (1971). New Zealand Late Cretaceous (Haumurian) foraminifera and stratigraphy: a summary. New Zealand Journal of Geology and Geophysics, 14(4), 795-828.

Zachos, J., Pagani, M., Sloan, L., Thomas, E., \& Billups, K. (2001). Trends, rhythms, and aberrations in global climate $65 \mathrm{Ma}$ to present. Science, 292(5517), 686-693.

Zachos, J. C., Dickens, G. R., \& Zeebe, R. E. (2008). An early Cenozoic perspective on greenhouse warming and carbon-cycle dynamics. Nature, 451(7176), 279-283.

Zachos, J. C., Röhl, U., Schellenberg, S. A., Sluijs, A., Hodell, D. A., Kelly, D. C., . . Lourens, L. J. (2005). Rapid acidification of the ocean during the Paleocene-Eocene thermal maximum. Science, 308(5728), 16111615.

Zeebe, R. E., Ridgwell, A., \& Zachos, J. C. (2016). Anthropogenic carbon release rate unprecedented during the past 66 million years. Nature Geoscience.

Zeebe, R. E., \& Zachos, J. C. (2013). Long-term legacy of massive carbon input to the Earth system: Anthropocene versus Eocene. Philosophical Transactions of the Royal Society of London A: Mathematical, Physical and Engineering Sciences, 371(2001). 


\section{APPENDIX A: Sample numbers and paleontology results}

\begin{tabular}{|c|c|c|c|c|c|c|c|c|c|}
\hline \multicolumn{4}{|c|}{ Sample numbers and heights } & \multicolumn{6}{|c|}{ Paleonotology } \\
\hline $\begin{array}{l}\text { Height } \\
(\mathrm{m})\end{array}$ & $\begin{array}{c}\text { Sample } \\
\#\end{array}$ & GNS FRED \# & GNS F \# & $\begin{array}{c}\% \\
\text { Acar }\end{array}$ & $\begin{array}{c}\% \\
\text { Sub }\end{array}$ & $\begin{array}{c}\% \\
M z v\end{array}$ & $\%$ OP & $\%$ planktics & $\begin{array}{c}\mathrm{F} / \mathrm{R} \\
\text { ratio }\end{array}$ \\
\hline & Trial Set & & & & & & & & \\
\hline 226.41 & L25 & P30/f1472 & F38605 & 34 & 46 & 3 & 17 & 89 & 0.11 \\
\hline 226.16 & L24/M & $\mathrm{f} 1571$ & F36694 & 68 & 14 & 0 & 18 & 80 & 0.12 \\
\hline 225.80 & L24 & $f 1471$ & F38604 & 38 & 53 & 1 & 8 & 87 & 1.51 \\
\hline 224.88 & $\mathrm{~L} 23 / \mathrm{M}$ & $\mathrm{f} 1570$ & F36693 & 68 & 19 & 7 & 7 & 84 & 0.02 \\
\hline 224.57 & L23 & $\mathrm{f} 1470$ & F38603 & - & - & - & - & - & - \\
\hline 224.35 & $\mathrm{~L} 22 / \mathrm{M}$ & f1569 & F36692 & 61 & 19 & 1 & 19 & 88 & 0.07 \\
\hline 223.78 & L22 & f1469 & F38602 & - & - & - & - & - & - \\
\hline 223.60 & $\mathrm{~L} 21 / \mathrm{M}$ & missing & F36692 & 71 & 16 & 2 & 11 & 90 & 0.02 \\
\hline 222.80 & L21 & f1468 & F38601 & - & - & - & - & - & - \\
\hline 222.52 & L20/M & f1568 & F36691 & 55 & 32 & 3 & 9 & 94 & 0.04 \\
\hline 221.95 & $\mathrm{~L} 20$ & f1467 & F38600 & - & - & - & - & - & - \\
\hline 221.47 & L19/M & f1567 & F36690 & 58 & 32 & 1 & 9 & 88 & 0.03 \\
\hline 220.82 & L19 & f1466 & F38599 & - & - & - & - & - & - \\
\hline 220.40 & L18/M & f1566 & F36689 & 52 & 26 & 1 & 21 & 98 & 0.01 \\
\hline 220.10 & L18 & f1465 & F38598 & - & - & - & - & - & - \\
\hline 219.96 & L17/M & f1565 & F36688 & 74 & 17 & 2 & 7 & 93 & 0.03 \\
\hline 219.53 & L17 & $\mathrm{f} 1464$ & F38597 & 71 & 21 & 0 & 9 & 95 & 0.11 \\
\hline 218.94 & L16/M & $\mathrm{f} 1564$ & F36687 & 67 & 19 & 1 & 14 & 95 & 0.04 \\
\hline 218.28 & L16 & f1463 & F38596 & 31 & 56 & 0 & 13 & 91 & 0.17 \\
\hline 217.84 & L15/M & f1563 & F36686 & 67 & 16 & 1 & 16 & 93 & 0.03 \\
\hline \multirow[t]{2}{*}{217.52} & L15 & $\mathrm{f} 1462$ & F38595 & 52 & 33 & 1 & 13 & 93 & 0.12 \\
\hline & Set A & & & & & & & & \\
\hline 204.714 & LO/1 & P30/f1838 & F50088 & 15 & 68 & 0 & 5 & 16 & 0 \\
\hline 204.765 & LO/2 & P30/f1839 & F50089 & 11 & 69 & 0 & 14 & 13 & 0 \\
\hline 204.845 & LO/3 & P30/f1840 & F50090 & 14 & 57 & 1 & 12 & 8 & 2 \\
\hline 204.935 & LO/4 & P30/f1841 & F50091 & 23 & 55 & 2 & 9 & 26 & 3 \\
\hline 205.085 & LO/5 & P30/f1842 & F50092 & 9 & 70 & 0 & 10 & 20 & 0 \\
\hline 205.205 & LO/6 & P30/f1843 & F50093 & 34 & 51 & 1 & 6 & 14 & 2 \\
\hline 205.290 & LO/7 & P30/f1844 & F50094 & 14 & 52 & 3 & 24 & 7 & 5 \\
\hline 205.340 & LO/M/1 & P30/f1845 & F50095 & 17 & 34 & 3 & 21 & 27 & 9 \\
\hline 205.400 & $\mathrm{LO} / \mathrm{M} / 2$ & P30/f1846 & F50096 & 18 & 46 & 0 & 22 & 29 & 0 \\
\hline 205.486 & $\mathrm{~L} 1 / 1$ & P30/f1847 & F50097 & 7 & 73 & 3 & 8 & 11 & 4 \\
\hline 205.614 & $\mathrm{~L} 1 / 2$ & P30/f1848 & F50098 & 18 & 68 & 1 & 8 & 11 & 2 \\
\hline 205.689 & $\mathrm{~L} 1 / 3$ & P30/f1849 & F50099 & 40 & 40 & 2 & 13 & 22 & 5 \\
\hline 205.754 & $\mathrm{~L} 1 / 4$ & P30/f1851 & F50100 & 38 & 44 & 0 & 10 & 20 & 0 \\
\hline 205.796 & $\mathrm{~L} 1 / 5$ & P30/f1852 & F50101 & 30 & 53 & 1 & 9 & 20 & 2 \\
\hline 205.850 & $\mathrm{~L} 1 / 6$ & P30/f1853 & F50102 & 32 & 39 & 5 & 16 & 15 & 11 \\
\hline 205.900 & L1/M/1 & P30/f1854 & F50103 & 12 & 57 & 1 & 17 & 22 & 2 \\
\hline
\end{tabular}




\begin{tabular}{|c|c|c|c|c|c|c|c|c|c|}
\hline 205.935 & L1/M/2 & P30/f1855 & F50104 & 19 & 56 & 2 & 11 & 18 & 3 \\
\hline 205.970 & L1/M/3 & P30/f1856 & F50105 & 21 & 56 & 0 & 9 & 15 & 0 \\
\hline 206.041 & L2/1 & P30/f1857 & F50106 & 9 & 63 & 2 & 23 & 10 & 2 \\
\hline 206.084 & $\mathrm{~L} 2 / 2$ & P30/f1858 & F50107 & 21 & 52 & 0 & 26 & 10 & 0 \\
\hline 206.137 & $L 2 / 3$ & P30/f1859 & F50108 & 23 & 51 & 1 & 25 & 21 & 2 \\
\hline 206.172 & $\mathrm{~L} 2 / 4$ & P30/f1860 & F50109 & 9 & 72 & 1 & 16 & 19 & 1 \\
\hline 206.201 & $\mathrm{~L} 2 / 5$ & P30/f1861 & F50110 & 30 & 30 & 1 & 37 & 13 & 3 \\
\hline 206.226 & $\mathrm{~L} 2 / 6$ & P30/f1862 & F50111 & 28 & 29 & 1 & 40 & 9 & 3 \\
\hline 206.265 & $\mathrm{~L} 2 / 7$ & P30/f1863 & F50112 & 40 & 47 & 1 & 2 & 13 & 2 \\
\hline 206.300 & L2/8 & P30/f1864 & F50113 & 21 & 63 & 1 & 12 & 10 & 1 \\
\hline 206.401 & $\mathrm{~L} 2 / \mathrm{M} / 1$ & P30/f1865 & F50114 & 46 & 42 & 1 & 6 & 18 & 1 \\
\hline 206.460 & $\mathrm{~L} 3 / 1$ & P30/f1866 & F50115 & 14 & 52 & 1 & 24 & 12 & 1 \\
\hline 206.485 & $\mathrm{~L} 3 / 2$ & P30/f1867 & F50116 & 16 & 60 & 2 & 14 & 20 & 3 \\
\hline 206.561 & $L 3 / 3$ & P30/f1868 & F50117 & 11 & 57 & 2 & 19 & 13 & 3 \\
\hline 206.640 & $\mathrm{~L} 3 / 4$ & P30/f1869 & F50118 & 16 & 40 & 4 & 31 & 18 & 9 \\
\hline 206.699 & $\mathrm{~L} 3 / 5$ & P30/f1870 & F50119 & 12 & 43 & 3 & 29 & 26 & 7 \\
\hline 206.766 & L3/6 & P30/f1871 & F50120 & 11 & 53 & 4 & 20 & 16 & 7 \\
\hline 206.800 & L3/7 & P30/f1872 & F50121 & 15 & 44 & 5 & 23 & 13 & 10 \\
\hline 206.829 & L3/M/1 & P30/f1873 & F50122 & 35 & 37 & 7 & 14 & 19 & 16 \\
\hline 206.922 & $\mathrm{~L} 3 / \mathrm{M} / 2$ & P30/f1874 & F50123 & 25 & 41 & 21 & 5 & 9 & 34 \\
\hline 207.000 & L4/1 & P30/f1875 & F50124 & 20 & 49 & 25 & 4 & 6 & 33 \\
\hline 207.059 & $L 4 / 2$ & P30/f1876 & F50125 & 30 & 44 & 13 & 8 & 2 & 22 \\
\hline 207.176 & L4/3 & P30/f1877 & F50126 & 7 & 54 & 11 & 14 & 10 & 17 \\
\hline 207.302 & L4/4 & P30/f1878 & F50127 & 13 & 43 & 15 & 17 & 4 & 25 \\
\hline 207.361 & $L 4 / 5$ & P30/f1879 & F50128 & 10 & 56 & 8 & 5 & 7 & 13 \\
\hline 207.400 & L4/6 & P30/f1880 & F50129 & 20 & 60 & 3 & 10 & 12 & 5 \\
\hline 207.428 & L4/M/1 & P30/f1881 & F50130 & 12 & 54 & 1 & 23 & 8 & 2 \\
\hline 207.465 & L4/M/2 & P30/f1882 & F50131 & 17 & 49 & 0 & 21 & 9 & 0 \\
\hline 207.520 & L4/M/3 & P30/f1883 & F50132 & 13 & 58 & 1 & 15 & 7 & 1 \\
\hline 207.594 & L4/M/4 & P30/f1884 & F50133 & 23 & 43 & 2 & 24 & 10 & 5 \\
\hline 207.636 & L5/1 & P30/f1909 & F50134 & 11 & 60 & 0 & 14 & 14 & 0 \\
\hline 207.682 & $L 5 / 2$ & P30/f1910 & F50135 & 10 & 64 & 0 & 13 & 14 & 0 \\
\hline 207.747 & $L 5 / 3$ & P30/f1911 & F50136 & 20 & 52 & 1 & 17 & 15 & 2 \\
\hline 207.849 & $\mathrm{~L} 5 / 4$ & P30/f1912 & F50137 & 8 & 73 & 1 & 12 & 22 & 1 \\
\hline \multirow[t]{2}{*}{207.900} & $\mathrm{~L} 5 / 5$ & P30/f1850 & F50138 & 4 & 65 & 1 & 18 & 13 & 1 \\
\hline & Set $B$ & & & & & & & & \\
\hline 251.573 & L44/1 & P30/f1885 & F50139 & 53 & 30 & 3 & 5.6075 & 20 & 10 \\
\hline 251.618 & L44/2 & P30/f1886 & F50140 & 64 & 17 & 0 & 5.7471 & 16 & 0 \\
\hline 251.681 & L44/3 & P30/f1887 & F50141 & 17 & 62 & 0 & 6.9767 & 28 & 0 \\
\hline 251.743 & L44/4 & P30/f1888 & F50142 & $\mathrm{N} / \mathrm{A}$ & $\mathrm{N} / \mathrm{A}$ & $\mathrm{N} / \mathrm{A}$ & $\mathrm{N} / \mathrm{A}$ & $\mathrm{N} / \mathrm{A}$ & $\mathrm{N} / \mathrm{A}$ \\
\hline 251.792 & L44/5 & P30/f1889 & F50143 & $\mathrm{N} / \mathrm{A}$ & $\mathrm{N} / \mathrm{A}$ & $\mathrm{N} / \mathrm{A}$ & $\mathrm{N} / \mathrm{A}$ & $\mathrm{N} / \mathrm{A}$ & $\mathrm{N} / \mathrm{A}$ \\
\hline 251.900 & L44/6A & P30/f1890 & F50144 & 48 & 34 & 0 & 5.1724 & 27 & 0 \\
\hline 251.910 & L44/6B & P30/f1891 & F50145 & 43 & 38 & 0 & 7.9545 & 24 & 0 \\
\hline 252.091 & L44/M/1 & P30/f1892 & F50146 & 15 & 56 & 25 & 0.9346 & 36 & 31 \\
\hline 252.306 & L45/1 & P30/f1893 & F50147 & 30 & 45 & 7 & 4.2735 & 9 & 13 \\
\hline 252.496 & $\mathrm{~L} 45 / 2$ & P30/f1894 & F50148 & 37 & 39 & 7 & 5.8252 & 7 & 15 \\
\hline 252.565 & $L 45 / 3$ & P30/f1895 & F50149 & 33 & 49 & 1 & 3.5714 & 2 & 2 \\
\hline
\end{tabular}




\begin{tabular}{|c|c|c|c|c|c|c|c|c|c|}
252.614 & L45/4 & P30/f1896 & F50150 & 22 & 45 & 1 & 15 & 12 & 2 \\
\hline 252.672 & L45/5 & P30/f1897 & F50151 & N/A & N/A & N/A & N/A & N/A & N/A \\
\hline 252.780 & L45/6 & P30/f1898 & F50152 & N/A & N/A & N/A & N/A & N/A & N/A \\
\hline 252.990 & L45/M/1 & P30/f1899 & F50153 & 57 & 32 & 6 & 1.9048 & 20 & 15 \\
\hline 253.148 & L46/1 & P30/f1900 & F50154 & 27 & 38 & 3 & 6.4103 & 20 & 7 \\
\hline 253.258 & L46/2 & P30/f1901 & F50155 & 32 & 45 & 1 & 5.8824 & 4 & 2 \\
\hline 253.353 & L46/3 & P30/f1902 & F50156 & 53 & 38 & 0 & 2.8846 & 3 & 0 \\
\hline 253.426 & L46/4 & P30/f1903 & F50157 & 45 & 40 & 3 & 4.3478 & 11 & 7 \\
\hline 253.500 & L46/5 & P30/f1904 & F50158 & 38 & 50 & 2 & 7.4074 & 8 & 3 \\
\hline 254.012 & L46/M/1 & P30/f1905 & F50159 & 66 & 24 & 1 & 3.937 & 11 & 3 \\
\hline 254.304 & L47/1 & P30/f1906 & F50160 & N/A & N/A & N/A & N/A & N/A & N/A \\
\hline 254.450 & L47/2 & P30/f1907 & F50161 & 24 & 55 & 1 & 5.618 & 8 & 2 \\
\hline 254.640 & L47/3 & P30/f1908 & F50162 & 35 & 42 & 0 & 3.6364 & 20 & 0 \\
\hline
\end{tabular}




\section{APPENDIX B: Geochemistry results}

\begin{tabular}{|c|c|c|c|c|c|c|c|c|c|}
\hline $\begin{array}{c}\text { Sample } \\
\#\end{array}$ & $\begin{array}{c}\text { Height } \\
\pm \mathrm{K} / \mathrm{Pg} \\
\text { (m) }\end{array}$ & $\delta^{13} \mathrm{C}$ & $\begin{array}{c}\mathrm{Si} \\
\text { Compound } \\
\text { Level (\%) }\end{array}$ & $\begin{array}{c}\text { Al } \\
\text { Compound } \\
\text { Level (\%) }\end{array}$ & $\begin{array}{c}\text { Fe } \\
\text { Compound } \\
\text { Level (\%) }\end{array}$ & $\begin{array}{c}\text { Ca } \\
\text { Compound } \\
\text { Level (\%) }\end{array}$ & TRG & Si[exc] & $\mathrm{CaCO}_{3}$ \\
\hline LO/1 & 204.714 & 1.27 & 12.58 & 1.26 & 0.51 & 38.64 & 9.04 & 9.44 & 81.52 \\
\hline LO/2 & 204.765 & 1.30 & 8.36 & 0.71 & 0.42 & 40.27 & 5.31 & 6.53 & 88.16 \\
\hline LO/3 & 204.845 & 1.34 & 10.37 & 0.42 & 0.32 & 37.35 & 3.29 & 11.02 & 85.69 \\
\hline LO/4 & 204.935 & 1.26 & 11.45 & 0.61 & 0.36 & 41.18 & 4.32 & 10.27 & 85.40 \\
\hline LO/5 & 205.085 & 1.35 & 12.50 & 0.75 & 0.29 & 41.65 & 5.13 & 10.58 & 84.29 \\
\hline LO/6 & 205.205 & 1.45 & 11.78 & 0.68 & 0.29 & 38.28 & 5.08 & 10.91 & 84.00 \\
\hline LO/7 & 205.290 & 1.15 & 14.12 & 0.67 & 0.28 & 38.58 & 4.82 & 13.40 & 81.78 \\
\hline LO/M/1 & 205.340 & 1.19 & 20.65 & 3.72 & 1.23 & 32.90 & 26.16 & 5.67 & 68.17 \\
\hline LO/M/2 & 205.400 & 1.14 & 20.57 & 3.58 & 1.51 & 26.53 & 29.13 & 7.25 & 63.62 \\
\hline L1/1 & 205.486 & 1.36 & 10.18 & 0.70 & 0.33 & 40.89 & 5.06 & 8.51 & 86.43 \\
\hline $\mathrm{L} 1 / 2$ & 205.614 & 1.29 & 16.09 & 0.59 & 0.23 & 37.26 & 4.30 & 16.21 & 79.49 \\
\hline $\mathrm{L} 1 / 3$ & 205.689 & 1.33 & 16.78 & 0.53 & 0.23 & 35.46 & 3.98 & 17.92 & 78.10 \\
\hline $\mathrm{L} 1 / 4$ & 205.754 & 1.35 & 14.22 & 0.48 & 0.24 & 38.78 & 3.42 & 14.47 & 82.11 \\
\hline $\mathrm{L} 1 / 5$ & 205.796 & 1.25 & 12.19 & 0.46 & 0.25 & 39.72 & 3.29 & 12.22 & 84.49 \\
\hline L1/6 & 205.850 & 1.30 & 12.42 & 0.67 & 0.29 & 43.22 & 4.48 & 10.55 & 84.98 \\
\hline $\mathrm{L} 1 / \mathrm{M} / 1$ & 205.900 & 1.20 & 20.08 & 3.43 & 1.12 & 32.41 & 24.68 & 6.59 & 68.72 \\
\hline $\mathrm{L} 1 / \mathrm{M} / 2$ & 205.935 & 1.26 & 18.56 & 2.51 & 0.89 & 33.11 & 18.47 & 9.65 & 71.88 \\
\hline L1/M/3 & 205.970 & 1.25 & 19.67 & 3.12 & 0.30 & 32.05 & 22.92 & 7.79 & 69.29 \\
\hline $\mathrm{L} 2 / 1$ & 206.041 & 1.32 & 13.05 & 0.62 & 0.28 & 36.08 & 4.79 & 13.24 & 81.96 \\
\hline $\mathrm{L} 2 / 2$ & 206.084 & 1.29 & 8.70 & 0.58 & 0.27 & 42.10 & 4.15 & 7.34 & 88.51 \\
\hline$L 2 / 3$ & 206.137 & 1.28 & 10.98 & 0.47 & 0.24 & 38.84 & 3.48 & 11.10 & 85.43 \\
\hline $\mathrm{L} 2 / 4$ & 206.172 & 1.19 & 14.27 & 0.63 & 0.23 & 37.37 & 4.68 & 14.10 & 81.22 \\
\hline $\mathrm{L} 2 / 5$ & 206.201 & 1.14 & 16.63 & 0.46 & 0.29 & 39.36 & 3.17 & 16.74 & 80.09 \\
\hline L2/6 & 206.226 & 1.15 & 13.76 & 1.09 & 0.45 & 39.71 & 7.61 & 10.55 & 81.84 \\
\hline $\mathrm{L} 2 / 7$ & 206.265 & 1.07 & 11.78 & 1.17 & 0.45 & 38.33 & 8.58 & 8.30 & 83.11 \\
\hline L2/8 & 206.300 & 1.08 & 10.93 & 0.93 & 0.46 & 37.13 & 7.15 & 8.85 & 84.00 \\
\hline $\mathrm{L} 2 / \mathrm{M}$ & 206.401 & 0.77 & 27.40 & 5.12 & 1.64 & 24.77 & 38.38 & 7.00 & 54.61 \\
\hline L3/1 & 206.460 & 0.94 & 15.44 & 1.45 & 0.61 & 35.23 & 10.83 & 11.49 & 77.68 \\
\hline $\mathrm{L} 3 / 2$ & 206.485 & 0.95 & 12.05 & 0.46 & 0.29 & 40.95 & 3.22 & 11.76 & 85.02 \\
\hline$L 3 / 3$ & 206.561 & 0.98 & 14.28 & 0.49 & 0.25 & 38.40 & 3.53 & 14.58 & 81.88 \\
\hline $\mathrm{L} 3 / 4$ & 206.640 & 0.97 & 11.56 & 0.41 & 0.32 & 36.72 & 3.23 & 12.59 & 84.19 \\
\hline $\mathrm{L} 3 / 5$ & 206.699 & 0.98 & 17.33 & 1.91 & 0.77 & 31.84 & 14.93 & 11.87 & 73.19 \\
\hline L3/6 & 206.766 & 0.92 & 18.77 & 2.20 & 0.95 & 30.27 & 17.37 & 12.29 & 70.34 \\
\hline $\mathrm{L} 3 / 7$ & 206.800 & 0.97 & 15.85 & 1.77 & 0.62 & 34.43 & 13.33 & 10.35 & 76.31 \\
\hline L3/M/1 & 206.829 & 0.76 & 29.12 & 5.33 & 1.77 & 24.23 & 39.38 & 7.94 & 52.68 \\
\hline $\mathrm{L} 3 / \mathrm{M} / 2$ & 206.922 & 0.80 & 21.90 & 3.37 & 1.38 & 26.71 & 26.98 & 10.06 & 62.97 \\
\hline L4/1 & 207.000 & 0.75 & 17.96 & 2.33 & 0.74 & 35.26 & 16.62 & 9.46 & 73.92 \\
\hline$L 4 / 2$ & 207.059 & 0.85 & 14.52 & 1.18 & 0.48 & 35.07 & 9.01 & 12.01 & 78.98 \\
\hline$L 4 / 3$ & 207.176 & 0.86 & 16.94 & 0.70 & 0.31 & 38.14 & 4.95 & 16.16 & 78.89 \\
\hline$L 4 / 4$ & 207.302 & 0.82 & 14.59 & 0.46 & 0.25 & 36.79 & 3.45 & 15.58 & 80.98 \\
\hline
\end{tabular}




\begin{tabular}{|c|c|c|c|c|c|c|c|c|c|}
\hline L4/5 & 207.361 & 0.83 & 15.35 & 0.37 & 0.25 & 37.97 & 2.69 & 16.43 & 80.88 \\
\hline L4/6 & 207.400 & 1.54 & 15.16 & 1.32 & 0.55 & 37.51 & 9.50 & 11.29 & 79.21 \\
\hline L4/M/1 & 207.428 & 0.73 & 27.60 & 4.25 & 1.46 & 24.13 & 32.90 & 12.19 & 54.91 \\
\hline $\mathrm{L} 4 / \mathrm{M} / 2$ & 207.465 & 0.78 & 25.48 & 3.47 & 1.49 & 25.29 & 27.35 & 13.99 & 58.66 \\
\hline $\mathrm{L} 4 / \mathrm{M} / 3$ & 207.520 & 0.86 & 22.21 & 2.72 & 1.23 & 24.58 & 23.20 & 15.04 & 61.76 \\
\hline L4/M/4 & 207.594 & 0.90 & 19.67 & 2.14 & 0.93 & 27.91 & 17.65 & 14.46 & 67.89 \\
\hline $\mathrm{L} 5 / 1$ & 207.636 & 0.93 & 16.46 & 0.87 & 0.61 & 36.16 & 6.40 & 15.44 & 78.16 \\
\hline $\mathrm{L} 5 / 2$ & 207.682 & 1.02 & 11.88 & 0.49 & 0.29 & 34.64 & 4.00 & 13.11 & 82.88 \\
\hline$L 5 / 3$ & 207.747 & 0.99 & 14.64 & 0.56 & 0.28 & 32.87 & 4.53 & 16.52 & 78.95 \\
\hline $\mathrm{L} 5 / 4$ & 207.849 & 0.99 & 8.57 & 0.63 & 0.41 & 39.33 & 4.81 & 7.36 & 87.84 \\
\hline $\mathrm{L} 5 / 5$ & 207.900 & 1.01 & 13.77 & 1.28 & 0.61 & 33.51 & 10.23 & 10.98 & 78.79 \\
\hline L44/1 & 251.573 & 1.47 & 10.17 & 0.27 & 0.23 & 39.14 & 2.05 & 11.19 & 86.76 \\
\hline $\mathrm{L} 44 / 2$ & 251.618 & 1.42 & 9.02 & 0.30 & 0.27 & 40.02 & 2.28 & 9.54 & 88.19 \\
\hline L44/3 & 251.681 & 1.42 & 10.68 & 0.44 & 0.27 & 37.72 & 3.39 & 11.17 & 85.44 \\
\hline L44/4 & 251.743 & 1.43 & 14.65 & 0.69 & 0.41 & 39.10 & 4.85 & 13.70 & 81.45 \\
\hline L44/5 & 251.792 & 1.41 & 11.92 & 0.53 & 0.41 & 38.78 & 3.88 & 11.80 & 84.32 \\
\hline L44/6A & 251.900 & 1.34 & $\mathrm{~N} / \mathrm{A}$ & $\mathrm{N} / \mathrm{A}$ & $\mathrm{N} / \mathrm{A}$ & N/A & $\mathrm{N} / \mathrm{A}$ & $\mathrm{N} / \mathrm{A}$ & $\mathrm{N} / \mathrm{A}$ \\
\hline L44/6B & 251.910 & 1.38 & 10.67 & 0.54 & 0.40 & 35.03 & 4.39 & 11.30 & 84.30 \\
\hline L44/M/1 & 252.091 & 1.26 & 25.42 & 5.69 & 1.98 & 22.60 & 45.37 & 1.67 & 52.96 \\
\hline L45/1 & 252.306 & 1.25 & 14.01 & 0.46 & 0.31 & 37.66 & 3.41 & 14.68 & 81.91 \\
\hline $\mathrm{L} 45 / 2$ & 252.496 & 1.20 & 14.21 & 0.21 & 0.25 & 35.62 & 1.64 & 17.03 & 81.34 \\
\hline$L 45 / 3$ & 252.565 & 1.26 & 13.58 & $\mathrm{~N} / \mathrm{A}$ & 0.31 & 36.67 & $\mathrm{~N} / \mathrm{A}$ & 17.17 & 82.83 \\
\hline L45/4 & 252.614 & 1.21 & 13.35 & 0.30 & 0.28 & 36.31 & 2.34 & 15.32 & 82.34 \\
\hline $\mathrm{L} 45 / 5$ & 252.672 & 1.19 & 13.84 & 0.51 & 0.46 & 33.41 & 4.14 & 15.70 & 80.16 \\
\hline L45/6 & 252.780 & 1.28 & 15.92 & 0.46 & 0.40 & 36.03 & 3.43 & 17.23 & 79.33 \\
\hline $\mathrm{L} 45 / \mathrm{M} / 1$ & 252.990 & 1.21 & 29.04 & 6.28 & 2.21 & 22.45 & 47.30 & 2.98 & 49.72 \\
\hline L46/1 & 253.148 & 1.23 & 15.46 & 0.55 & 0.31 & 33.65 & 4.34 & 17.16 & 78.49 \\
\hline L46/2 & 253.258 & 1.22 & 15.68 & 0.44 & 0.32 & 33.25 & 3.52 & 18.21 & 78.26 \\
\hline$L 46 / 3$ & 253.353 & 1.21 & 14.22 & 0.36 & 0.33 & 32.38 & 2.97 & 17.49 & 79.55 \\
\hline L46/4 & 253.426 & 1.20 & 16.55 & 1.17 & 0.48 & 36.42 & 8.45 & 13.86 & 77.69 \\
\hline L46/5 & 253.500 & 1.16 & 15.52 & 1.46 & 0.68 & 32.20 & 11.67 & 12.35 & 75.98 \\
\hline L46/M/1 & 254.012 & 1.07 & 22.45 & 4.16 & 1.60 & 24.45 & 34.28 & 6.50 & 59.22 \\
\hline L47/1 & 254.304 & 1.21 & 16.68 & 0.43 & 0.27 & 34.53 & 3.28 & 18.79 & 77.93 \\
\hline $\mathrm{L} 47 / 2$ & 254.450 & 1.22 & 15.70 & 0.28 & 0.26 & 35.25 & 2.13 & 18.34 & 79.52 \\
\hline L47/3 & 254.640 & 1.18 & 16.25 & 0.37 & 0.28 & 35.21 & 2.78 & 18.42 & 78.80 \\
\hline
\end{tabular}




\section{APPENDIX C: NZ Timescale}
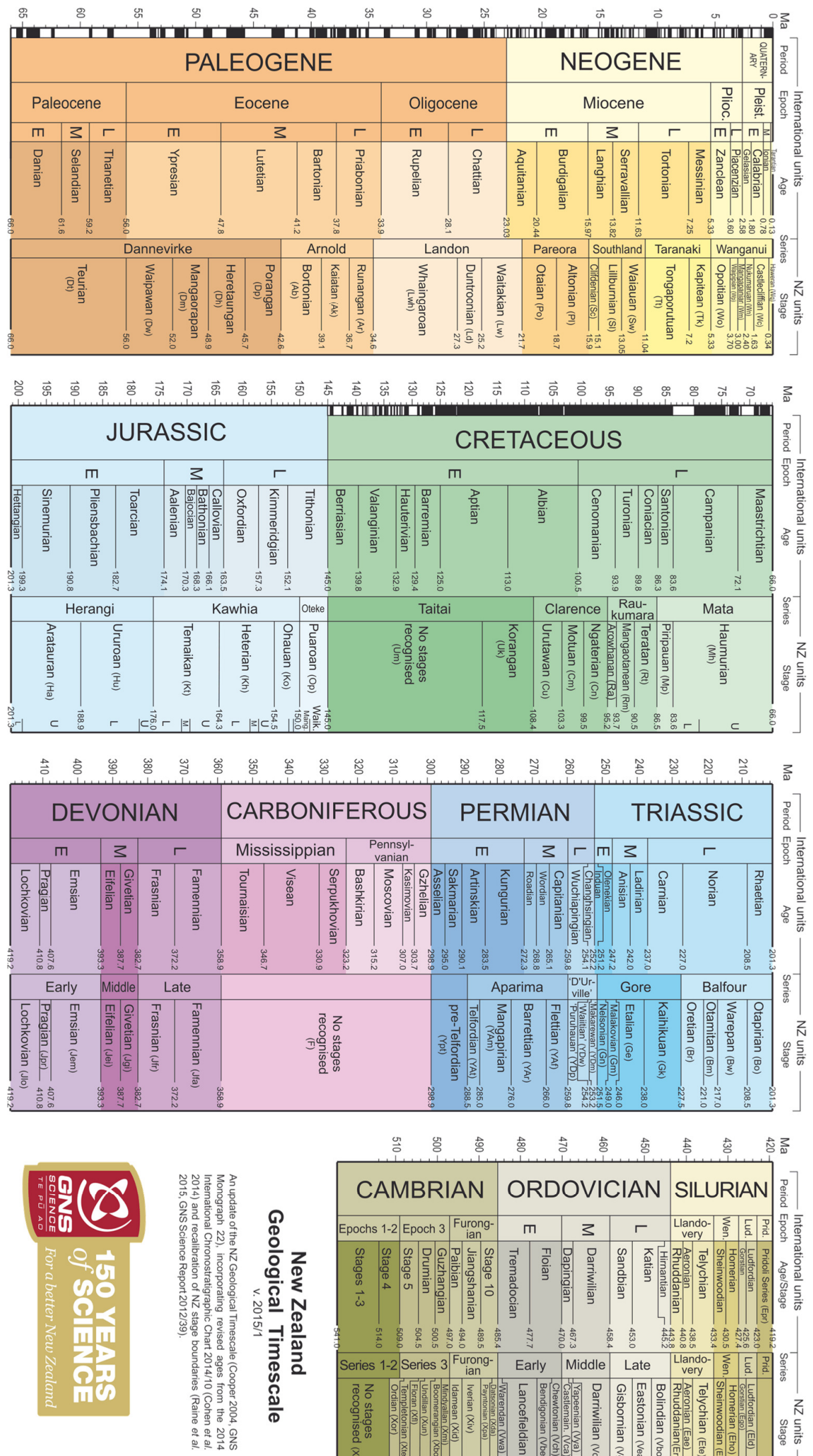

() Institute of Geological and Nuclear Sciences Ltd. 2015

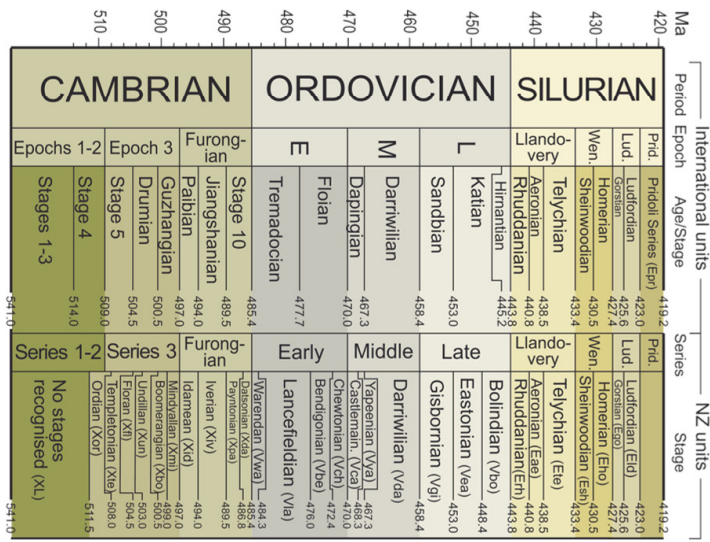

